\section{Pacific Northwest}

National Laboratory

Operated by Battelle for the

U.S. Department of Energy

\title{
Dust Plume Modeling at Fort Bliss: Full Training Scenario
}

(Contract No. 50026A)

E. G. Chapman

J. P. Rishel

F. C. Rutz

T. E. Seiple

R. K. Newsom

K. J. Allwine

September 2006

Prepared for the U. S. Army Fort Bliss Directorate of Environment under a Related Services Agreement with the U.S. Department of Energy under contract DE-AC05-76RL01830. 


\title{
DISCLAIMER
}

This report was prepared as an account of work sponsored by an agency of the United States Government. Neither the United States Government nor any agency thereof, nor Battelle Memorial Institute, nor any of their employees, makes any warranty, express or implied, or assumes any legal liability or responsibility for the accuracy, completeness, or usefulness of any information, apparatus, product, or process disclosed, or represents that its use would not infringe privately owned rights. Reference herein to any specific commercial product, process, or service by trade name, trademark, manufacturer, or otherwise does not necessarily constitute or imply its endorsement, recommendation, or favoring by the United States Government or any agency thereof, or Battelle Memorial Institute. The views and opinions of authors expressed herein do not necessarily state or reflect those of the United States Government or any agency thereof.

\author{
PACIFIC NORTHWEST NATIONAL LABORATORY \\ operated by \\ BATTELLE \\ for the \\ UNITED STATES DEPARTMENT OF ENERGY \\ under Contract DE-ACO5-76RL01830
}

Printed in the United States of America
Available to DOE and DOE contractors from the
Office of Scientific and Technical Information,
P.O. Box 62, Oak Ridge, TN 37831-0062;
ph: (865) 576-8401
fax: (865) 5765728
email: reports@adonis.osti.gov

\footnotetext{
Available to the public from the National Technical Information Service, U.S. Department of Commerce, 5285 Port Royal Rd., Springfield, VA 22161 ph: (800) 553-6847 fax: (703) 605-6900

email: orders@nits.fedworld.gov online ordering: http://www.ntis.gov/ordering.htm
} 


\title{
Dust Plume Modeling at Fort Bliss: Full Training Scenario
}

(Contract No. 50026A)

\author{
E. G. Chapman \\ J. P. Rishel \\ F. C. Rutz \\ T. E. Seiple \\ R. K. Newsom \\ K. J. Allwine
}

September 2006

Prepared for the U. S. Army Fort Bliss Directorate of Environment under a Related Services Agreement with the U.S. Department of Energy under contract DE-AC05-76RL01830.

Pacific Northwest National Laboratory

Richland, Washington 99352 


\section{Summary}

The potential for air-quality impacts from heavy mechanized vehicles operating in the training ranges and on the unpaved main supply routes at Fort Bliss is being investigated. The investigation uses the atmospheric modeling system DUSTRAN to simulate dust emission and dispersion from typical activities occurring on the installation. This report conveys the results of DUSTRAN simulations conducted using a "Full Training" scenario developed by Fort Bliss personnel. The Full Training scenario includes simultaneous off-road activities of two full heavy brigade combat teams (HBCTs) and one HBCT battalion on three training ranges. Simulations were conducted for the 6-day period, April 25-30, 2005, using previously archived meteorological records. Simulation results are presented in the form of 24-hour average $\mathrm{PM}_{10}$ plots and peak 1-hour $\mathrm{PM}_{10}$ concentration plots, where the concentrations represent contributions resulting from the specified military vehicular activities, not total ambient $\mathrm{PM}_{10}$ concentrations.

Results indicate that the highest 24-hour average $\mathrm{PM}_{10}$ contribution concentrations from vehicular activity occurred on April 30 when winds were light and variable. Under such conditions, particulates generated by vehicular movement stay in the area of generation and are not readily dispersed. The effect of training duration was investigated by comparing simulations with vehicular activity extending over a 10-hour period (0700 to $1700 \mathrm{MST}$ ) with simulations where vehicular activity was compressed into a 1-hour period (0700 to $0800 \mathrm{MST}$ ). Compressing all vehicular activity into 1 hour led to higher peak 1-hour and 24-hour average concentration contributions. The highest concentration contributions generally were near the Dona Ana Training Area. This area corresponds to the training region with the highest vehicle density (most vehicles per unit area) in the Full Training scenario. 



\section{Acronyms}

$\begin{array}{ll}\text { BRAC } & \text { base realignment and closure } \\ \text { DoD } & \text { U.S. Department of Defense } \\ \text { GIS } & \text { Geographical Information System } \\ \text { HBCT } & \text { heavy brigade combat team } \\ \text { kph } & \text { km per hour } \\ \text { PNNL } & \text { Pacific Northwest National Laboratory } \\ \text { PSD } & \text { prevention of significant deterioration } \\ \text { SERDP } & \text { Strategic Environmental Research and Development Program }\end{array}$ 



\section{Contents}

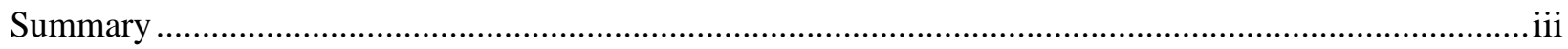

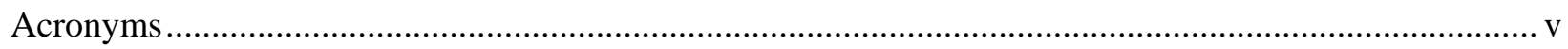

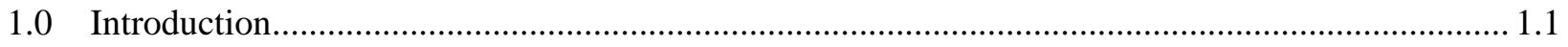

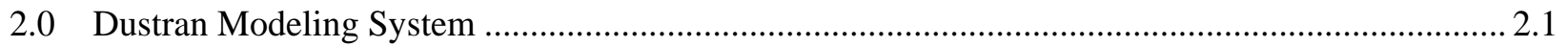

3.0 Specified Scenario and Implementation Within Dustran............................................................. 3.1



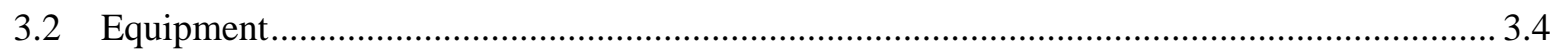

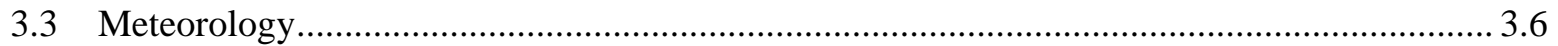



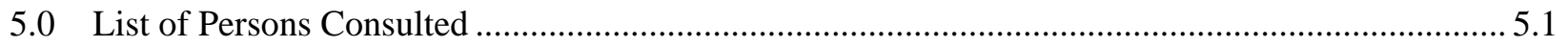

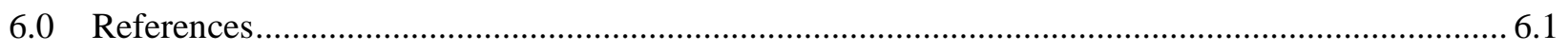

Appendix A: Mapping of Heavy Brigade Combat Team Vehicles to Dustran Vehicle Types.............. A.1

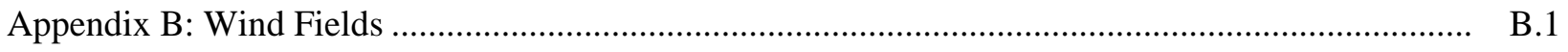

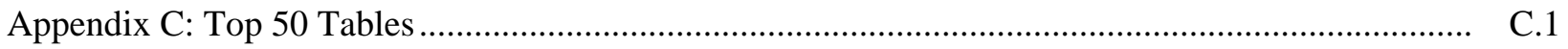




\section{Figures}

3.1. Training Area Locations Provided by Ft. Bliss Personnel ........................................................... 3.2

3.2. Modeling Domain and Location of Combat Training Areas and Subareas Used for the DUSTRAN Full Combat Training Scenario ............................................................................. 3.3

3.3. Location of Meteorological Stations Used in the Current Simulations ......................................... 3.8

4.1. Predicted 24-Hour Average $\mathrm{PM}_{10}$ Concentration Contributions: DUSTRAN Simulation of the Full Training Scenario (10 Hour Vehicular Activity Duration) for April 25, 2005

4.2. Predicted Peak 1-Hour $\mathrm{PM}_{10}$ Concentration Contributions: DUSTRAN Simulation of the Full Training Scenario (10 Hour Vehicular Activity Duration), 0700-0800 MST, April 25, 2005.

4.3. Predicted 24-Hour Average $\mathrm{PM}_{10}$ Concentration Contributions: DUSTRAN Simulation of the Full Training Scenario (10-Hour Vehicular Activity Duration) for April 26, 2005.

4.4. Predicted Peak 1-Hour $\mathrm{PM}_{10}$ Concentration Contributions: DUSTRAN Simulation of the Full Training Scenario (10-Hour Vehicular Activity Duration), 0800-0900 MST, April 26, 2005...... 4.7

4.5. Predicted 24-Hour Average $\mathrm{PM}_{10}$ Concentration Contributions: DUSTRAN Simulation of the Full Training Scenario (10-Hour Vehicular Activity Duration) for April 27, 2005.

4.6. Predicted Peak 1-Hour $\mathrm{PM}_{10}$ Concentration Contributions: DUSTRAN Simulation of the Full Training Scenario (10-Hour Vehicular Activity Duration), 0800-0900 MST, April 27, 2005....... 4.9

4.7. Predicted 24-Hour Average $\mathrm{PM}_{10}$ Concentration Contributions: DUSTRAN Simulation of the Full Training Scenario (10-Hour Vehicular Activity Duration) for April 28, 2005.

4.8. Predicted Peak 1-Hour $\mathrm{PM}_{10}$ Concentration Contributions: DUSTRAN Simulation of the Full Training Scenario (10-Hour Vehicular Activity Duration), 0700-0800 MST, April 28, 2005..... 4.11

4.9. Predicted 24-Hour Average $\mathrm{PM}_{10}$ Concentration Contributions: DUSTRAN Simulation of the Full Training Scenario (10-Hour Vehicular Activity Duration) for April 29, 2005.

4.10. Predicted Peak 1-Hour $\mathrm{PM}_{10}$ Concentration Contributions: DUSTRAN Simulation of the Full Training Scenario (10 Hour Vehicular Activity Duration), 0700-0800 MST, April 29, 2005 ..... 4.13

4.11. Predicted 24-Hour Average $\mathrm{PM}_{10}$ Concentration Contributions: DUSTRAN Simulation of the Full Training Scenario (10-Hour Vehicular Activity Duration) for April 30, 2005.

4.12. Predicted Peak 1-Hour $\mathrm{PM}_{10}$ Concentration Contributions: DUSTRAN Simulation of the Full Training Scenario (10-Hour Vehicular Activity Duration), 0700-0800 MST, April 30, 2005 ..... 4.15

4.13. Predicted 24-Hour Average $\mathrm{PM}_{10}$ Concentration Contributions: DUSTRAN Simulation of the Full Training Scenario (1-Hour Vehicular Activity Duration) for April 25, 2005. 4.16

4.14. Predicted Peak 1-Hour $\mathrm{PM}_{10}$ Concentration Contributions: DUSTRAN Simulation of the Full 
Training Scenario (1-Hour Vehicular Activity Duration), 0700-0800 MST, April 25, 2005....... 4.17

4.15. Predicted 24-Hour Average $\mathrm{PM}_{10}$ Concentration Contributions: DUSTRAN Simulation of the Full Training Scenario (1-Hour Vehicular Activity Duration) for April 26, 2005.

4.16. Predicted Peak 1-Hour $\mathrm{PM}_{10}$ Concentration Contributions: DUSTRAN Simulation of the Full Training Scenario (1-Hour Vehicular Activity Duration), 0700-0800 MST, April 26, 2005....... 4.19

4.17. Predicted 24-Hour Average $\mathrm{PM}_{10}$ Concentration Contributions: DUSTRAN Simulation of the Full Training Scenario (1-Hour Vehicular Activity Duration) for April 27, 2005.

4.18. Predicted Peak 1-Hour $\mathrm{PM}_{10}$ Concentration Contributions: DUSTRAN Simulation of the Full Training Scenario (1-Hour Vehicular Activity Duration), 0700-0800 MST, April 27, 2005...... 4.21

4.19. Predicted 24-Hour Average $\mathrm{PM}_{10}$ Concentration Contributions: DUSTRAN Simulation of the Full Training Scenario (1-Hour Vehicular Activity Duration) for April 28, 2005.

4.20. Predicted Peak 1-Hour $\mathrm{PM}_{10}$ Concentration Contributions: DUSTRAN Simulation of the Full Training Scenario (1-Hour Vehicular Activity Duration), 0700-0800 MST, April 28, 2005....... 4.23

4.21. Predicted 24-Hour Average $\mathrm{PM}_{10}$ Concentration Contributions: DUSTRAN Simulation of the Full Training Scenario (1-Hour Vehicular Activity Duration) for April 29, 2005.

4.22. Predicted Peak 1-Hour $\mathrm{PM}_{10}$ Concentration Contributions: DUSTRAN Simulation of the Full Training Scenario (1-Hour Vehicular Activity Duration), 0700-0800 MST, April 29, 2005...... 4.25

4.23. Predicted 24-Hour Average $\mathrm{PM}_{10}$ Concentration Contributions: DUSTRAN Simulation of the Full Training Scenario (1-Hour Vehicular Activity Duration) for April 30, 2005. 4.26

4.24. Predicted Peak 1-Hour $\mathrm{PM}_{10}$ Concentration Contributions: DUSTRAN Simulation of the Full Training Scenario (1-Hour Vehicular Activity Duration), 0700-0800 MST, April 30, 2005.

4.25. Comparison of Predicted Peak 1-Hour $\mathrm{PM}_{10}$ Concentration Contributions for 0700-0800 MST, April 25, 2005: 1-Hour Vehicular Activity Duration (left) and 10-Hour Vehicular Activity Duration (right).

4.26. Comparison of Predicted 24-Hour PM10 Concentration Contributions for April 25, 2005 : 1-Hour Vehicular Activit Duration (left) and 10-Hour Vehicular Activity Duration (right)

4.27. Comparison of Predicted 24-Hour $\mathrm{PM}_{10}$ Concentration Contributions for April 30, 2005: 1-Hour Vehicular Activity Duration (left) and 10-Hour Vehicular Activity Duration (right) ...... 4.30

\section{Tables}

3.1. Overall Mapping of All Heavy Brigade Combat Team Vehicles to DUSTRAN Vehicle Types.... 3.4

3.2. Information on Meteorological Stations Used in Current Simulations 3.7 


\subsection{Introduction}

Fort Bliss is a multi-mission United States Army installation covering approximately 1.12 million acres stretching over parts of Texas and New Mexico. The Fort Bliss Training Complex covers the vast majority of the installation land area and is composed of three large geographic segments - the South Training Area, the Dona Ana Range-North Training Area, and the McGregor Range. Recent recommendations by the Base Realignment and Closure (BRAC) Commission will lead to additional personnel and equipment being assigned to Fort Bliss. These recommendations also may require increasing land areas available for off-road training and maneuver. Dust emissions from military activities on both established and newly opened training areas have the potential to move off the installation and impact air quality in the local air shed.

Pacific Northwest National Laboratory (PNNL) has been conducting general studies of the potential for air quality impacts from heavy mechanized vehicles operating in the training ranges and on the unpaved main supply routes at Fort Bliss for the Fort Bliss Air Program Manager. These studies have involved setting up and using the atmospheric modeling system DUSTRAN to simulate dust emission and dispersion from typical vehicular activities occurring on the installation. Preliminary results of these general studies were communicated to the Fort Bliss Air Program manager in a draft May 16, 2006, interim report (Chapman et al. 2006, personal communication to J. Moncada, Fort Bliss Air Program Manager).

As a result of the draft interim report, Fort Bliss staff requested that PNNL staff use the DUSTRAN modeling system to simulate a specific combat training scenario. This specific scenario, defined by Fort Bliss staff, includes simultaneous off-road activities on all three major training ranges and is referred to as the "Full Training" scenario. The purpose of this report is to convey the results of simulations conducted using the Full Training scenario. We begin by briefly describing the DUSTRAN modeling system and summarizing model-relevant parameters associated with the Full Training scenario. Results of simulations conducted using the Full Training scenario, in the form of 24-hour average $\mathrm{PM}_{10}$ plots and peak 1-hour $\mathrm{PM}_{10}$ concentration plots, are presented and briefly discussed. 


\subsection{Dustran Modeling System}

DUSTRAN was developed under the U.S. Department of Defense's (DoD’s) Strategic Environmental Research and Development Program (SERDP) to create an atmospheric dispersion modeling system to assist the DoD in addressing particulate air quality issues at military training and testing ranges (Allwine et al. 2004; Allwine et al. 2006). DUSTRAN is a comprehensive dispersion modeling system that is integrated into ESRI’s ArcMap Geographical Information System (GIS) software. It consists of a diagnostic meteorological model, an emissions model, and a dispersion model. DUSTRAN functions as a console application within ArcMap and allows the user to interactively create a release scenario and execute the underlying models. Using data layering, the model domain, sources, and results-including the calculated wind vector field and plume contours — can be displayed with other spatial and geophysical data sources to aid in analyzing and interpreting the scenario.

The core components within DUSTRAN are the CALPUFF modeling system and a dust-emissions factor module. The CALPUFF modeling system is an EPA-approved (40 CFR Part 51, Appendix W) suite of models for simulating the effects of time- and space-varying meteorological conditions on pollution transport, transformation, and removal. Source-term information is generated by DUSTRAN's dustemission factors module, which contains factors for various wheeled military vehicles (Gillies et al. 2005a; 2005b) and incorporates the widely used AP-42 emission factors for paved and unpaved roadway surfaces (EPA 2005). The experiments to derive the Gillies et al. (2005a; 2005b) emission factors were conducted at Fort Bliss during the spring of 2001 and the spring of 2002.

The CALPUFF modeling system includes the CALMET meteorological model (Scire et al. 2000b) and the CALPUFF dispersion model (Scire et al. 2000a). In the most general sense, CALMET creates gridded fields of wind and boundary-layer parameters from observed meteorological data. These gridded fields are then supplied to CALPUFF, which performs the plume advection, deposition, and diffusion calculations. A second dispersion model, called CALGRID (Scire et al. 1989), is also integrated into DUSTRAN. CALGRID is useful for applications where source emissions can be characterized over a gridded area, such as the modeling of wind-blown dust, whereas CALPUFF is most applicable for discrete source emissions, such as from vehicular activity.

To simplify input data requirements, numerous data preprocessors interface CALMET, CALPUFF, and CALGRID to available terrain elevation and land-use datasets for use in model calculations. All the model components are dynamically linked by the DUSTRAN interface. For the current application, Fort Bliss Directorate of Environment staff provided relevant reference data layers (e.g., roads, tank trails, installation boundaries, training area locations). 


\subsection{Specified Scenario and Implementation Within Dustran}

Use of DUSTRAN to simulate dust emissions from vehicular activity in any scenario requires stipulation of 1) the location where the activity occurs, 2) equipment information in terms of the number and type of vehicles involved in the activity, along with information on the timing and duration of the activity, and 3) meteorological information.

\subsection{Location}

The combat training scenario specified by Fort Bliss staff involves the simultaneous use of three training areas. In the Full Training scenario, two full heavy brigade combat teams (HBCTs) operate in the Dona Ana and McGregor Ranges while one third of a HBCT (i.e., one battalion) operates in the South Training Area. The approximate locations and sizes of the three maneuver areas provided by Fort Bliss personnel are shown in Figure 3.1. The DUSTRAN representation of these areas is indicated in Figure 3.2.

Combat training activities such as those in the Full Training scenario are simulated as area sources in DUSTRAN. To facilitate more realistic plume production within the model, each of the three relatively large maneuver boxes is divided into subareas. The Dona Ana 1 Combat Training area is divided into four roughly square subareas (labeled “ $a$," “ $b$," “c," and “ $d$ ” in Figure 3.2). The South Combat Training area is divided into two subareas (labeled " $a$ " and " $b$ " in Figure 3.2). The McGregor Combat Training region is over three times larger than either the Dona Ana or South Training maneuver boxes and is divided into seven subareas (labeled “ $a$," " $b$," “c,” “ $d$," “e,” “ $f$,” and “ $g$ ” in Figure 3.2).

We note that the Dona Ana 1 and South Training areas shown in Figure 3.2 correspond to maneuver boxes previously used in our general simulation studies. The McGregor region, not previously simulated, is modified slightly from the region identified by Fort Bliss staff, as can be seen by comparing Figure 3.1 and Figure 3.2. For example, circular borders were made more angular. These modifications were driven by the fact that area sources within DUSTRAN must be defined by four-point polygons, making curved edges difficult to mimic. The "stair step" boundary pattern in the northeastern part of the McGregor Range also was smoothed because including the "steps" would lead to multiple small subareas that vary by orders of magnitude in size from other subareas. Within the constraints of DUSTRAN polygondefinition algorithms, we tried to mimic the overall extent of the indicated McGregor region as closely as possible. 


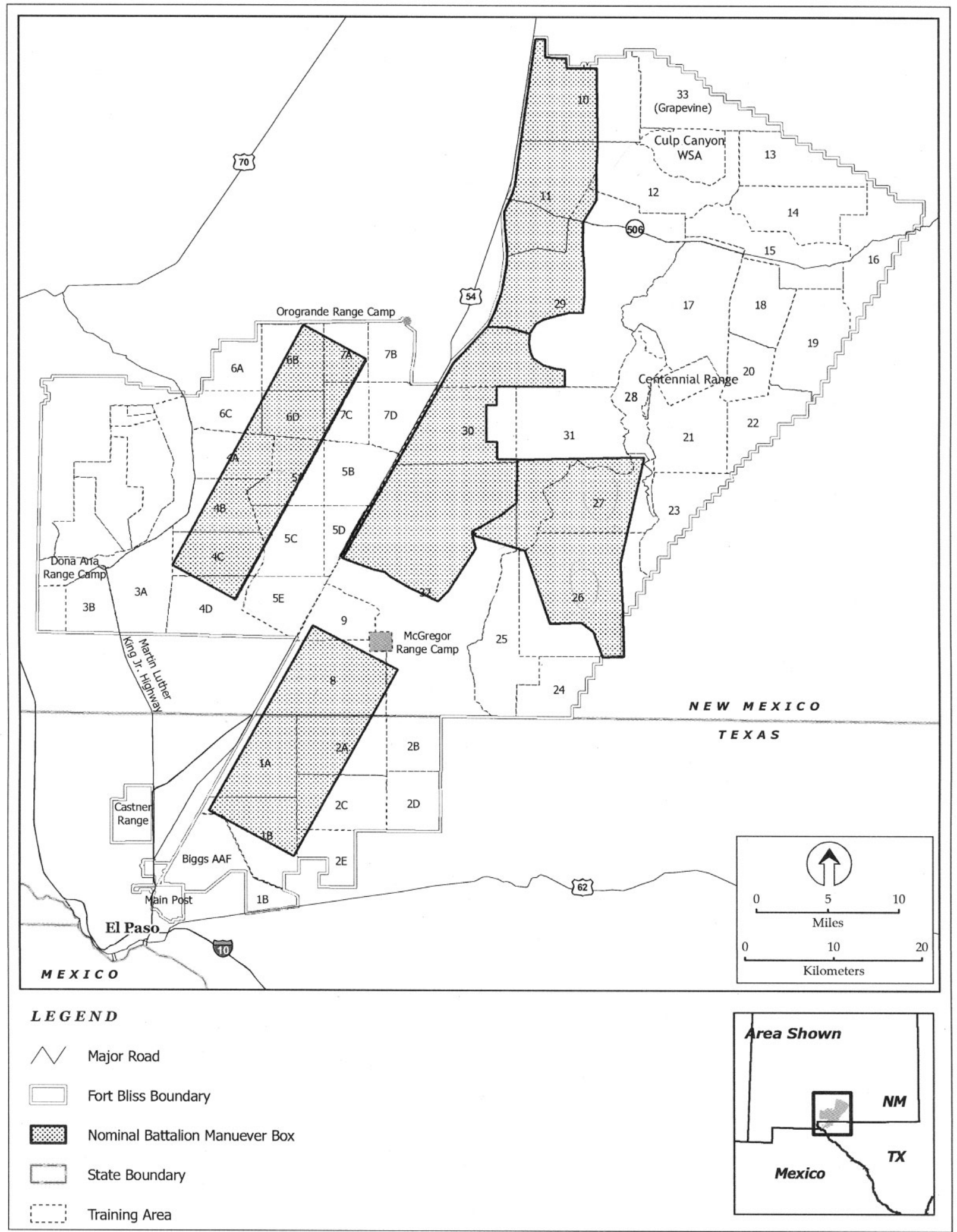

Figure 3.1. Training Area Locations Provided by Ft. Bliss Personnel 


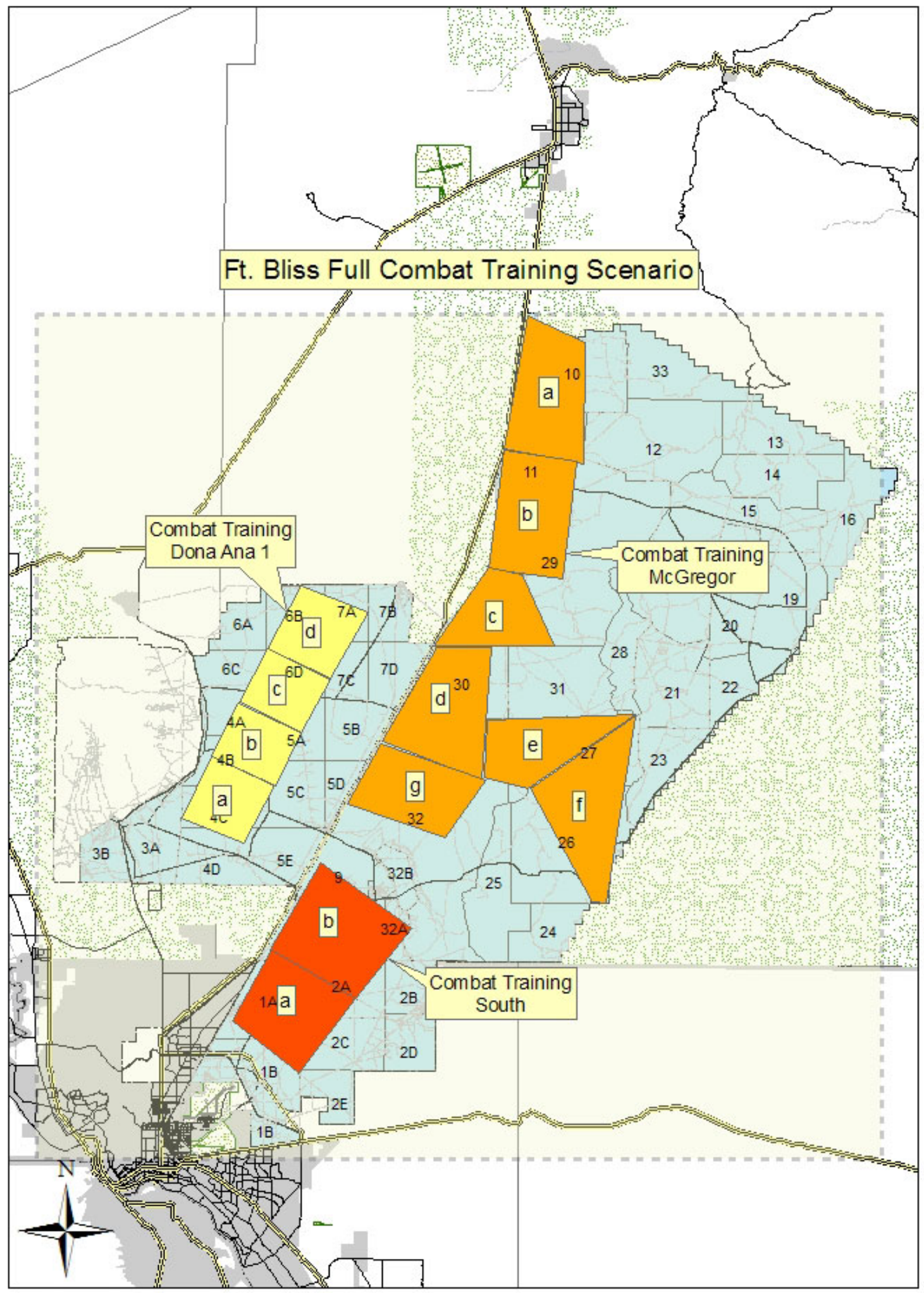

Figure 3.2. Modeling Domain and Location of Combat Training Areas and Subareas Used for the DUSTRAN Full Combat Training Scenario 


\subsection{Equipment}

According to a report entitled "Prevention of Significant Deterioration (PSD) Analysis" and an accompanying Excel spreadsheet (Booz Allen Hamilton 2005), previously provided by Fort Bliss staff, one HBCT consists of 758 wheeled and 354 tracked vehicles. Vehicles associated with a HBCT were mapped to available DUSTRAN vehicle types via the mapping process used in our previous general studies. The mapping process uses vehicle descriptions and weight as the major mapping criteria. Information in the Booz Allen Hamilton report and spreadsheet (2005) served as the basis for this mapping. Table A.1 of Appendix A indicates the assigned mapping of individual HBCT vehicles, as given in the Booz Allen Hamilton spreadsheet, to individual DUSTRAN vehicle types. Table 3.1 summarizes the overall mapping of all vehicles in a single HBCT to DUSTRAN vehicle types. Note that the 758 wheeled vehicles present in an HBCT are mapped to a total of 758 wheeled DUSTRAN vehicles, while the 354 tracked vehicles present in an HBCT are mapped to a total of 548 DUSTRAN vehicles. The number of DUSTRAN vehicles representing tracked vehicles is larger than the actual HBCT total because in some instances, the tracked vehicles are heavier than representative DUSTRAN vehicle types and must be mapped as multiple DUSTRAN vehicles (see Appendix A). Vehicles were apportioned among the subareas using an areal weighting. For example, Dona Ana 1 subarea " $d$ " contains $28.5 \%$ of the area associated with the full Dona Ana 1 Training Area. Subarea " $d$ " was therefore assigned 28.5\% of the total number of each vehicle type operating in Dona Ana 1 (to the nearest whole vehicle; DUSTRAN does not accept fractional vehicle numbers). This process is consistent with the assumption of uniform vehicle distribution and density throughout each training area.

Table 3.1. Overall Mapping of All Heavy Brigade Combat Team Vehicles to DUSTRAN Vehicle Types

\begin{tabular}{|c|c|c|c|c|c|c|}
\hline & HMMWV & $\begin{array}{c}\text { GMC } \\
\text { G20 VAN }\end{array}$ & $\begin{array}{l}\text { GMC } \\
\text { C550 }\end{array}$ & $\begin{array}{l}\text { M923A2 } \\
\text { (5-TON) }\end{array}$ & $\begin{array}{c}\text { M977 } \\
\text { HEMMET }\end{array}$ & $\begin{array}{c}\text { LOADED } \\
\text { FREIGHTLINER }\end{array}$ \\
\hline Mapping of Wheeled & & & & & & \\
\hline $\begin{array}{l}\text { HBCT Vehicles } \\
\text { Mapping of Tracked }\end{array}$ & 562 & 55 & 24 & 102 & 0 & 15 \\
\hline HBCT Vehicles & 0 & 0 & 0 & 63 & 35 & 450 \\
\hline Total & 562 & 55 & 24 & 165 & 35 & 465 \\
\hline
\end{tabular}

Using vehicle weight to perform the mapping is consistent with the findings of Gillies et al. (2005a; 2005b). They observed that vehicle weight and vehicle speed are the only two variables that matter significantly in calculating $\mathrm{PM}_{10}$ military wheeled-vehicle emission factors for unpaved roads. We note that DUSTRAN calculations are relatively insensitive to the exact DUSTRAN vehicle chosen for use in a particular military vehicle mapping as long as the overall military vehicle weight is approximated. For example, consider a situation where 50 military vehicles weighing 10,000 kg each must be mapped to available DUSTRAN vehicles. The total weight of 500,000 kg is approximately equal to 21 freightliners loaded with Patriot missile batteries, each weighing 23,636 kg. (As noted previously, DUSTRAN does not allow fractional vehicle numbers.) To simulate the effects of these fifty 10,000-kg vehicles, 21 "Loaded Freightliners" thus could be entered into DUSTRAN. The 21 "Loaded Freightliners" would yield a total weight of $496,356 \mathrm{~kg}$, a difference of $0.7 \%$ from the true weight of 500,000 kg. Alternatively, if the weight of an unloaded freightliner $(8,982 \mathrm{~kg})$ were used for the mapping, 56 "Unloaded Freightliners" could be entered into DUSTRAN to represent the fifty 10,000-kg vehicles. The 56 "Unloaded Freightliners" would yield a total weight of 502,992 kg, a difference of $0.6 \%$ from the 
true weight of 500,000 kg. Because of the linear nature of the Gilles et al. (2005a; 2005b) equations, a small difference from "true" weight will carry through the calculations and cause a comparable difference in calculated source strength. In this example, entering 21 "Loaded Freightliners" would yield a source strength $0.7 \%$ lower than the "true" best estimate source strength, while entering 56 "Unloaded Freightliners" would yield a source strength $0.6 \%$ higher than the "true” best estimate source strength. Such small differences will have a negligible effect on DUSTRAN concentration contours.

In brief, the mapping process allows vehicles currently included in DUSTRAN to be used as surrogates for other vehicles. If a lighter vehicle type is chosen as the surrogate, a greater numbers of vehicles will be entered than if a heavier vehicle type had been chosen as the surrogate.

DUSTRAN also requires information on vehicle speeds, travel distances, and timing of the vehicular activity. A vehicle speed of $40 \mathrm{~km}$ per hour ( $\mathrm{kph}$ ) was assigned to all vehicle types in the Full Training scenario. This rate corresponds to speeds used in combat training scenarios previously modeled in our general studies. Fort Bliss staff indicated that military training guidelines suggest that wheeled vehicles travel approximately 20 miles per day (equivalent to $32.2 \mathrm{~km}$ per day) while tracked vehicles travel approximately 13 miles per day (equivalent to $20.9 \mathrm{~km}$ per day) (Walter Christensen, personal communication to E. Chapman). Based on this information, within DUSTRAN, a total travel distance of $32 \mathrm{~km}$ per day per vehicle was assigned to all the HMMWV, GMC G20 Vans, and GMC C550 vehicles, and to 102 of the M923A2 (5-ton) and 15 loaded freightliner vehicles. A total travel distance of $21 \mathrm{~km}$ per day per vehicle was assigned to all the M977 HEMMET and to 63 of the M923A2 (5-ton) and 450 loaded freightliner vehicles. These assignments mirror the wheeled and tracked vehicle numbers given in Table 3.1.

For timing purposes, the 0700 MST start time used in our previous general studies was retained for the Full Training scenario. Fort Bliss staff requested that separate sets of simulations be conducted with vehicle movement occurring 1) uniformly over a 10-hour period from 0700 to 1700 MST and 2) concentrated into 1 hour. For reasons discussed later, simulations for the extreme case of vehicle movement concentrated into 1 hour were conducted with all movements assumed to occur from 0700 to 0800 MST.

Full Training scenario parameters discussed above are summarized below.

- All vehicles associated with one HBCT are located in the region labeled "Combat Training Dona Ana 1” in Figure 3.1.

- All vehicles associated with one HBCT are located in the region labeled "Combat Training McGregor” in Figure 3.1.

- Vehicles associated with one-third of an HBCT (i.e., one battalion) are located in the region labeled "Combat Training South" in Figure 3.1.

- Within each training area and subarea, uniform distributions of vehicle type and vehicle numbers exist.

- Vehicles are already located in the training areas when activities commence (i.e., no travel to training areas from the McGregor or Dona Ana Range Camps).

- All combat training begins at 0700 MST.

- Vehicle movement occurs uniformly over either 1) a 10-hour period or 2) a 1-hour period (two separate sets of simulations). For vehicle movement occurring over a 1-hour period, all 
movement occurs between 0700-0800 MST.

- The total distance traveled by each wheeled vehicle over the course of a training day is $32 \mathrm{~km}$, or approximately 20 miles.

- The total distance traveled by each tracked vehicle over the course of a training day is $21 \mathrm{~km}$, or approximately 13 miles.

- When moving, all vehicles travel at a speed of $40 \mathrm{~km}$ per hour.

As noted previously, DUSTRAN incorporates emission factors for various wheeled military vehicles as developed by Gillies et al. (2005a; 2005b). Dust-emission factors specific to tracked military vehicles do not currently exist. An assumption in the Full Training scenario simulations is that the emission factors for tracked military vehicles operating off road can be approximated by the emission factors for wheeled military vehicles traveling on unpaved roads. All DUSTRAN simulations conducted under the Full Training scenario used the wheeled military vehicle emission factors developed by Gillies et al. (2005a; 2005b).

\subsection{Meteorology}

Meteorological conditions influence the volume of air into which emissions are mixed and also affect the transport and deposition processes operating on the emitted material. DUSTRAN thus requires meteorological information as input, including wind speed and direction, temperature, cloud cover, surface pressure, and relative humidity.

In the previous general studies, PNNL staff analyzed the local wind climatology for the 4-year period, 2002-2005, to determine both seasonal and diurnal trends in the wind patterns. This information was then used to identify candidate periods for dispersion simulation. The candidate simulation periods for the general studies were selected based on an examination of surface and upper air data from 2005. Ideally, we wanted to find periods with continuous data records lasting several days from a distribution of monitoring stations over the modeling domain, periods that were also likely to be climatologically representative with respect to dust emissions. Four simulation periods were selected for use in the general studies, approximately spanning the periods March 12-17, April 24-May 1, July 20-25, and November 25-30, 2005. Meteorological data from stations listed in Table 3.2 and located as shown in Figure 3.3 were archived for these periods. The previous general studies concentrated on the April 24-May 1, 2005, dates because the spring period is usually dry, with particulate concentrations in the local airshed generally higher and of greater concern.

Simulations presented in this report were conducted using the previously archived hourly data from meteorological stations located as shown in Figure 3.3 for the period April 24-May 1, 2005, as requested by Fort Bliss staff. The simulations are based on actual meteorological conditions, not idealized cases, and represent a range of wind speeds and directions. 
Table 3.2. Information on Meteorological Stations Used in Current Simulations

\begin{tabular}{|c|c|c|c|}
\hline Station ID & Operator & Latitude & Longitude \\
\hline CAMS12 & $\mathrm{TCEQ}^{(\mathrm{a})}$ & -106.5011 & 31.7681 \\
\hline CAMS414 & TCEQ & -106.3242 & 31.7864 \\
\hline CAMS72 & TCEQ & -106.4258 & 31.8939 \\
\hline CAMS37 & TCEQ & -106.4028 & 31.7467 \\
\hline CAMS49 & TCEQ & -106.3031 & 31.6622 \\
\hline LOMN5 & RAWS $^{(\mathrm{b})}$ & -106.5867 & 32.3233 \\
\hline SNDN5 & RAWS & -106.5250 & 32.5800 \\
\hline WSMN5 & GPSMET $^{(\mathrm{c})}$ & -106.3500 & 32.4100 \\
\hline EPZ & $\mathrm{NWS}^{(\mathrm{d})}$ & -106.7000 & 31.9000 \\
\hline KALM & NWS & -105.9833 & 32.8333 \\
\hline KELP & NWS & -106.3758 & 31.8111 \\
\hline KLRU & NWS & -106.9219 & 32.2894 \\
\hline 60 & $\mathrm{NMED}^{(\mathrm{e})}$ & -106.6306 & 31.9306 \\
\hline $6 Z G$ & NMED & -106.5575 & 31.7958 \\
\hline 6ZL & NMED & -106.6742 & 32.4247 \\
\hline $6 Z K$ & NMED & -106.4092 & 32.0411 \\
\hline $6 Z M$ & NMED & -106.5839 & 31.7961 \\
\hline $6 Z N$ & NMED & -106.6828 & 31.7878 \\
\hline $6 \mathrm{WM}$ & NMED & -106.8644 & 32.2781 \\
\hline
\end{tabular}
(a) TCEQ = Texas Commission on Environmental Quality
(b) RAWS = Remote Automated Weather Station
(c) GPSMET = Global Positioning System Meteorology
(d) NWS = National Weather Service
(e) NMED = New Mexico Environment Department 


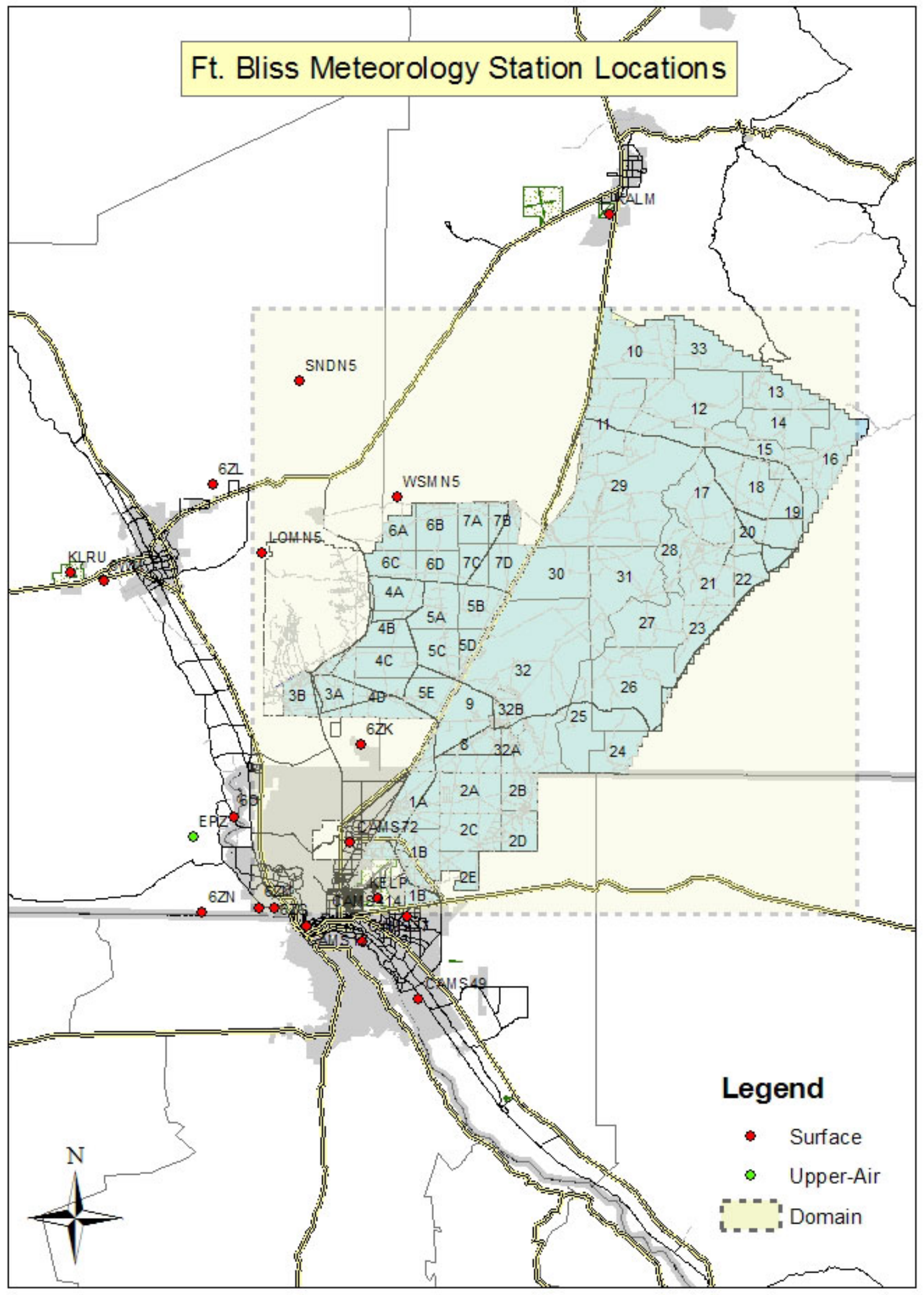

Figure 3.3. Location of Meteorological Stations Used in the Current Simulations 


\subsection{Results And Discussion}

All simulations were conducted on a 100-km $\times 100-\mathrm{km}$ domain encompassing the Fort Bliss installation (see Figure 3.2 and Figure 3.3). Individual grid cells were $2 \mathrm{~km} \times 2 \mathrm{~km}$ in horizontal extent with six vertical levels geometrically spaced to extend from the surface to 3300 meters. All simulations were initiated at midnight and ran for 24 hours. Available archived meteorology permitted full 24-hour simulations for 6 days; April 25, 26, 27, 28, 29, and 30. Appendix B contains screen captures of the 10-m above ground level wind fields predicted by the CALMET module within DUSTRAN at 0700, 1000, 1300, 1600, and 1900 MST for each of these days. These figures are useful for visualizing changes in wind speed and direction that occur throughout a given day and for discerning differences in wind speed and direction among the various days.

Figure 4.1 shows the predicted contribution of Full Training scenario activities to the 24-hour average surface $\mathrm{PM}_{10}$ concentration in micrograms per cubic meter $\left(\mu \mathrm{g} / \mathrm{m}^{3}\right)$ for April 25, 2005, when vehicular activities occur over the 10-hour period from 0700 to $1700 \mathrm{MST}$. Note that these predictions represent contributions resulting from the specified military vehicular activities, not total ambient $\mathrm{PM}_{10}$ concentrations. Background particulate concentrations in an incoming air mass and particulates generated via wind erosion and from disturbed soils also contribute to total ambient $\mathrm{PM}_{10}$ concentrations, but are not accounted for in these simulations. We refer to the model predictions as "concentration contributions" to emphasize this point.

Figure 4.2 is a screen capture of the predicted peak 1-hour average contributions to surface $\mathrm{PM}_{10}$ concentrations for April 25, i.e., a screen capture of the hour during which the highest single value of predicted contributions to surface $\mathrm{PM}_{10}$ concentrations occurred. Again, we emphasize that these values represent contributions to ambient $\mathrm{PM}_{10}$ levels from activities associated with the Full Training Scenario; they do not represent total ambient $\mathrm{PM}_{10}$ concentrations. For April 25, and for three other simulated days (April 28, 29, and 30), the highest single value contribution occurred between 0700-0800 MST, during the first hour of the vehicular activity. On the remaining 2 days (April 26 and 27), the highest single value concentration contribution occurred 1 hour later, between 0800-0900 MST. These results are consistent with meteorological expectations. Early in the morning, the atmosphere is generally more stable and the boundary layer more shallow than in the afternoon. Early-morning surface emissions thus can be released into a smaller volume of air with less turbulent mixing than comparable late-morning or afternoon emissions. This situation automatically leads to higher concentrations. 


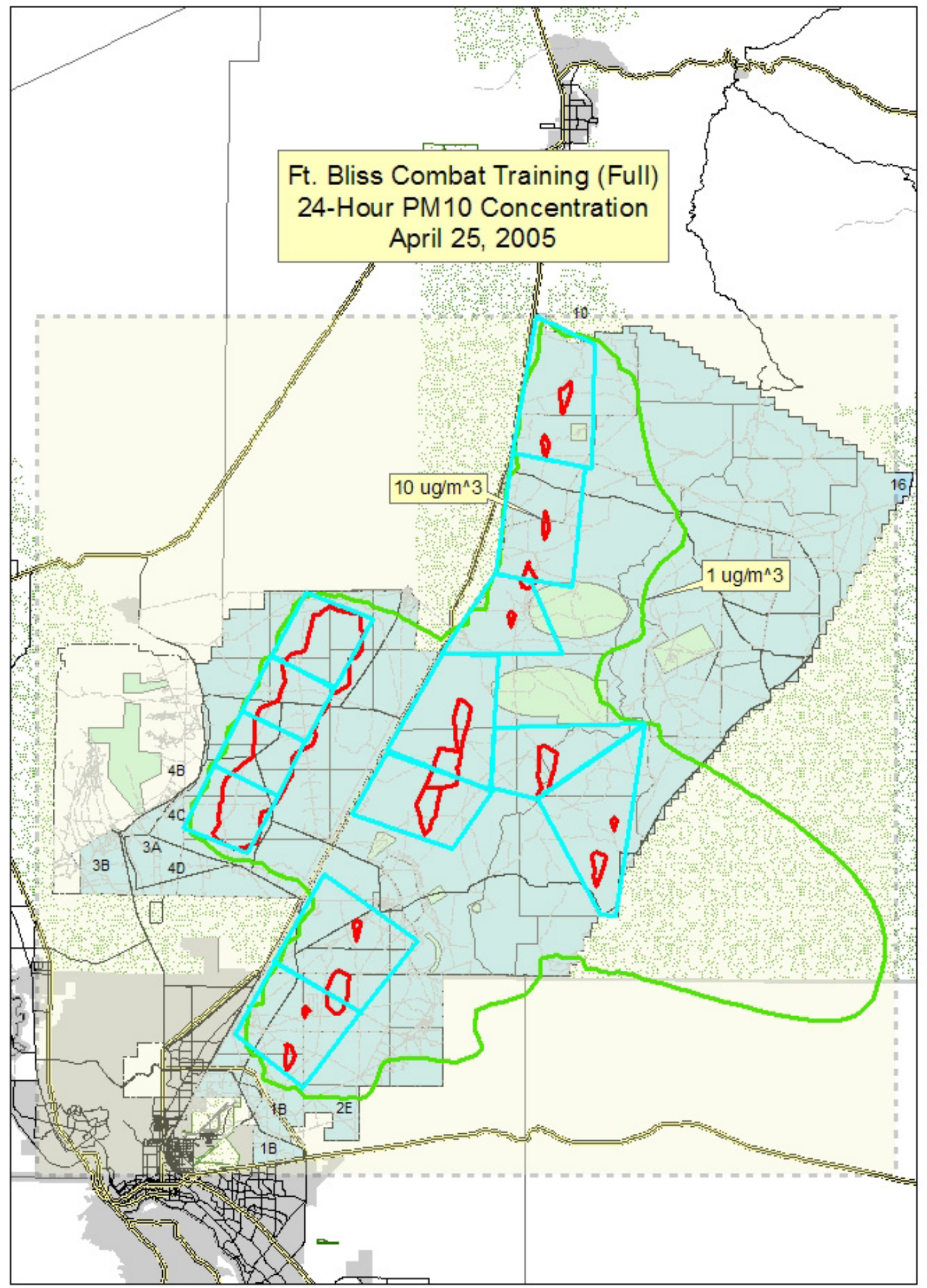

Figure 4.1. Predicted 24-Hour Average $\mathbf{P M}_{10}$ Concentration Contributions: DUSTRAN Simulation of the Full Training Scenario (10 Hour Vehicular Activity Duration) for April 25, 2005 


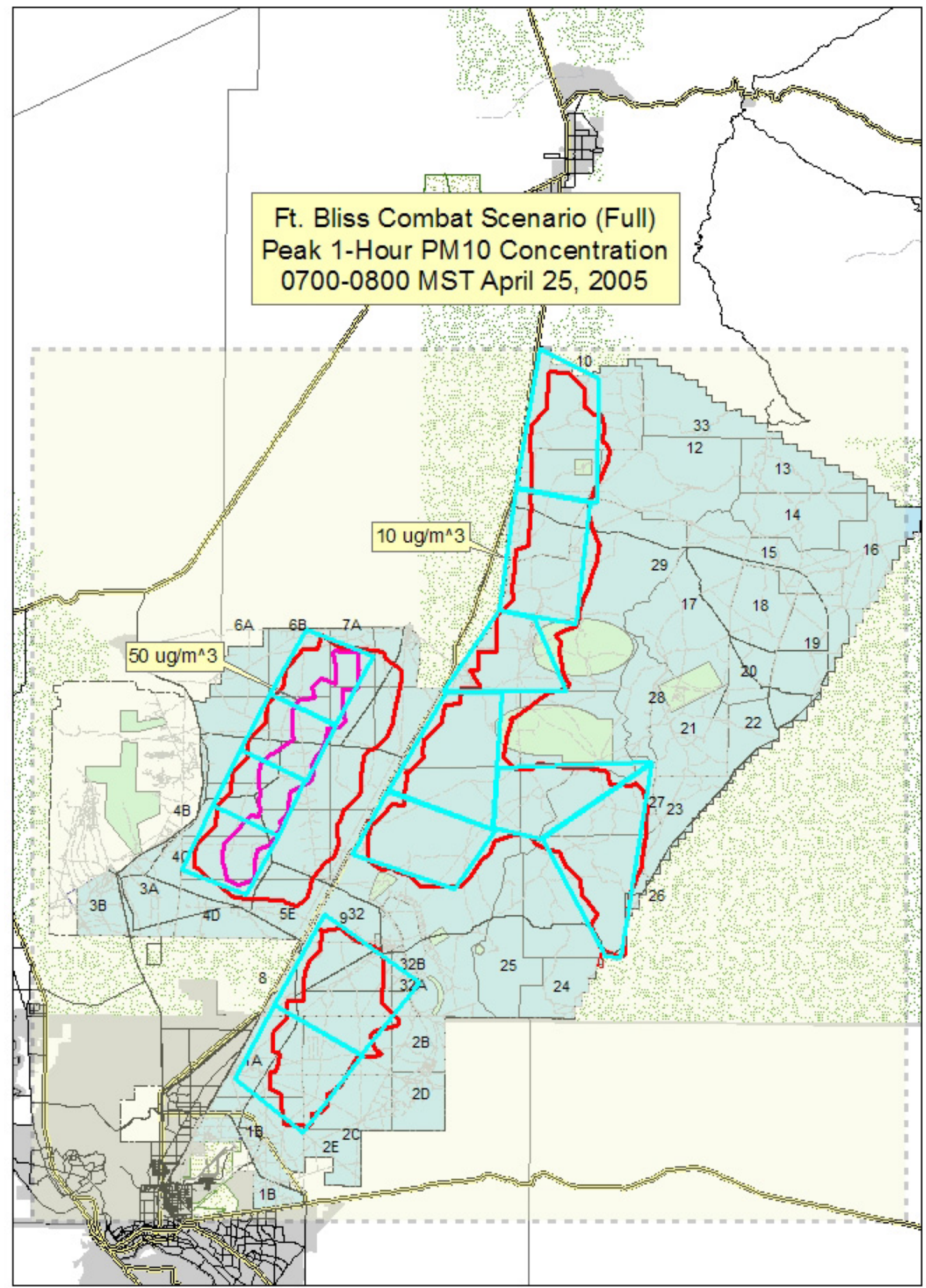

Figure 4.2. Predicted Peak 1-Hour $\mathrm{PM}_{10}$ Concentration Contributions: DUSTRAN Simulation of the Full Training Scenario (10 Hour Vehicular Activity Duration), 0700-0800 MST, April 25, 2005 
Figure 4.3, Figure 4.5, Figure 4.7, Figure 4.9, and Figure 4.11 show the predicted contributions of Full Training scenario activities to 24-hour average surface $\mathrm{PM}_{10}$ concentrations for April 26, April 27, April 28, April 29, and April 30, respectively, when vehicular activities occur over a 10-hour period.

Figure 4.4, Figure 4.6, Figure 4.8, Figure 4.10, and Figure 4.12 show the corresponding predicted peak 1hour average contributions to surface $\mathrm{PM}_{10}$ concentrations for these same dates. Comparing these figures and the corresponding top 50 tables of Appendix $\mathrm{C}$ shows that the highest local concentration contributions to the 24-hour $\mathrm{PM}_{10}$ average resulted from military vehicle movements on April 30 when winds were light and variable. Under such light wind conditions, particulates generated by vehicular movement stay in the area of generation and are not readily dispersed. The top 50 tables for April 30 (see Appendix C) show that the maximum 24-hour average concentration contribution occurs within Dona Ana 1 subarea " $b$ ” and is equal to approximately $42 \mu \mathrm{g} / \mathrm{m}^{3}$.

For conducting Full Training Scenario simulations with the potential condition of all vehicular activity occurring in 1 hour, the release period was set from 0700 to 0800 MST. Based on the observed timing of the predicted peak 1-hour average concentration contributions in the 10-hour emission-duration simulations, this selection is consistent with the stated desire of Fort Bliss staff to try to time the release so as to maximize the potential for high hourly concentration contributions. The potential condition of vehicular activity compressed into 1 hour reflects a situation where combat training involving vehicular movement is focused into a limited time frame, while the remainder of the training day is dedicated to non-vehicular-movement-training (e.g., base-camp activities, equipment checks, training setup). The release period for this scenario was set at a consistent time to facilitate day-to-day comparisons. The predicted contributions of this compressed release to 24-hour average $\mathrm{PM}_{10}$ concentrations are shown in Figure 4.13, Figure 4.15, Figure 4.17, Figure 4.19, Figure 4.21, and Figure 4.23 for April 25, 26, 27, 28, 29, and 30, respectively, while Figure 4.14, Figure 4.16, Figure 4.18, Figure 4.20, Figure 4.22, and Figure 4.24 show the corresponding predicted peak 1-hour average concentration contributions to surface $\mathrm{PM}_{10}$ concentrations for the same dates. The peak 1-hour average concentration contributions for the compressed release occur consistently at 0700 to 0800 MST on each simulated day because under this extreme condition, all dust sources cease at $0800 \mathrm{MST}$.

Compressing all vehicular activity, and thus all emission sources, into 1 hour as opposed to distributing the activity over 10 hours leads to higher peak 1-hour average concentration contributions. For example, compare the side-by-side plots of the April 25 peak 1-hour $\mathrm{PM}_{10}$ concentration contributions in Figure 4.25; on the left is the plot from the 1-hour activity simulation while on the right is the plot from the 10-hour activity simulation. The highest contour in the left plot (1-hour activity duration) is for a concentration contribution of $500 \mu \mathrm{g} / \mathrm{m}^{3}$ while in right plot (10-hour activity duration), it is $50 \mu \mathrm{g} / \mathrm{m}^{3}$.

Compressing all vehicular activity into 1 hour also impacts the 24-hour average concentration contributions. For example, compare the side-by-side plots of the 24-hour average contributions on April 25 in Figure 4.26. The left plot again is from the 1-hour activity simulation while the right plot is from the 10-hour activity simulation. Not only does a higher concentration contribution contour of $50 \mu \mathrm{g} / \mathrm{m}^{3}$ appear in the left plot (1-hour activity duration), but larger geographic areas are encompassed by the 1and $10-\mu \mathrm{g} / \mathrm{m}^{3}$ contours relative to the right plot (10-hour activity duration). The extreme example of this can be seen in Figure 4/27, where the 24-hour average results on April 30 for 1-hour vehicular activity (left) and 10-hour vehicular activity (right) simulations are shown. In the left plot (1-hour activity duration), not only does the higher concentration contribution contour of $50 \mu \mathrm{g} / \mathrm{m}^{3}$ appear throughout most of the Dona Ana 1 Training Area, but areas experiencing $10-\mu \mathrm{g} / \mathrm{m}^{3}$ concentration contributions have 
merged and cover a wider geographic area relative to that in the right plot. As noted previously, winds on April 30 were light and variable (see Appendix B), allowing the high concentration plume generated by the compressed, 1-hour vehicular activities to hang over the source regions and disperse only gradually. This phenomenon subsequently leads to higher individual hour concentration contributions and thus a higher overall 24-hour average concentration contribution.

While performing the simulations and examining results for each hour, we noted that the contribution of scenario training activities to hourly $\mathrm{PM}_{10}$ concentrations generally was noticeable 4 to 8 hours after the cessation of vehicular activity. Days with higher wind speeds had faster plume dispersal.

Peak 1-hour and 24-hour average concentration contributions were generally highest in the vicinity of the "Combat Training Dona Ana 1" area (see Figure 3.1). In the Full Training scenario, this maneuver box contains a full HBCT, like the "Combat Training McGregor” area. However, it occupies approximately one third the geographic region of the "Combat Training McGregor" area. Vehicular density is highest in the "Combat Training Dona Ana 1" area, resulting in more concentrated dust sources within the model simulations. 




Figure 4.3. Predicted 24-Hour Average $\mathbf{P M}_{10}$ Concentration Contributions: DUSTRAN Simulation of the Full Training Scenario (10-Hour Vehicular Activity Duration) for April 26, 2005 




Figure 4.4. Predicted Peak 1-Hour $\mathrm{PM}_{10}$ Concentration Contributions: DUSTRAN Simulation of the Full Training Scenario (10-Hour Vehicular Activity Duration), 0800-0900 MST, April 26, 2005 


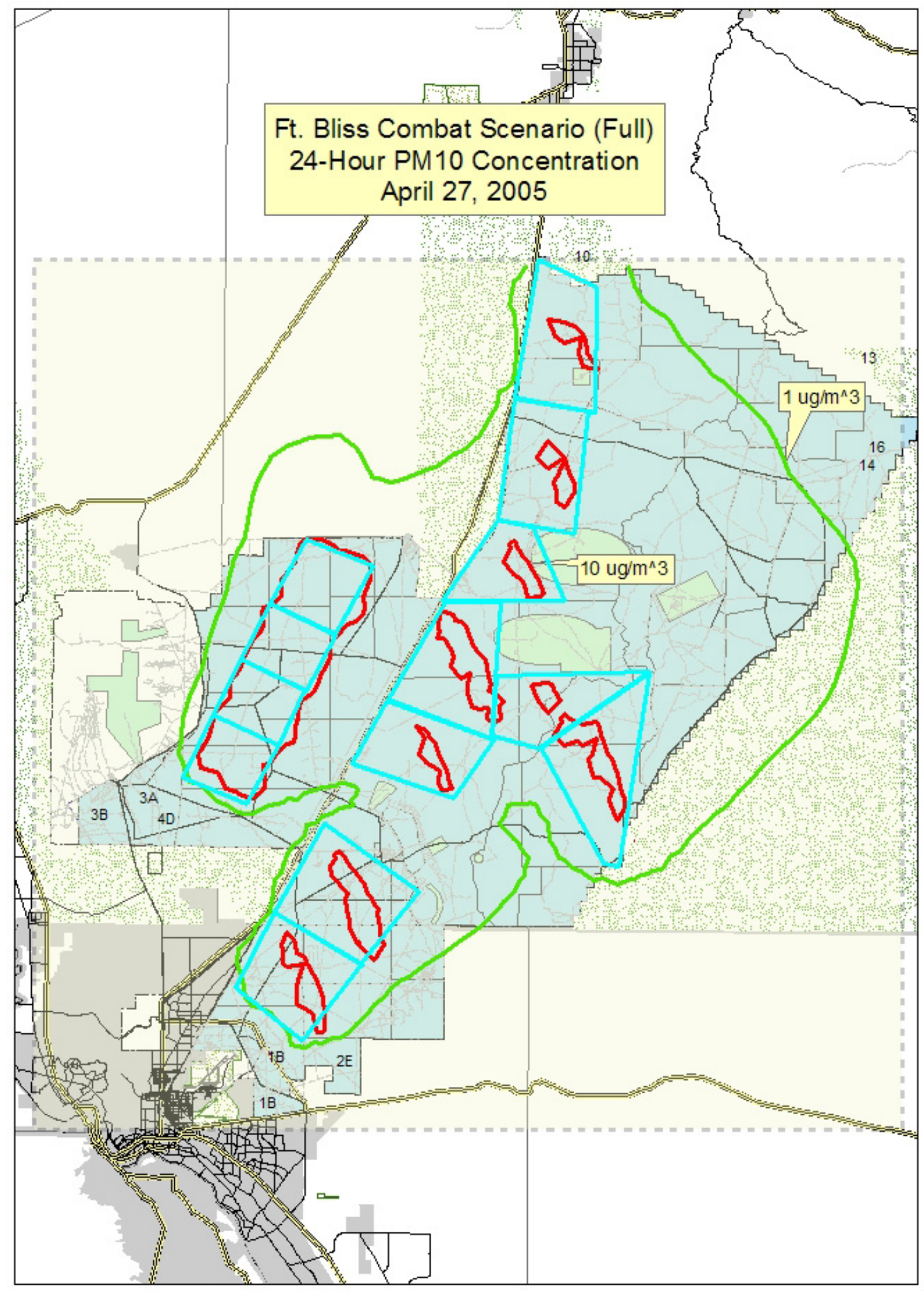

Figure 4.5. Predicted 24-Hour Average $\mathbf{P M}_{10}$ Concentration Contributions: DUSTRAN Simulation of the Full Training Scenario (10-Hour Vehicular Activity Duration) for April 27, 2005 


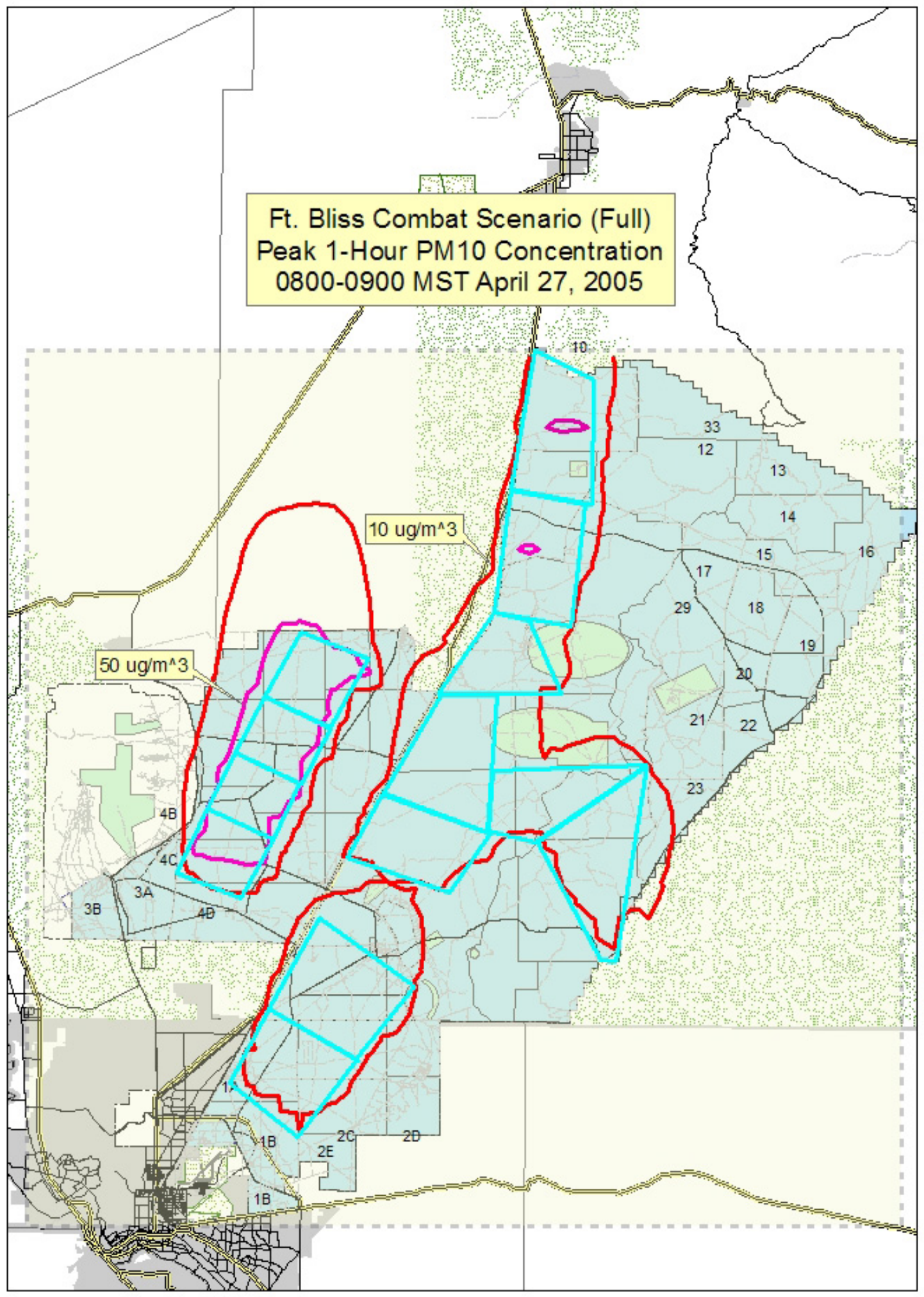

Figure 4.6. Predicted Peak 1-Hour $\mathrm{PM}_{10}$ Concentration Contributions: DUSTRAN Simulation of the Full Training Scenario (10-Hour Vehicular Activity Duration), 0800-0900 MST, April 27, 2005 


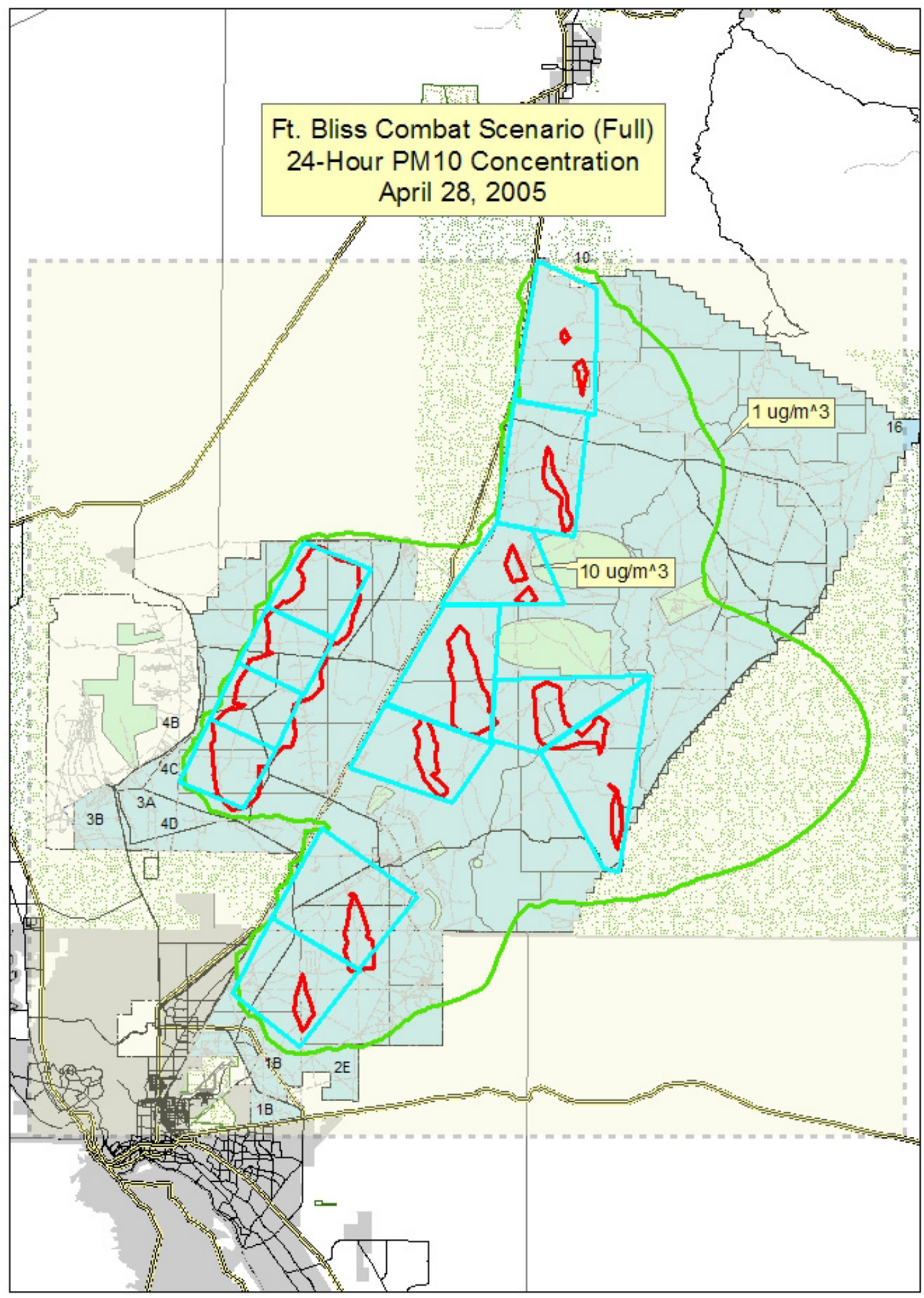

Figure 4.7. Predicted 24-Hour Average $\mathrm{PM}_{10}$ Concentration Contributions: DUSTRAN Simulation of the Full Training Scenario (10-Hour Vehicular Activity Duration) for April 28, 2005 


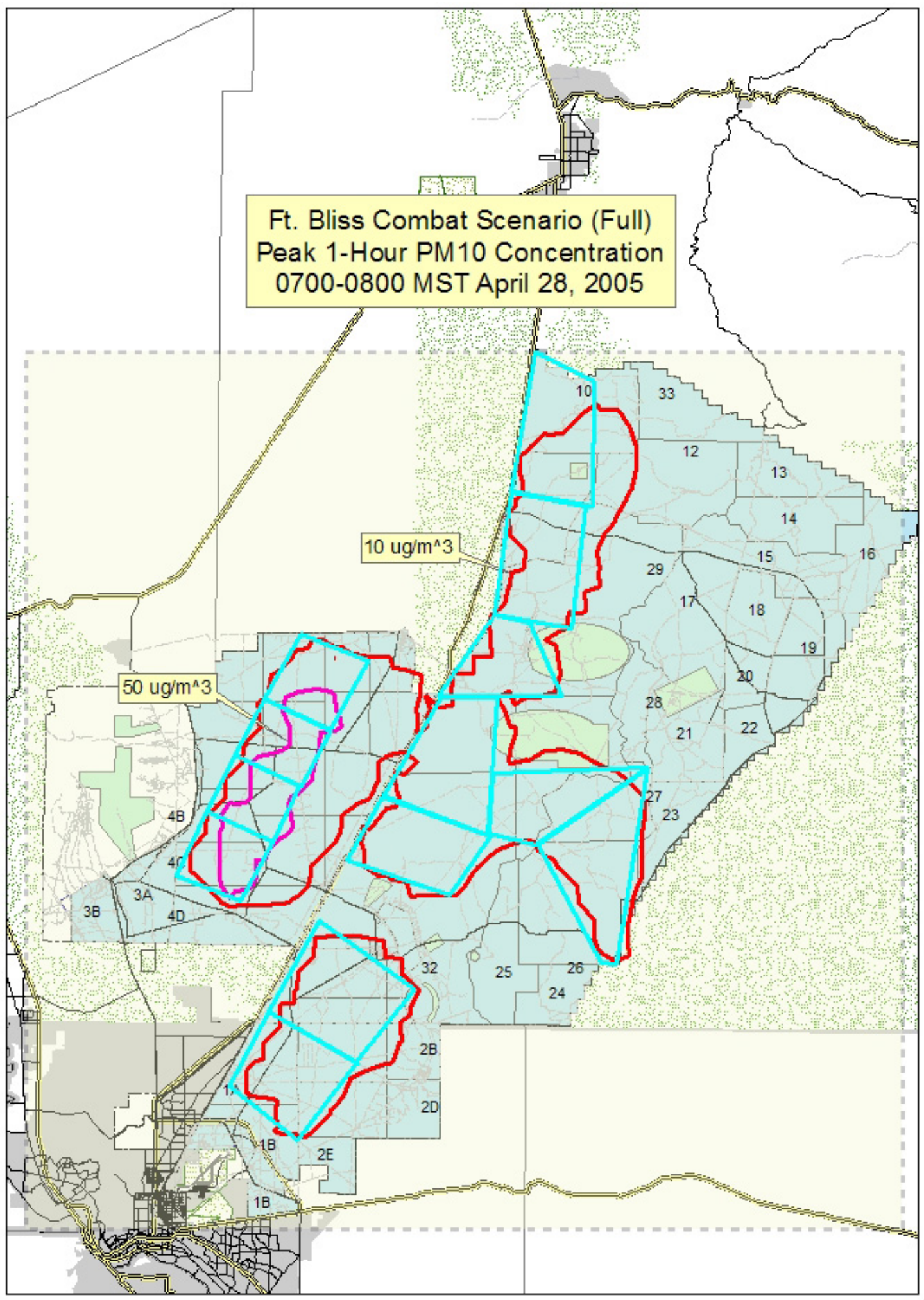

Figure 4.8. Predicted Peak 1-Hour $\mathrm{PM}_{10}$ Concentration Contributions: DUSTRAN Simulation of the Full Training Scenario (10-Hour Vehicular Activity Duration), 0700-0800 MST, April 28, 2005 


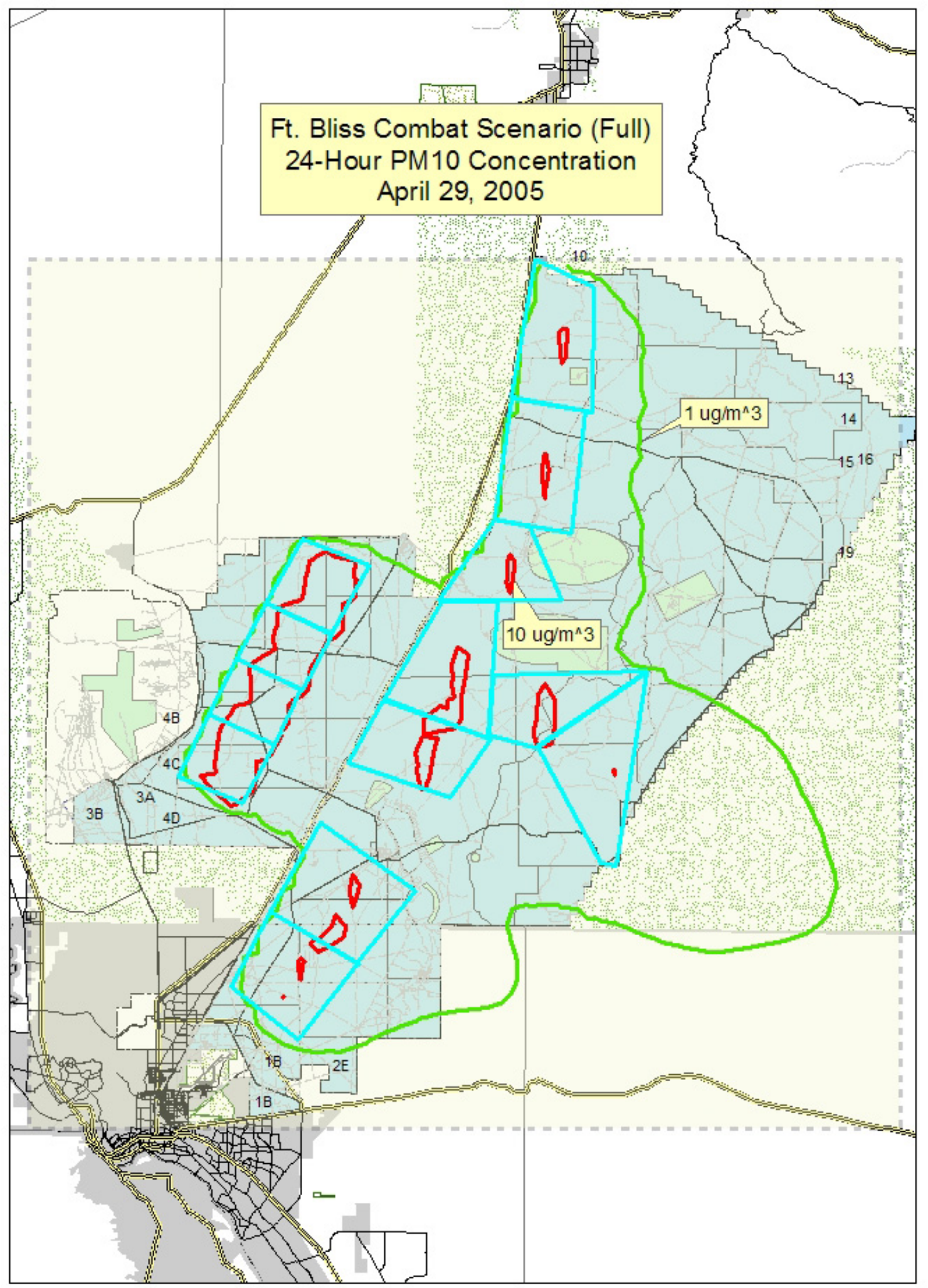

Figure 4.9. Predicted 24-Hour Average $\mathbf{P M}_{10}$ Concentration Contributions: DUSTRAN Simulation of the Full Training Scenario (10-Hour Vehicular Activity Duration) for April 29, 2005 


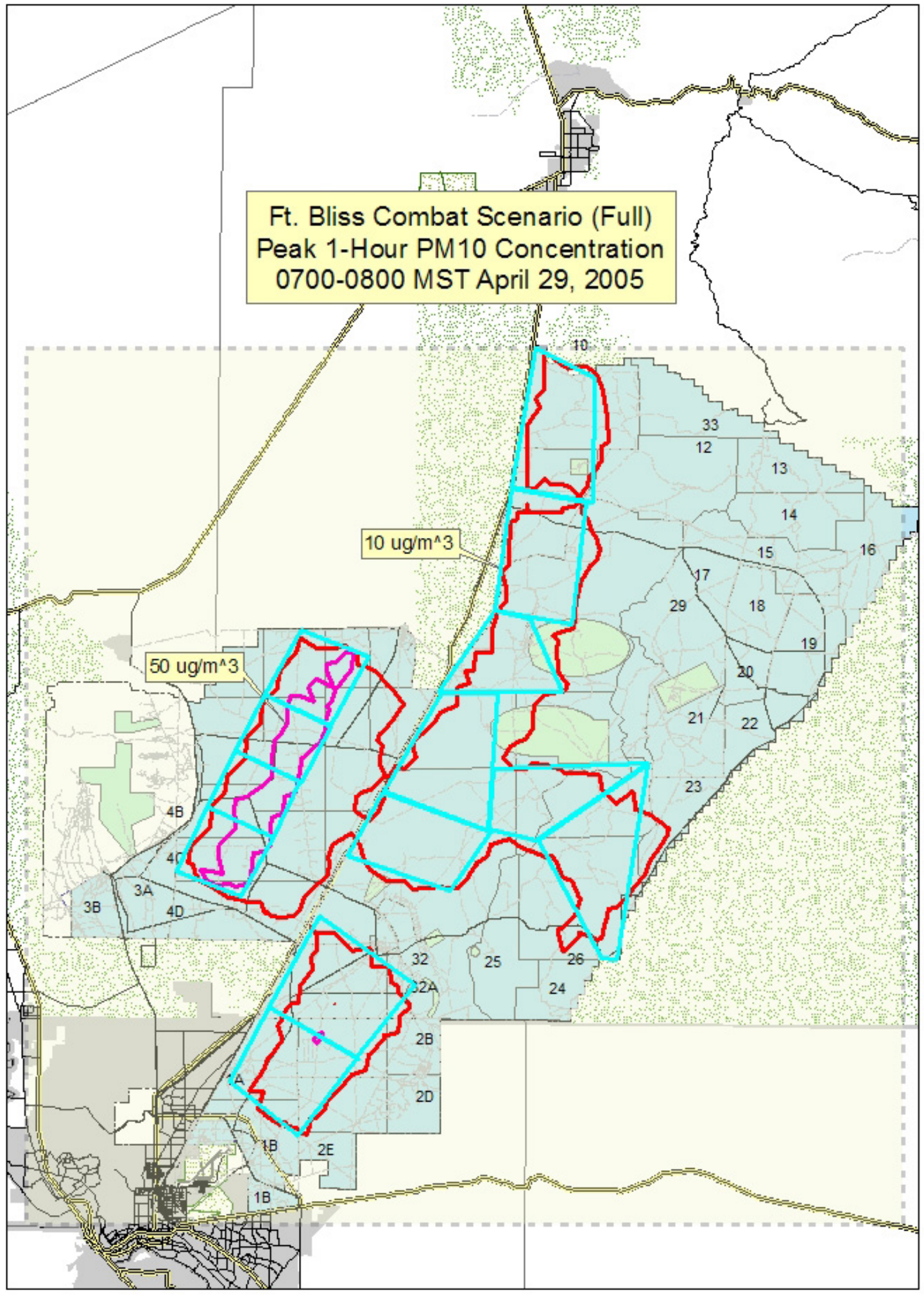

Figure 4.10. Predicted Peak 1-Hour $\mathbf{P M}_{10}$ Concentration Contributions: DUSTRAN Simulation of the Full Training Scenario (10 Hour Vehicular Activity Duration), 0700-0800 MST, April 29, 2005 


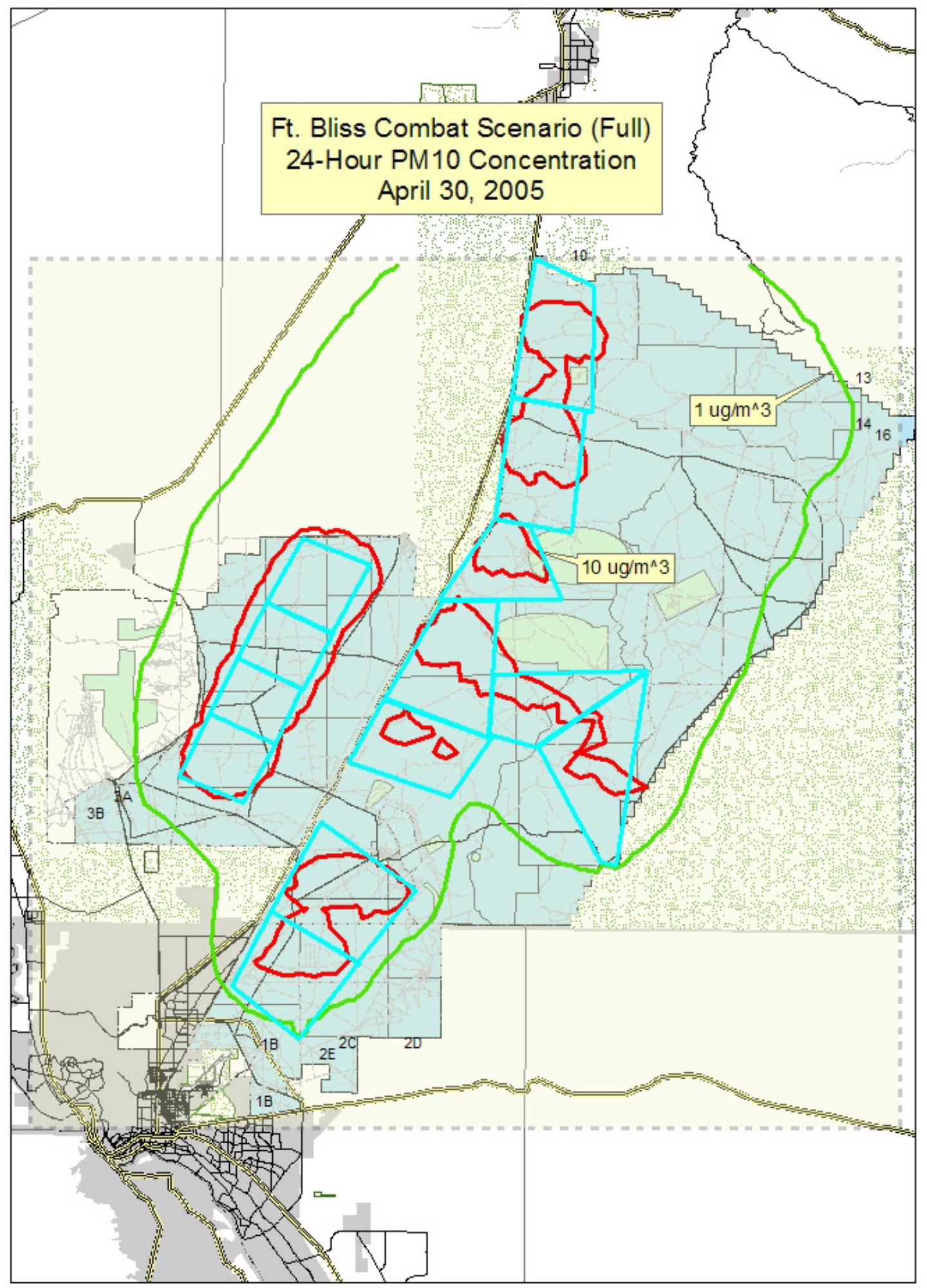

Figure 4.11. Predicted 24-Hour Average $\mathbf{P M}_{10}$ Concentration Contributions: DUSTRAN Simulation of the Full Training Scenario (10-Hour Vehicular Activity Duration) for April 30, 2005 


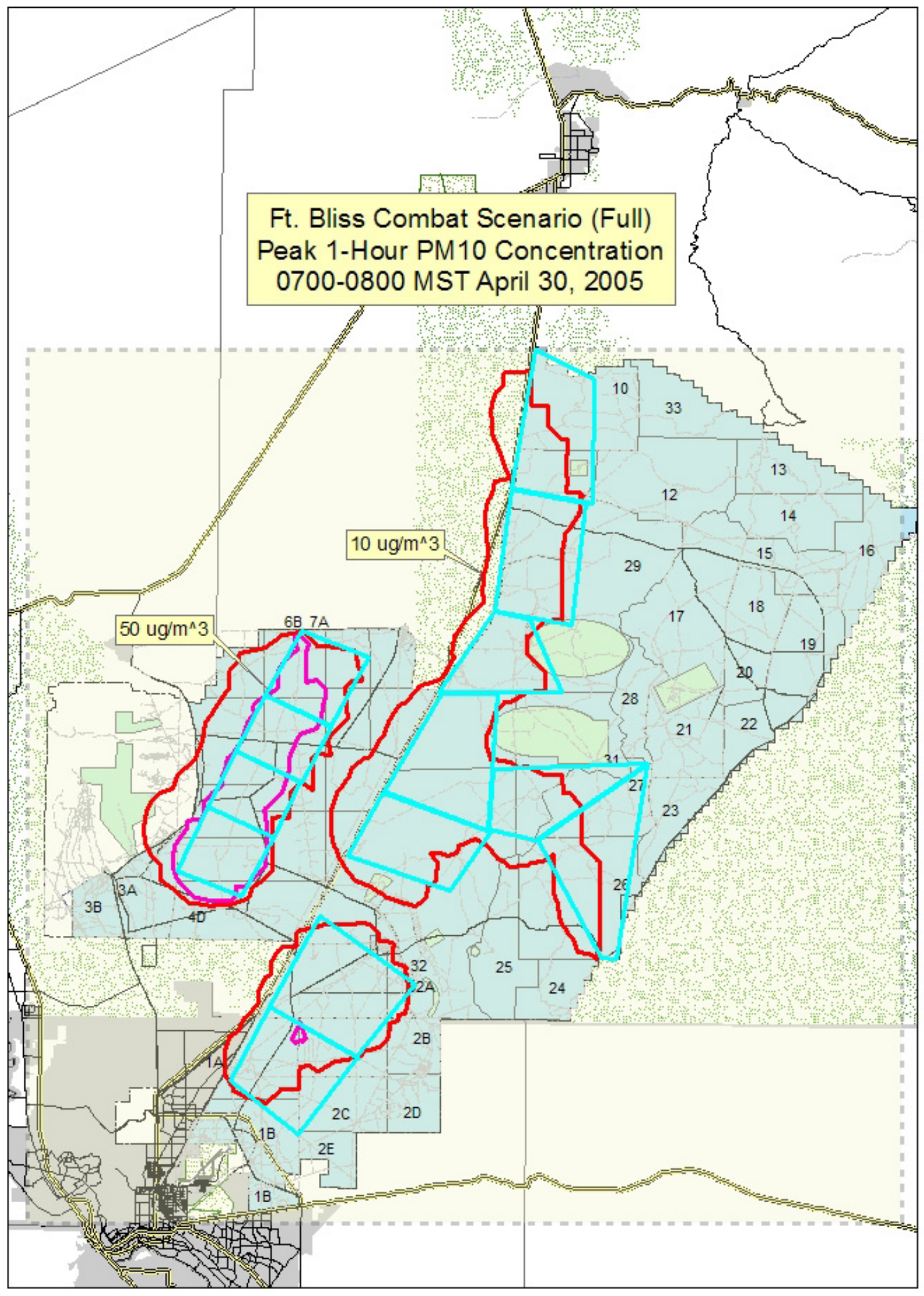

Figure 4.12. Predicted Peak 1-Hour $\mathbf{P M}_{10}$ Concentration Contributions: DUSTRAN Simulation of the Full Training Scenario (10-Hour Vehicular Activity Duration), 0700-0800 MST, April 30, 2005 




Figure 4.13. Predicted 24-Hour Average $\mathbf{P M}_{10}$ Concentration Contributions: DUSTRAN Simulation of the Full Training Scenario (1-Hour Vehicular Activity Duration) for April 25, 2005 


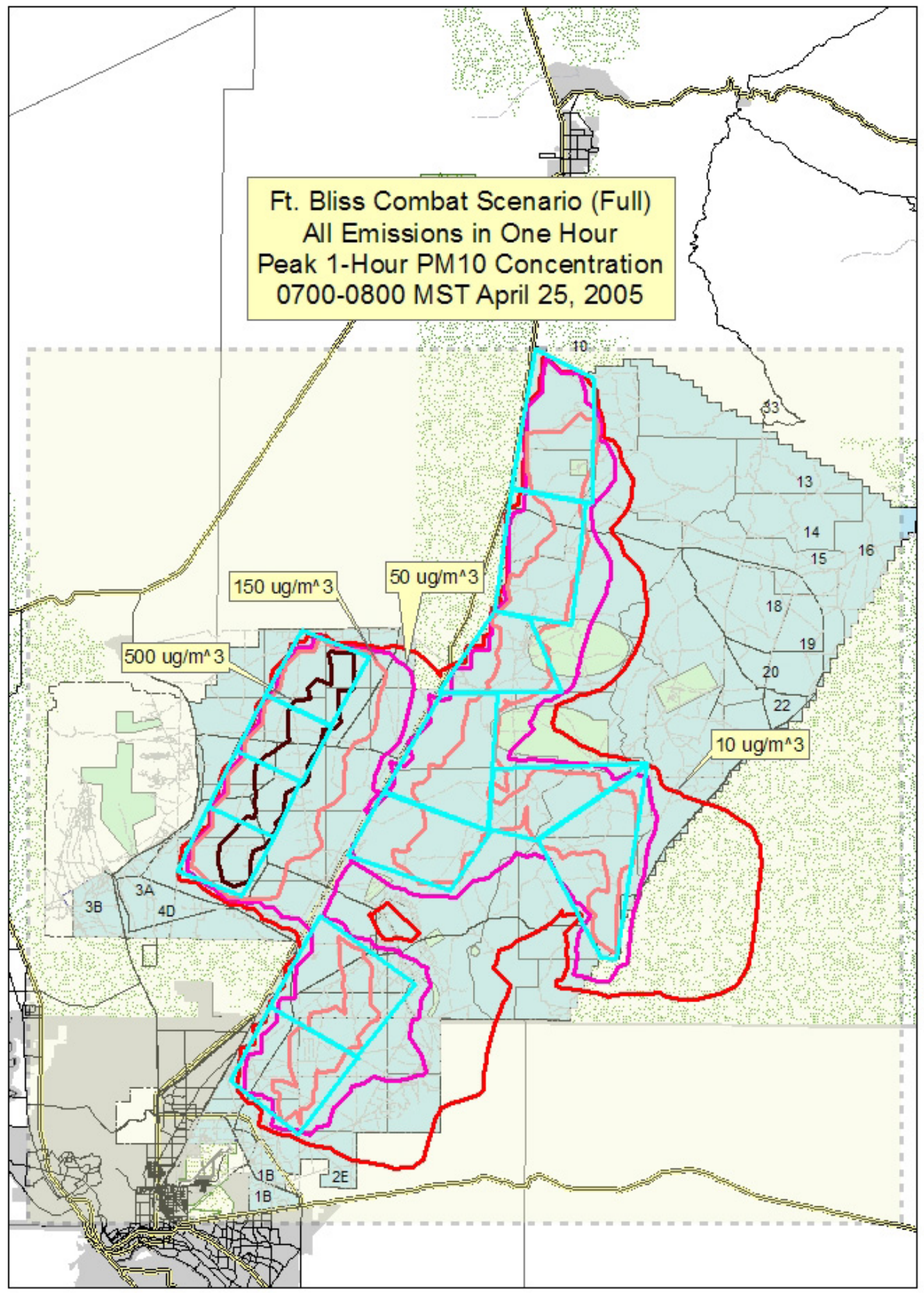

Figure 4.14. Predicted Peak 1-Hour $\mathrm{PM}_{10}$ Concentration Contributions: DUSTRAN Simulation of the Full Training Scenario (1-Hour Vehicular Activity Duration), 0700-0800 MST, April 25, 2005 


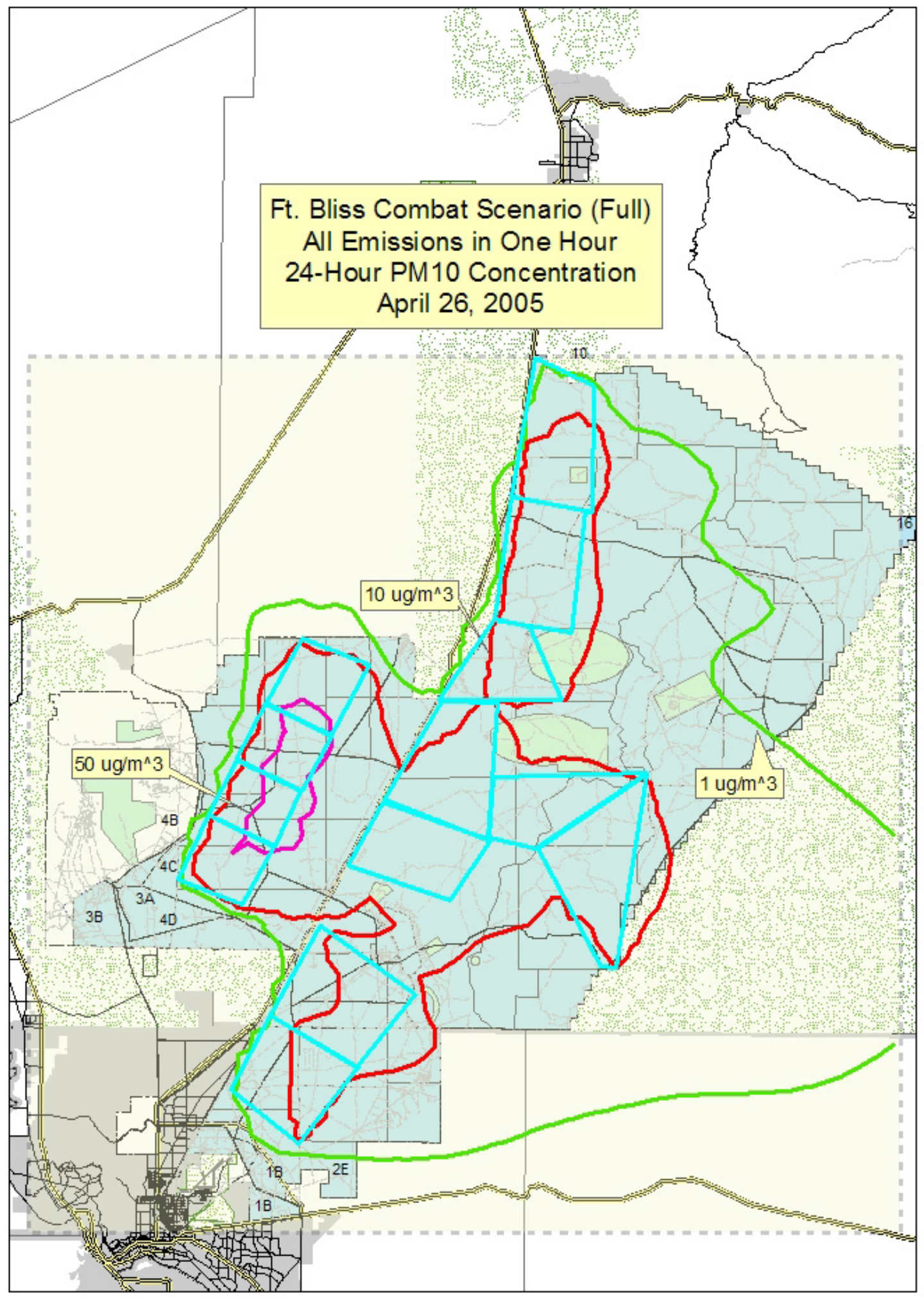

Figure 4.15. Predicted 24-Hour Average $\mathbf{P M}_{10}$ Concentration Contributions: DUSTRAN Simulation of the Full Training Scenario (1-Hour Vehicular Activity Duration) for April 26, 2005 


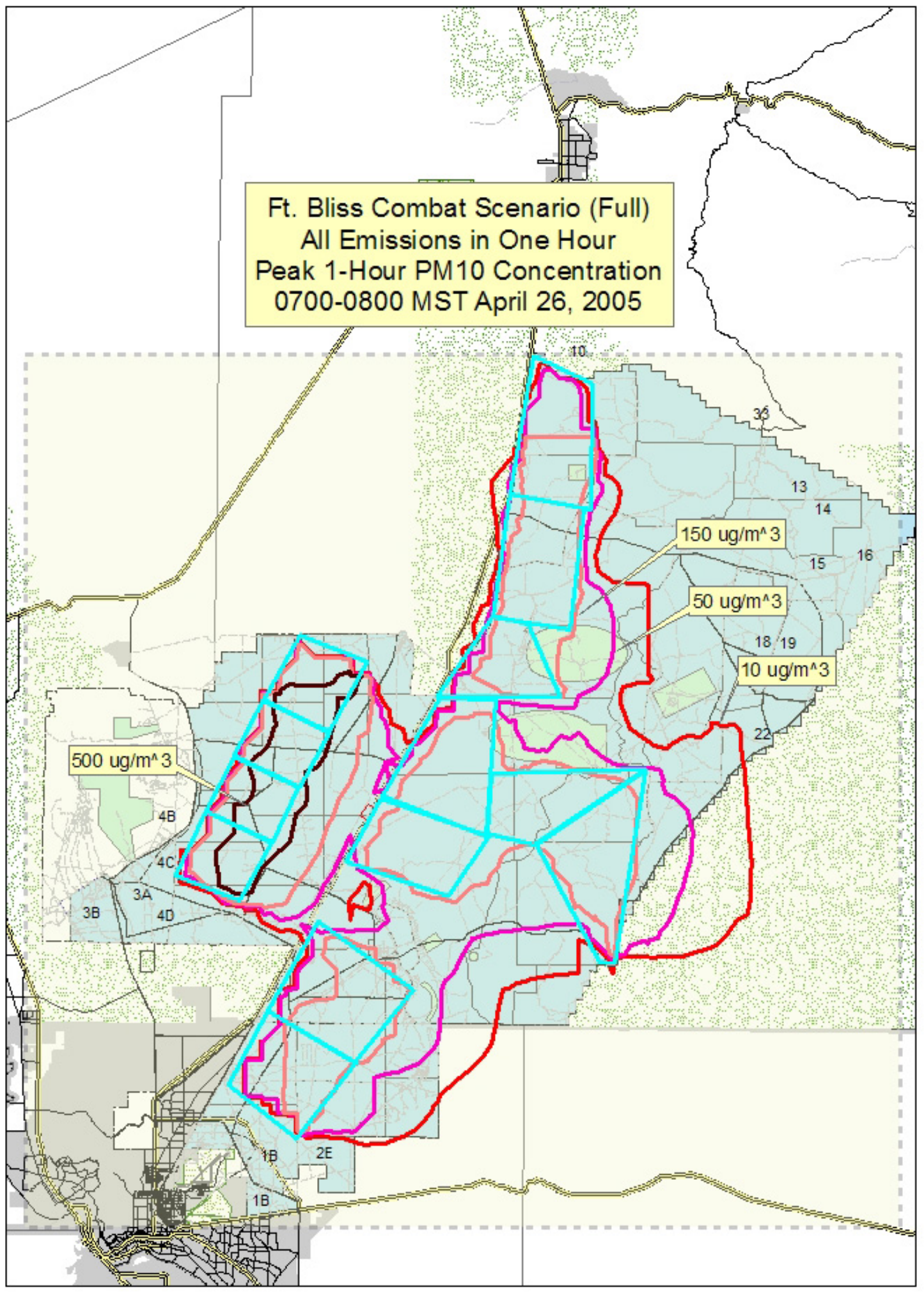

Figure 4.16. Predicted Peak 1-Hour $\mathbf{P M}_{10}$ Concentration Contributions: DUSTRAN Simulation of the Full Training Scenario (1-Hour Vehicular Activity Duration), 0700-0800 MST, April 26, 2005 




Figure 4.17. Predicted 24-Hour Average $\mathbf{P M}_{10}$ Concentration Contributions: DUSTRAN Simulation of the Full Training Scenario (1-Hour Vehicular Activity Duration) for April 27, 2005 


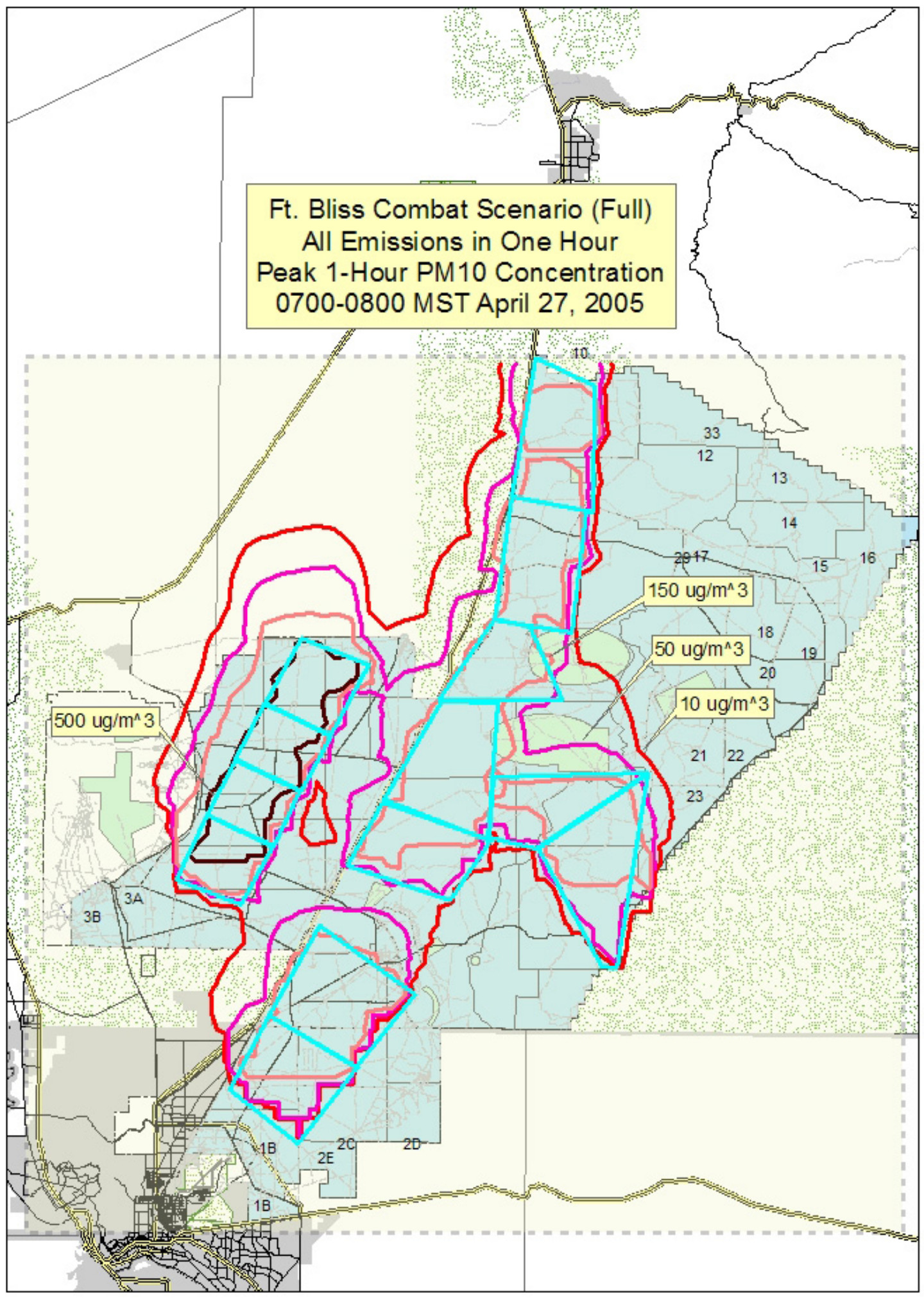

Figure 4.18. Predicted Peak 1-Hour $\mathbf{P M}_{10}$ Concentration Contributions: DUSTRAN Simulation of the Full Training Scenario (1-Hour Vehicular Activity Duration), 0700-0800 MST, April 27, 2005 


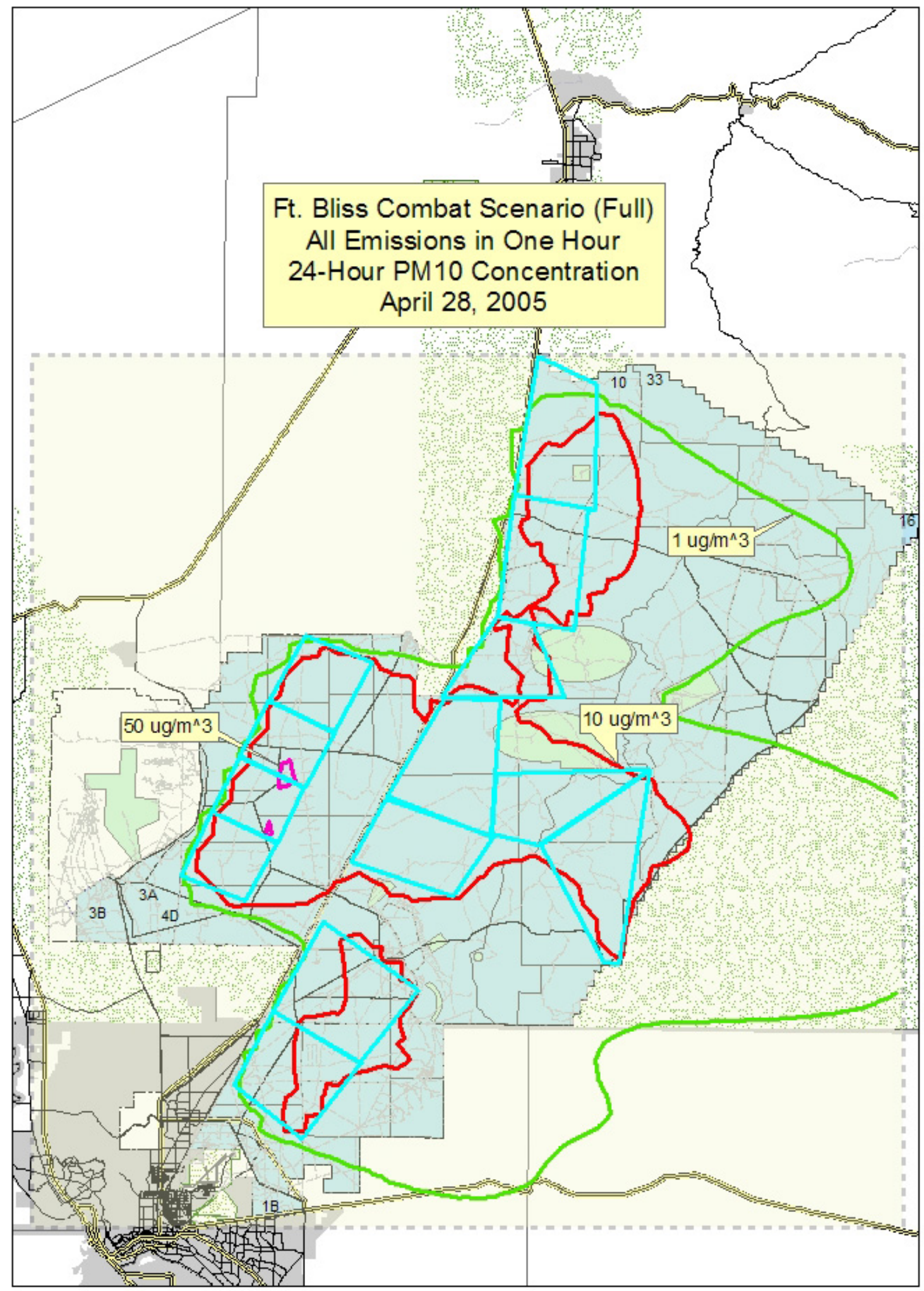

Figure 4.19. Predicted 24-Hour Average $\mathbf{P M}_{10}$ Concentration Contributions: DUSTRAN Simulation of the Full Training Scenario (1-Hour Vehicular Activity Duration) for April 28, 2005 


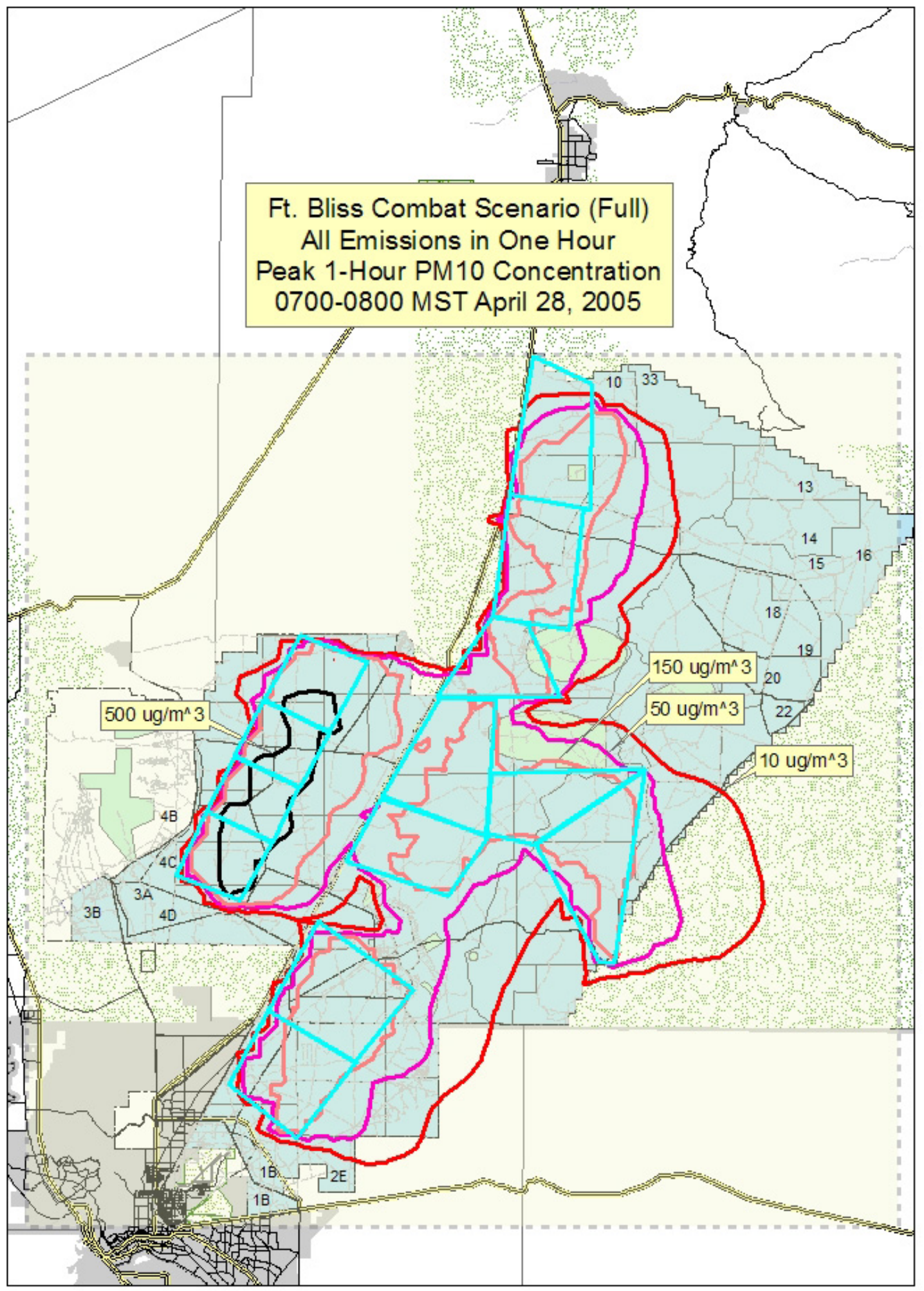

Figure 4.20. Predicted Peak 1-Hour $\mathrm{PM}_{10}$ Concentration Contributions: DUSTRAN Simulation of the Full Training Scenario (1-Hour Vehicular Activity Duration), 0700-0800 MST, April 28, 2005 


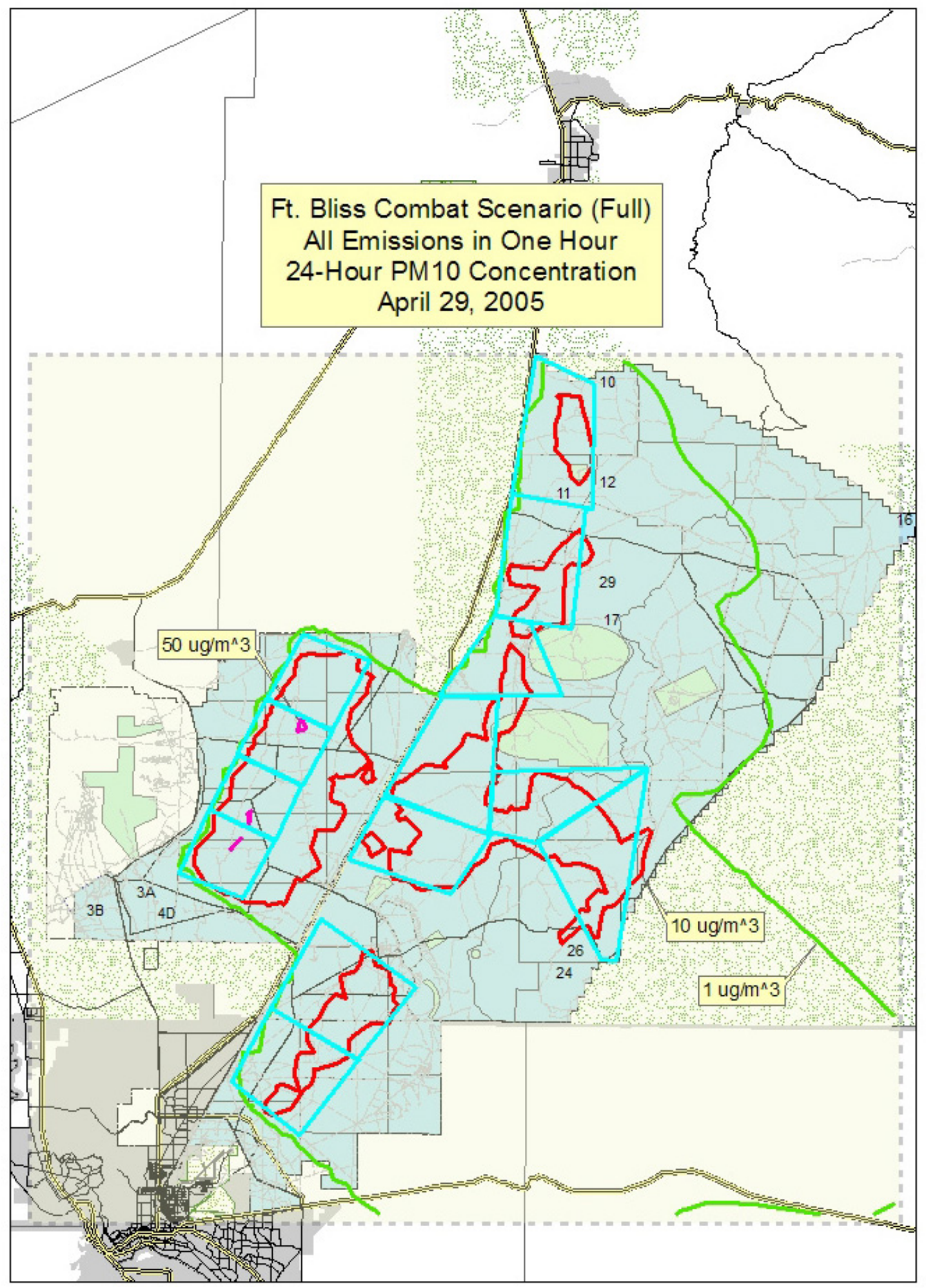

Figure 4.21. Predicted 24-Hour Average $\mathbf{P M}_{10}$ Concentration Contributions: DUSTRAN Simulation of the Full Training Scenario (1-Hour Vehicular Activity Duration) for April 29, 2005 


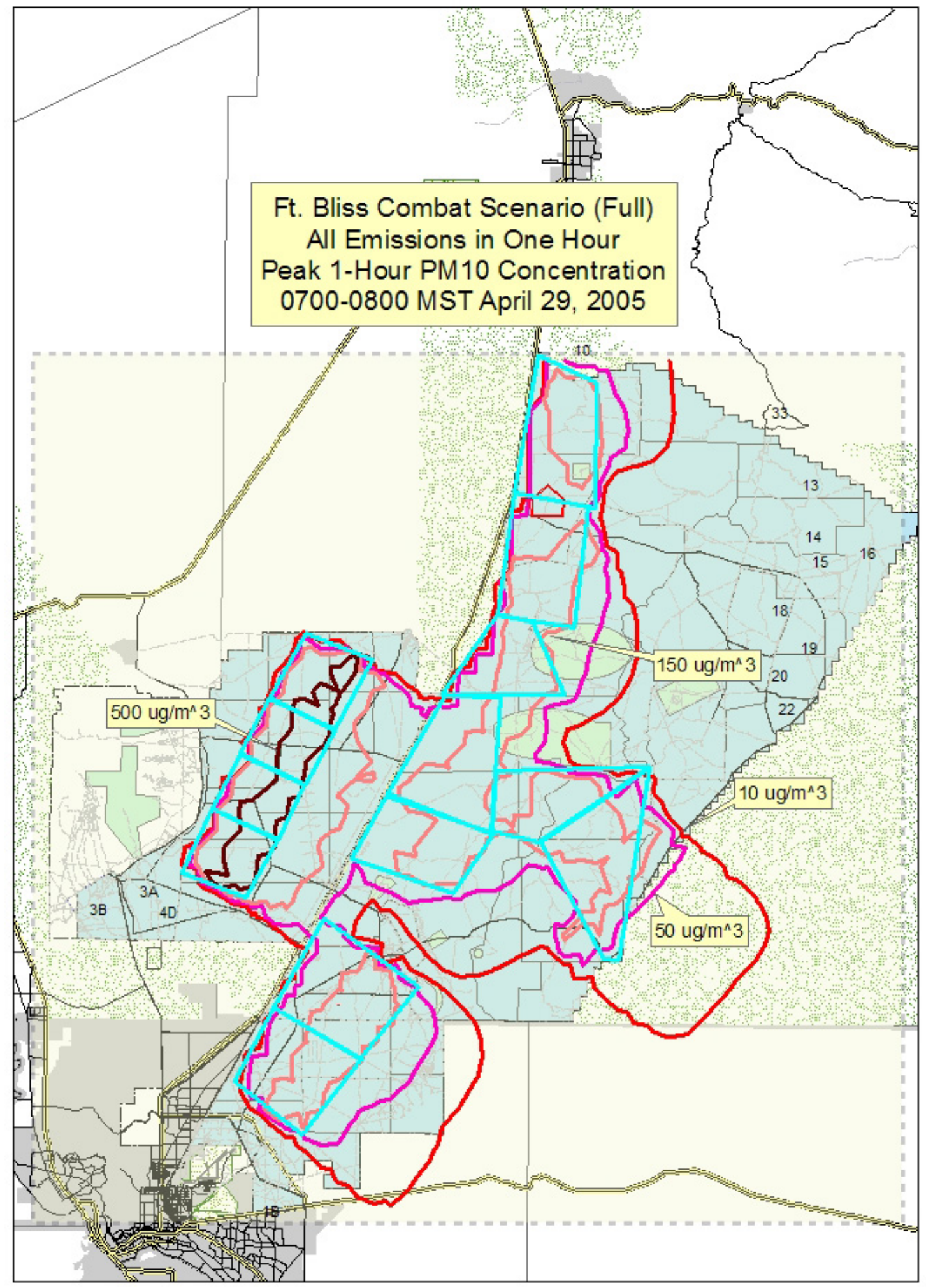

Figure 4.22. Predicted Peak 1-Hour $\mathbf{P M}_{10}$ Concentration Contributions: DUSTRAN Simulation of the Full Training Scenario (1-Hour Vehicular Activity Duration), 0700-0800 MST, April 29, 2005 


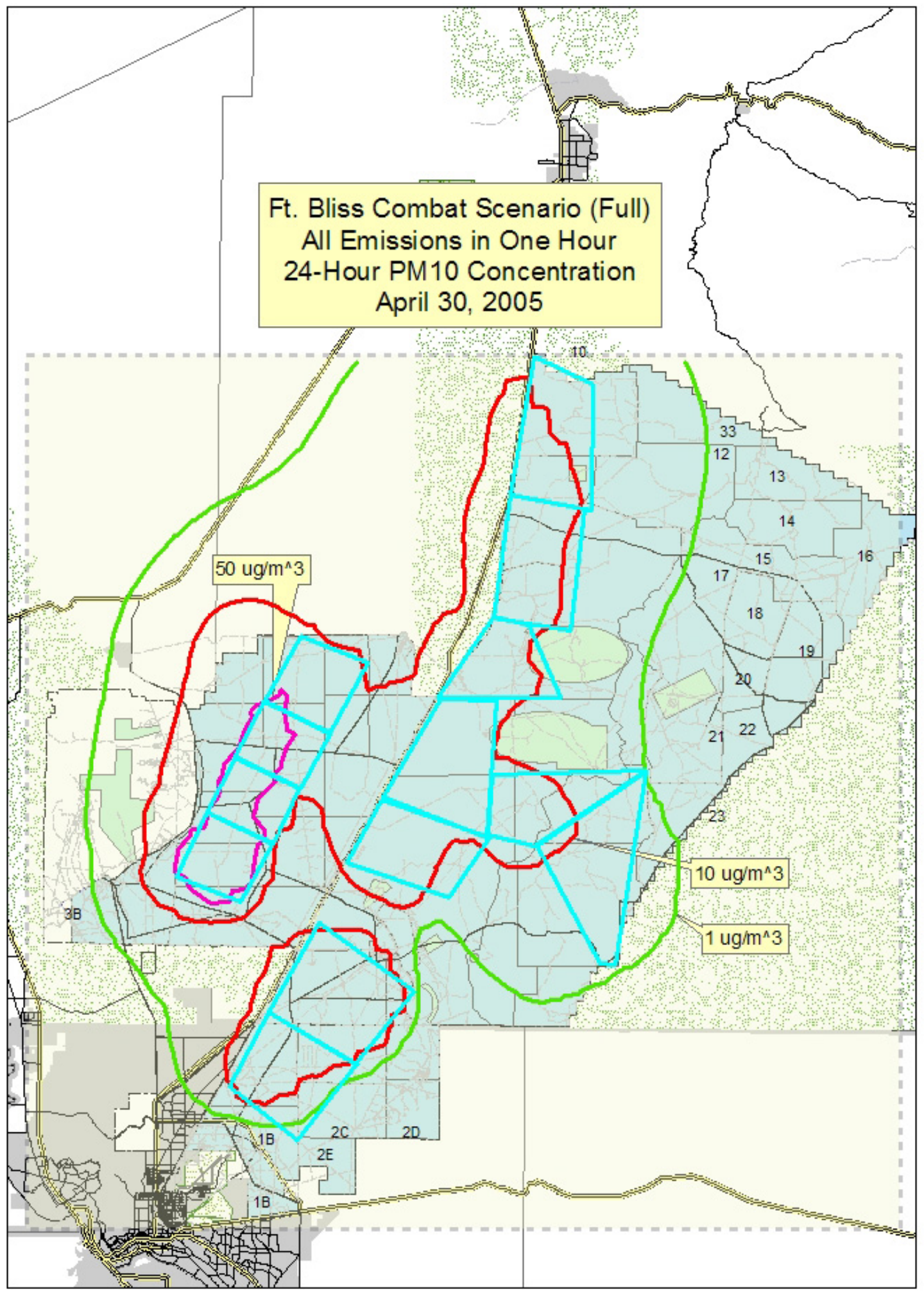

Figure 4.23. Predicted 24-Hour Average $\mathbf{P M}_{10}$ Concentration Contributions: DUSTRAN Simulation of the Full Training Scenario (1-Hour Vehicular Activity Duration) for April 30, 2005 


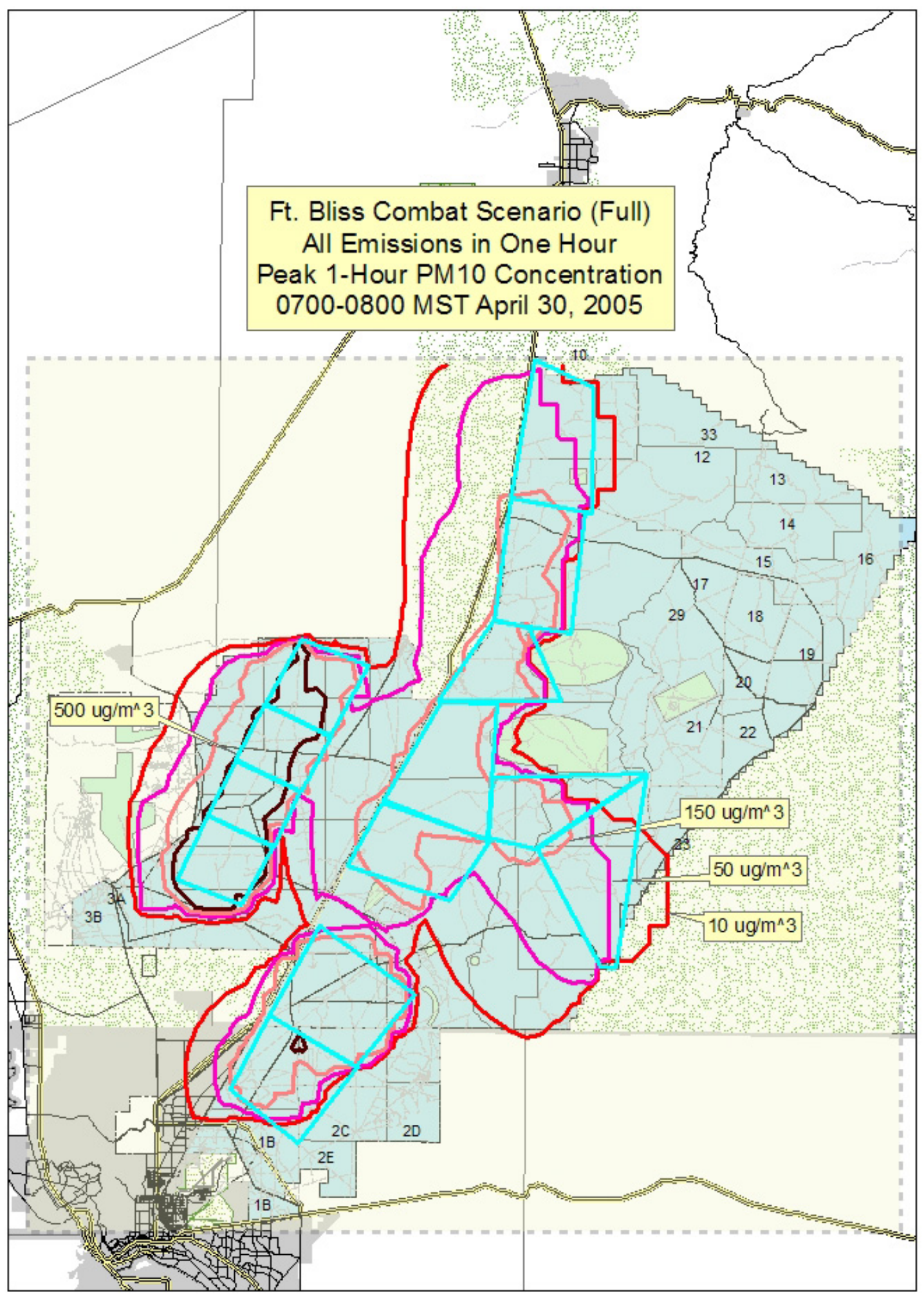

Figure 4.24. Predicted Peak 1-Hour $\mathbf{P M}_{10}$ Concentration Contributions: DUSTRAN Simulation of the Full Training Scenario (1-Hour Vehicular Activity Duration), 0700-0800 MST, April 30, 2005 


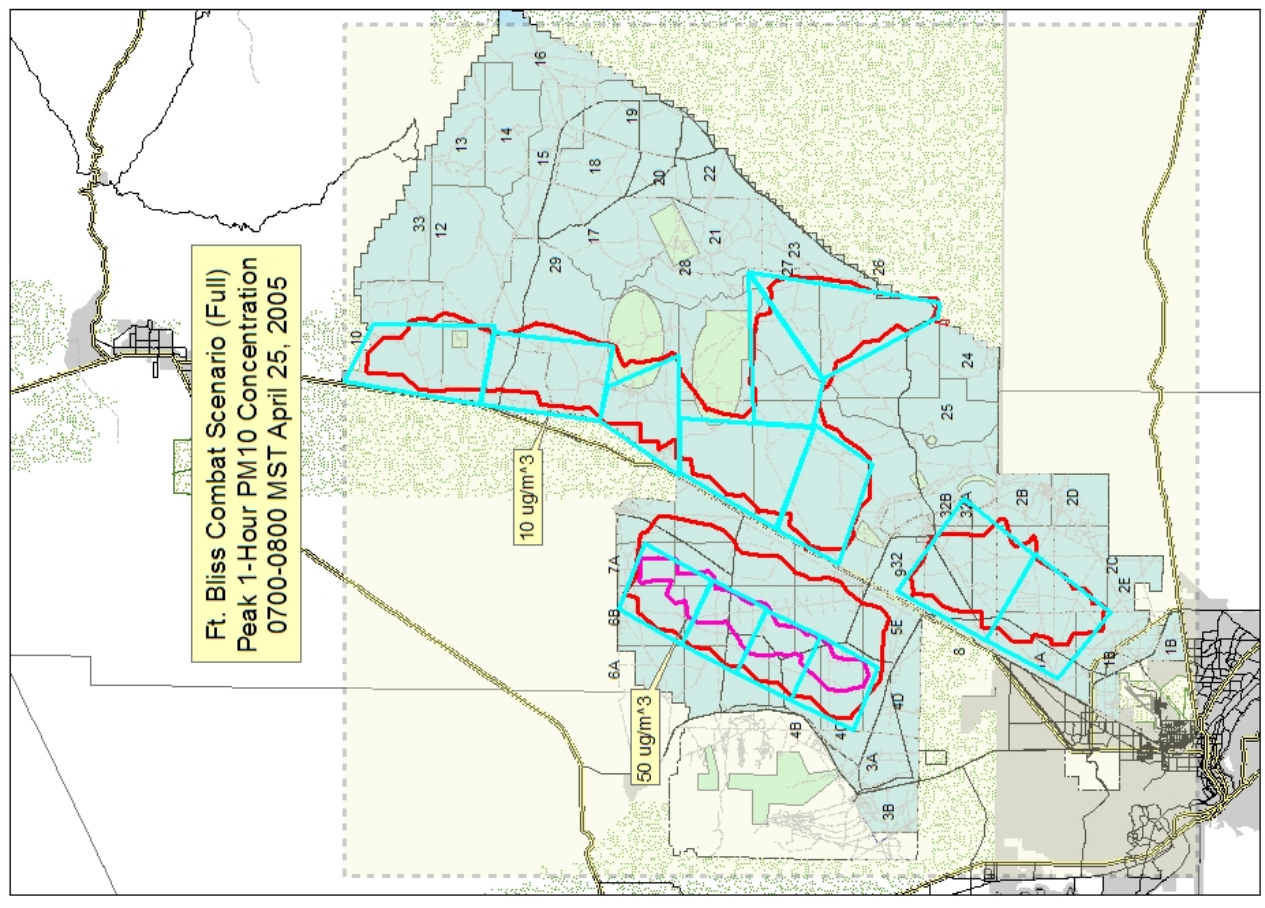

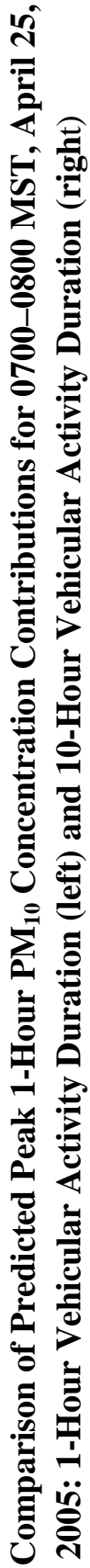

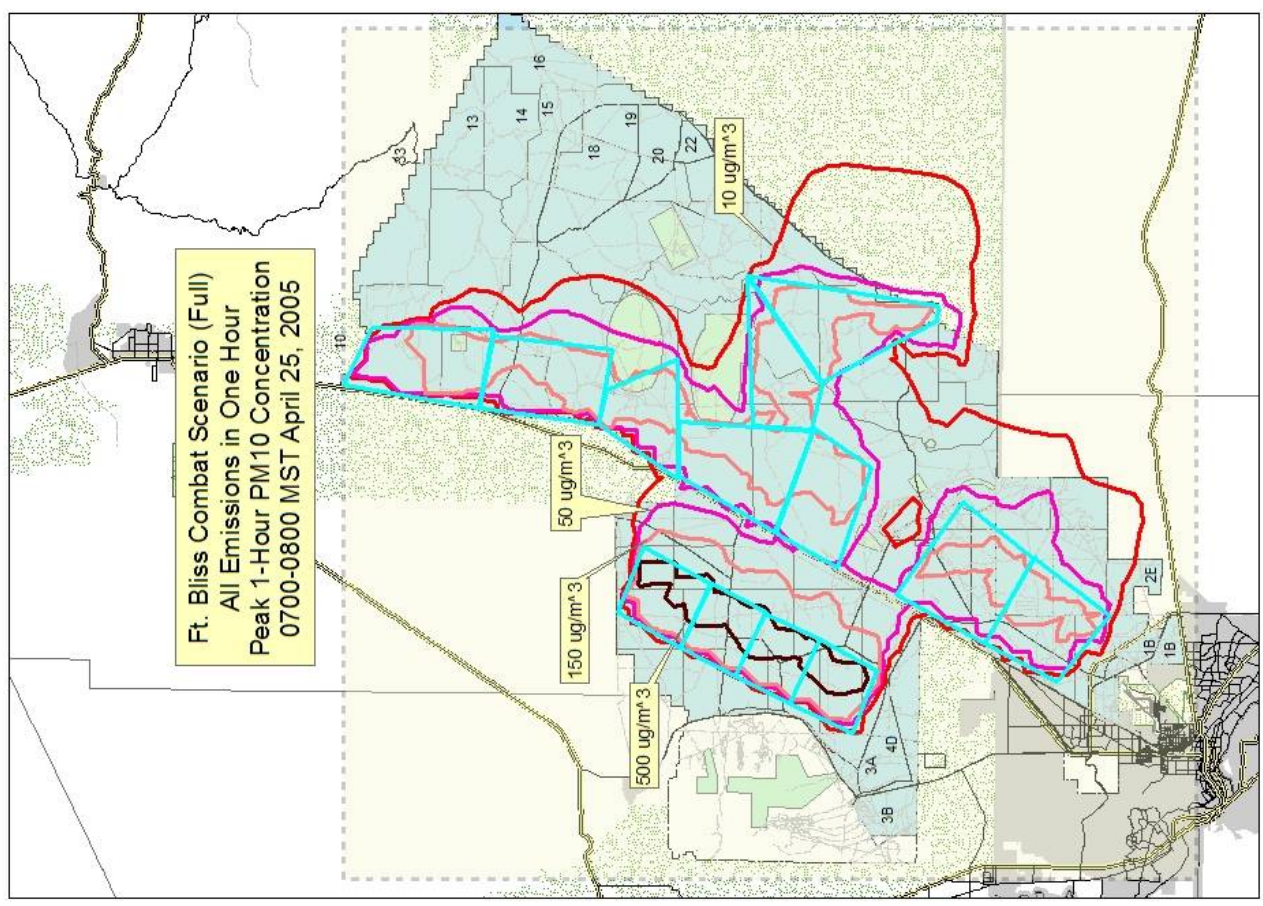

ثั 




.

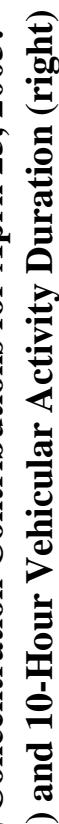

올

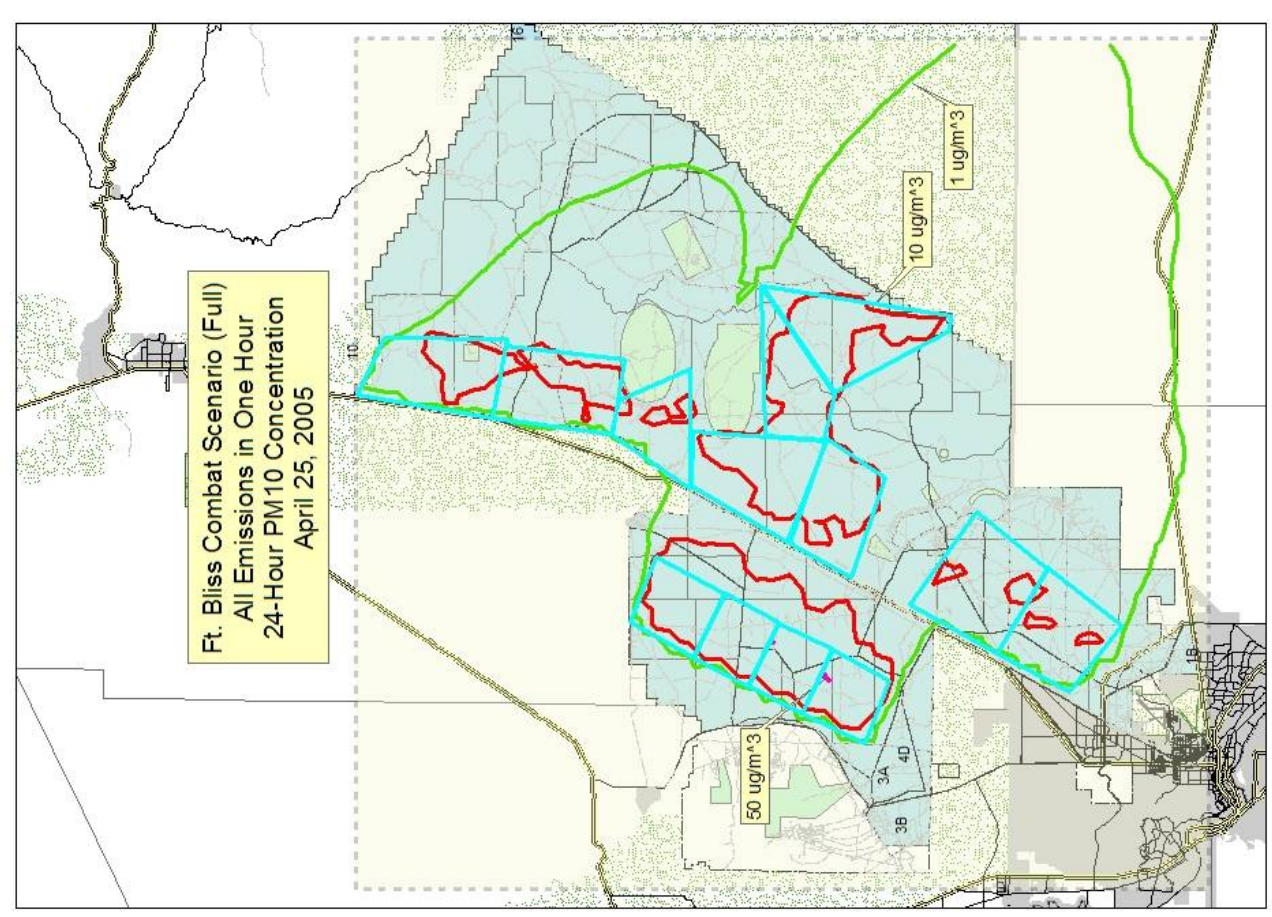

نे 


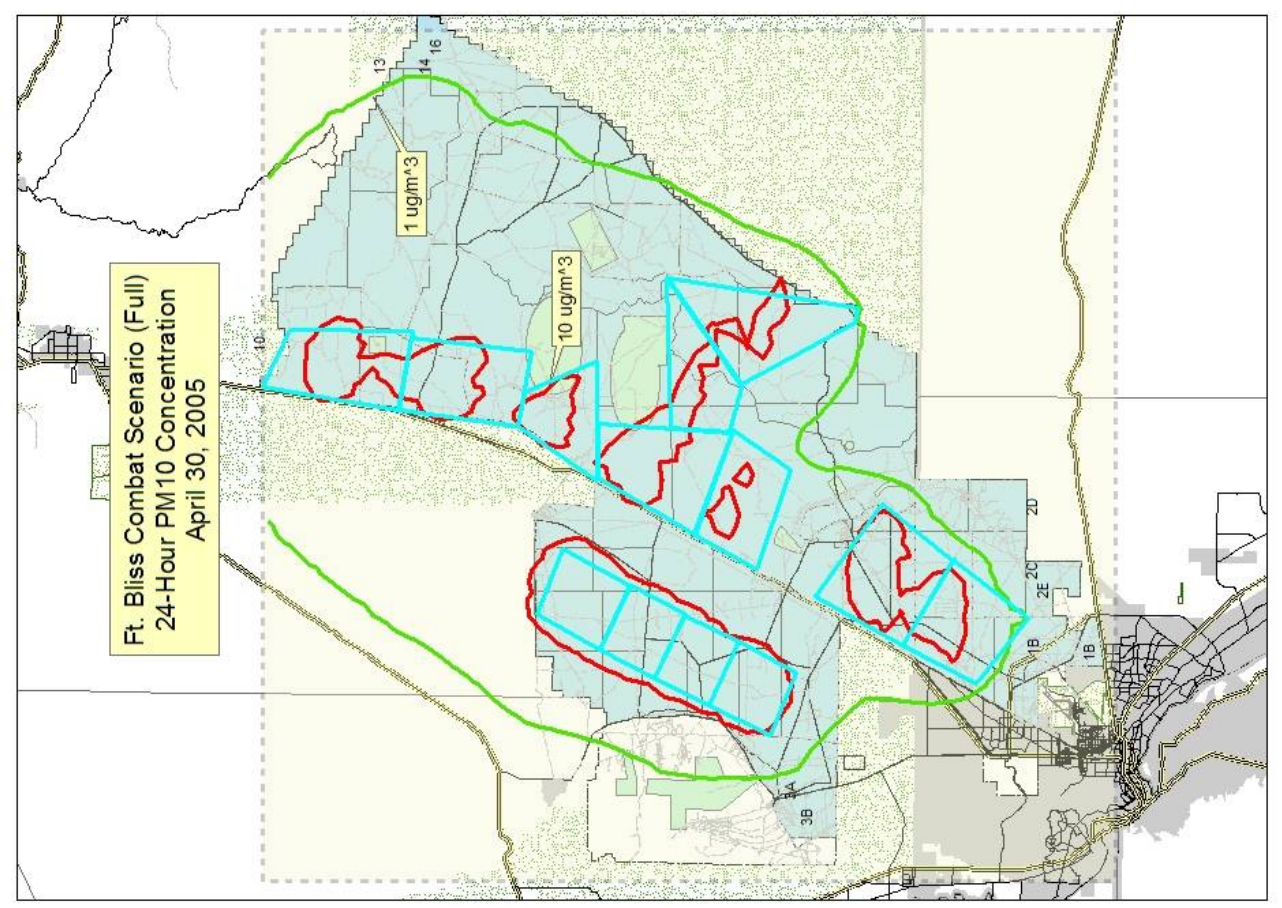

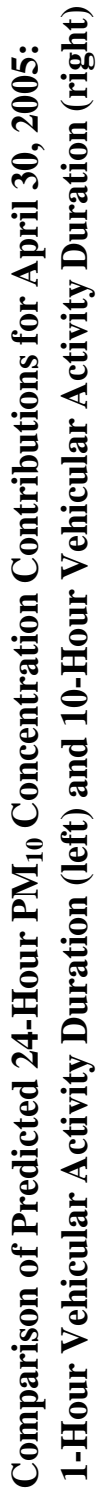

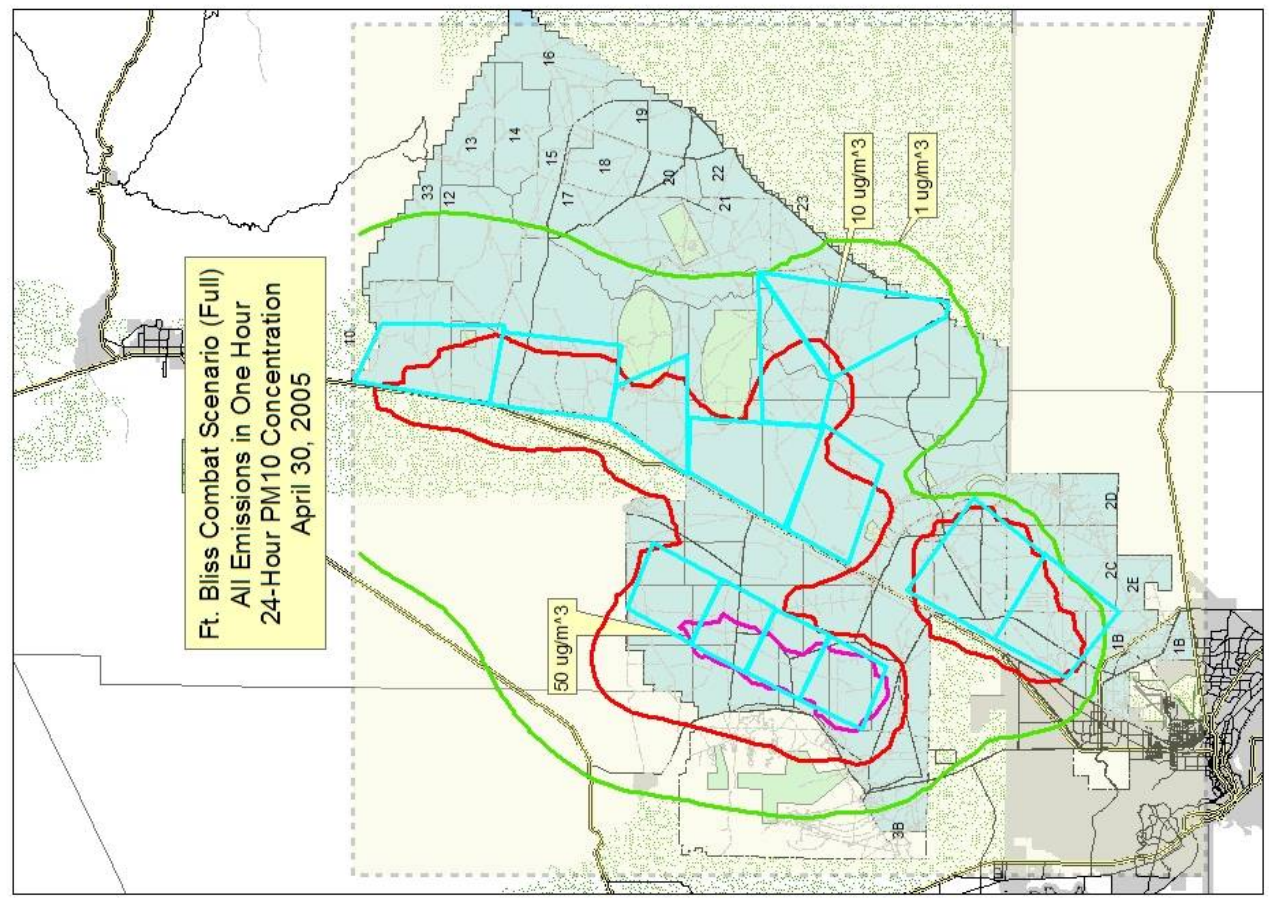

突 


\subsection{List of Persons Consulted}

Mr. Dallas Bash, Ft. Bliss

Mr. Walter Christensen, Ft. Bliss

Dr. Jack Gillies, Desert Research Institute

Dr. Hampden Kuhns, Desert Research Institute

Dr. Brian Locke, Ft. Bliss

Mr. Jesse Moncada, Ft. Bliss 


\subsection{References}

Allwine KJ, FC Rutz, WJ Shaw, BG Fritz, and BL Hoopes. 2004. Third Annual Progress Report: Development of a GIS-Based Complex Terrain Model for Atmospheric Dust Dispersion. PNNL-14555, Pacific Northwest National Laboratory, Richland, WA.

Allwine KJ, FC Rutz, WJ Shaw, JP Rishel, BG Fritz, EG Chapman, BL Hoopes and TE Seiple. 2006. DUSTRAN 1.0 User's Guide: A GIS-Based Atmospheric Dust Dispersion Modeling System. PNNL16055, Pacific Northwest National Laboratory, Richland, WA.

Booz Allen Hamilton. 2005. Prevention of Significant Deterioration (PSD) Analysis, Ft. Bliss, Texas, Ft. Bliss, New Mexico. Report available from Fort Bliss Directorate of Environment, Fort Bliss, TX.

Gillies JA., V Etyemezian, H Kuhns, D Nikolic, and DA Gillette. 2005a. “Effect of Vehicle Characteristics on Unpaved Road Dust Emissions.” Atmos. Environ. 39:2341-2347.

Gillies JA, WP Arnott, V Etyemezian, H Kuhns, H Moosmuller, D DuBois, M Abu-Allaban, G Schwemmer, DA Gillette, WG Nickling, R Varma, T Wilkerson, and R Varma. 2005b. Characterizing and Quantifying Local and Regional Particulate Matter Emissions from Department of Defense Installations. Final report prepared for the Strategic Environmental Research and Development Program under Project CP-1191, March 2005.

Scire JS, DG Strimaitis, and RJ Yamartino. 2000a. A User's Guide for the CALPUFF Dispersion Model (Version 5). Earth Tech, Inc., Concord, MA.

Scire JS, FR Robe, ME Fernau, and RJ Yamartino. 2000b. A User's Guide for the CALMET Meteorological Model (Version 5). Earth Tech, Inc., Concord, MA.

Scire JS, RJ Yamartino, GR Carmichael, and YS Chang. 1989. CALGRID: A Mesoscale Photochemical Grid Model Volume II - User's Guide. California Resources Board, Sacramento, CA.

U.S. Environmental Protection Agency (EPA). 2005. "Compilation of Air Pollutant Emission Factors (AP-42) Fifth Edition, Volume 1: Stationary Point and Area Sources.” U. S. Environmental Protection Agency, Research Triangle Park, NC. Available at: http://www.epa.gov/ttn/chief/ap42/ (accessed September 19, 2006). 


\section{Appendix A}

\section{Mapping of Heavy Brigade Combat Team Vehiclesto Dustran Vehicle Types}


Table A.1. Mapping of Vehicles in One Heavy Brigade Combat Team (HBCT) to Available DUSTRAN Vehicle Types. HBCT vehicle types are listed based on Booz Allen Hamilton (2005). The "Freightliner" designation represents loaded freightliners.

\begin{tabular}{|c|c|c|c|}
\hline Sources & $\begin{array}{c}\text { No. } \\
\text { Sources }\end{array}$ & $\begin{array}{l}\text { DUSTRAN Equivalent } \\
\text { (per source) }\end{array}$ & Comment \\
\hline \multicolumn{4}{|l|}{ Wheeled Vehicle } \\
\hline SET: CONTACT SUPPORT FIGHTING VEHICLE (TOW) & 2 & HMMWV & \\
\hline TRUCK UTILITY: S250 SHELTER CARRIER 4X4 W/E (HMMWV) & 2 & HMMWV & \\
\hline TRUCK UTILITY: HEAVY VARIANT HMMWV 4X4 10000 GVW W/E & 36 & HMMWV & \\
\hline TRACTOR WHEELED: DSL 4X4 W/EXCAVATOR AND FRONT LOADER & 4 & GMC G20 VAN & med. Wt $2.5-5$ tons \\
\hline TRUCK AMBULANCE: 4 LITTER ARMD 4X4 W/E (HMMWV) & 11 & HMMWV & \\
\hline TRUCK CARGO: TACTICAL 8X8 HEAVY EXPANDED MOBILITY W/W W/LT CRANE & 4 & GMC C550 & hvy Wt. $>5$ tons \\
\hline TRUCK CARGO: TACTICAL 8X8 HEAVY EXPANDED MOBILITY W/MED CRANE & 4 & GMC C550 & \\
\hline TRUCK CARGO: HEAVY PLS TRANSPORTER 15-16.5 TON 10X10 & 43 & M923A2(5-ton) & \\
\hline TRUCK CARGO: HEAVY PLS TRANSPORTER 15-16.5 TON 10X10 W/MHE W/E & 12 & M923A2(5-ton) & \\
\hline TRUCK CARGO: MTV W/E W/W & 1 & HMMWV & \\
\hline TRUCK TANK: FUEL SERVICING 2500 GALLON 8X8 HEAVY EXP MOB W/WINCH & 6 & M923A2(5-ton) & \\
\hline TRUCK CARGO: 4X4 LMTV W/E & 23 & HMMWV & \\
\hline TRUCK CARGO: 4X4 LMTV W/E W/W & 7 & HMMWV & \\
\hline TRUCK CARGO: MTV LWB W/E & 1 & HMMWV & \\
\hline TRUCK CARGO: MTV W/E & 50 & HMMWV & \\
\hline TRUCK: CARGO & 55 & HMMWV & \\
\hline TRUCK TRACTOR: MTV W/E & 26 & GMC G20 VAN & med. Wt 2.5-5 tons \\
\hline TRUCK TRACTOR: MTV W/E W/W & 1 & GMC G20 VAN & med. Wt 2.5-5 tons \\
\hline TRUCK UTILITY: CARGO/TROOP CARRIER 1-1/4 TON 4X4 W/E (HMMWV) & 206 & HMMWV & \\
\hline TRUCK UTILITY: CARGO/TROOP CARRIER 1-1/4 TON 4X4 W/E W/W (HMMWV) & 4 & HMMWV & \\
\hline TRUCK UTILITY: EXPANDED CAPACITY 4X4 W/E HMMWV M1113 & 50 & HMMWV & \\
\hline TRUCK LIFT: FORK VARIABLE REACH ROUGH TERRAIN & 6 & HMMWV & \\
\hline TRUCK TANK: FUEL SERVICING 2500 GALLON 8X8 HEAVY EXP MOB & 41 & M923A2(5-ton) & \\
\hline TRUCK TRACTOR: LET 6 X6 66000 GVW W/W C/S & 4 & 1 FREIGHTLINER & \\
\hline TRUCK UTILITY: ARMT CARRIER ARMD 1-1/4 TON 4X4 W/E (HMMWV) & 15 & HMMWV & \\
\hline TRUCK UTILITY: ARMT CARRIER ARMD 1-1/4 TON 4X4 W/E W/W (HMMWV) & 2 & HMMWV & \\
\hline TRUCK UTILITY: EXPANDED CAPACITY UP ARMORED HMMWV 4X4 W/E & 44 & HMMWV & \\
\hline TRUCK VAN: EXPANSIBLE MTV W/E & 6 & GMC G20 VAN & med. Wt $2.5-5$ tons \\
\hline TRUCK VAN: LMTV W/E & 18 & GMC G20 VAN & med. Wt $2.5-5$ tons \\
\hline TRUCK WRECKER: MTV W/E W/W & 4 & GMC C5500 & hvy wt. >5tons \\
\hline TRUCK WRECKER: TACTICAL 8X8 HEAVY EXPANDED MOBILITY W/WII & 10 & GMC C5500 & hvy wt. >5tons \\
\hline
\end{tabular}


Table A.1. (contd)

\begin{tabular}{|c|c|c|c|}
\hline POWER SUPPLY VEHICLE: HYP-57/TSEC & 47 & HMMWV & \\
\hline $\begin{array}{l}\text { AUGER EARTH BOOM MOUNTED: HYD SMALL EMPLACEMENT EXCAVATOR } \\
\text { (SEE) }\end{array}$ & 2 & GMC C5500 & \\
\hline FIRE SUPPORT TEAM VEHICLE: BRADLEY (BFIST) & 11 & 1 FREIGHTLINER & $58000 \mathrm{lbs} / 26300 \mathrm{~kg}$ \\
\hline Total Wheeled Vehicles & 758 & & \\
\hline \multicolumn{4}{|l|}{ Tracked Vehicle } \\
\hline RECOVERY VEHICLE FULL TRACKED: MEDIUM & 13 & 2 FREIGHTLINERS & medium' \\
\hline RECOVERY VEHICLE FULL TRACKED: HEAVY M88A2 & 13 & 3 FREIGHTLINERS & $\begin{array}{l}\text { HERCULES } 70 \\
\text { TONS/63500KG }\end{array}$ \\
\hline TANK COMBAT FULL TRACKED: 120MM GUN M1A2 & 58 & 3 FREIGHTLINERS & ABRAMS 68.4 TONS \\
\hline $\begin{array}{l}\text { TRACTOR FULL TRACKED HIGH SPEED: ARMORED COMBAT EARTHMOVER } \\
\text { (ACE) }\end{array}$ & 6 & 1 FREIGHTLINER & $\begin{array}{l}\text { COMBAT WEIGHT } \\
55000 \mathrm{lbs} / 24950 \mathrm{~kg}\end{array}$ \\
\hline CARRIER AMMUNITION: TRACKED VEHICLE (CATV) & 16 & 1 FREIGHTLINER & $\begin{array}{l}\text { M992 } 28.75 \\
\text { tons/57500lbs/26000kg }\end{array}$ \\
\hline CARRIER 120 MILLIMETER MORTAR: SELF PROPELLED ARMORED & 14 & M923A2 (5 ton) & $\sim 12,000 \mathrm{~kg}$ \\
\hline CARRIER ARMORED COMMAND POST: FULL TRACKED & 35 & M977 HEMMET & $\begin{array}{l}\text { M113 FAMILY } \\
40000 \mathrm{lbs} / 18000 \mathrm{~kg}\end{array}$ \\
\hline CARRIER PERSONNEL FULL TRACKED: ARMORED (RISE) & 49 & M923A2 (5 ton) & $\begin{array}{l}\text { M113A3 APC } \\
27180 \mathrm{lbs} / 12300 \mathrm{~kg}\end{array}$ \\
\hline FIGHTING VEHICLE: FULL TRACKED INFANTRY HI SURVIVABILITY (IFV) & 18 & 1 FREIGHTLINER & $\begin{array}{l}\text { M2 Bradley } \\
50000 \text { lbs/22700KG }\end{array}$ \\
\hline FIGHTING VEHICLE: FULL TRACKED INFANTRY (IFV) M2A3 & 61 & 1 FREIGHTLINER & $\begin{array}{l}\text { Bradley } \\
58000 \mathrm{lbs} / 26304 \mathrm{~kg}\end{array}$ \\
\hline HOWITZER MEDIUM SELF PROPELLED: & 16 & 1 FREIGHTLINER & $\begin{array}{l}\text { M109 A6 Paladin } \\
60000 \mathrm{lbs} / 27211 \mathrm{~kg}\end{array}$ \\
\hline FIGHTING VEHICLE: FULL TRACKED CAVALRY (CFV) M3A3 & 29 & 1 FREIGHTLINER & $\begin{array}{l}\text { Bradley } \\
58000 \mathrm{lbs} / 26304 \mathrm{~kg}\end{array}$ \\
\hline RECOVERY VEHICLE FULL TRACKED: MEDIUM & 13 & 2 FREIGHTLINERS & $\begin{array}{l}\text { medium' - between } \\
\text { Bradley and Hercules }\end{array}$ \\
\hline RECOVERY VEHICLE FULL TRACKED: HEAVY M88A2 & 13 & 3 FREIGHTLINERS & $\begin{array}{l}\text { Hercules } 70 \\
\text { tons } / 63500 \mathrm{~kg}\end{array}$ \\
\hline Total Tracked Vehicles & 354 & & \\
\hline
\end{tabular}




\title{
Appendix B
}

\author{
Wind Fields
}




\section{Appendix B: Wind Fields}

This appendix contains screen captures of the 10-m above ground wind fields predicted by the CALMET module within DUSTRAN. Wind fields are shown at 0700, 1000, 1300, 1600, and 1900 MST for the 6 days included in the current simulations (April 25, 26, 27, 28, 29 and 30, 2005). Header captions within each figure indicate the day and time represented by a given plot. The arrow on each vector indicates

wind direction while the scaling of vector length indicates wind speed. A reference vector whose length represents a wind speed of $3 \mathrm{~m} / \mathrm{s}$ is shown on each plot. 


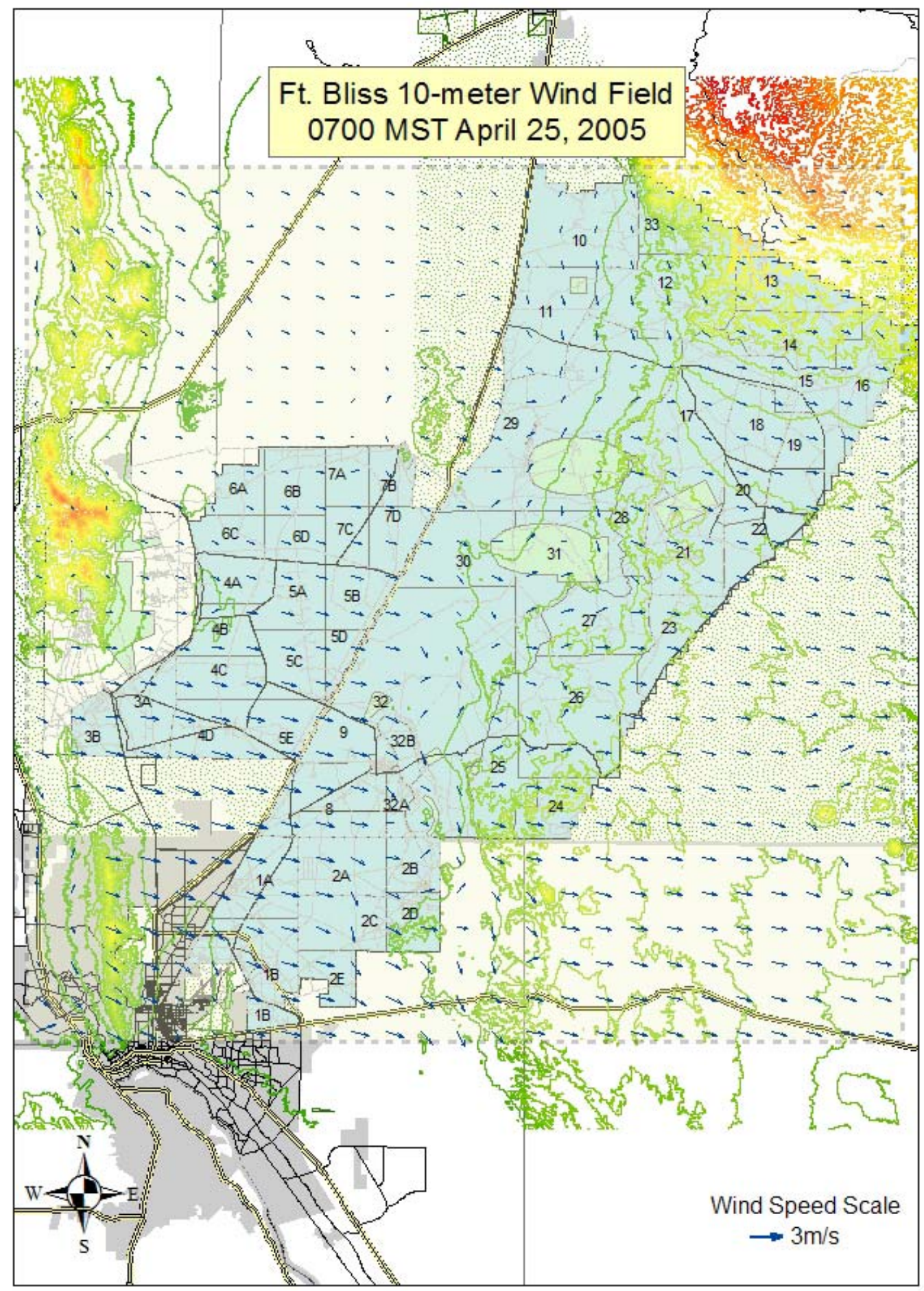




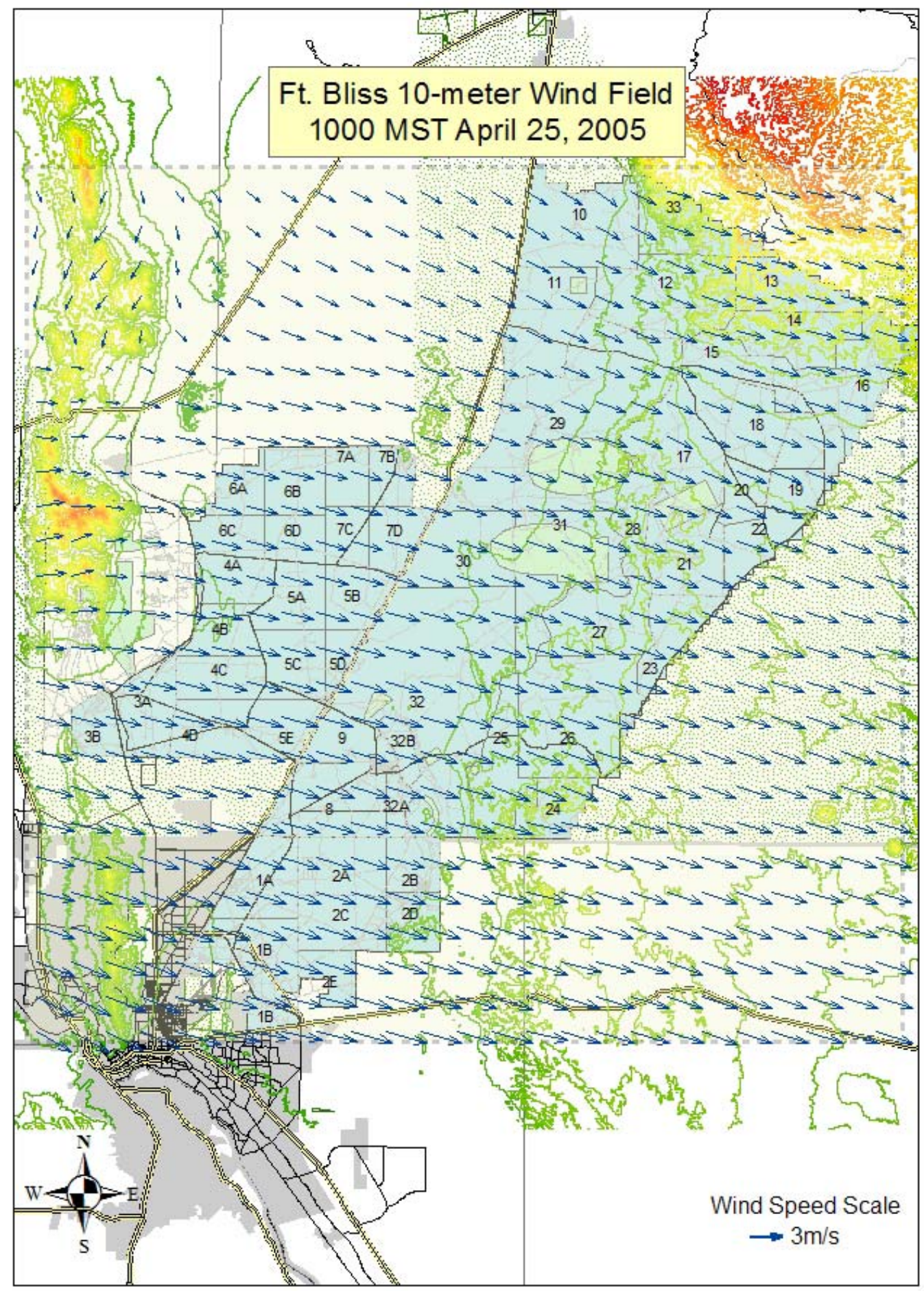

B. 3 







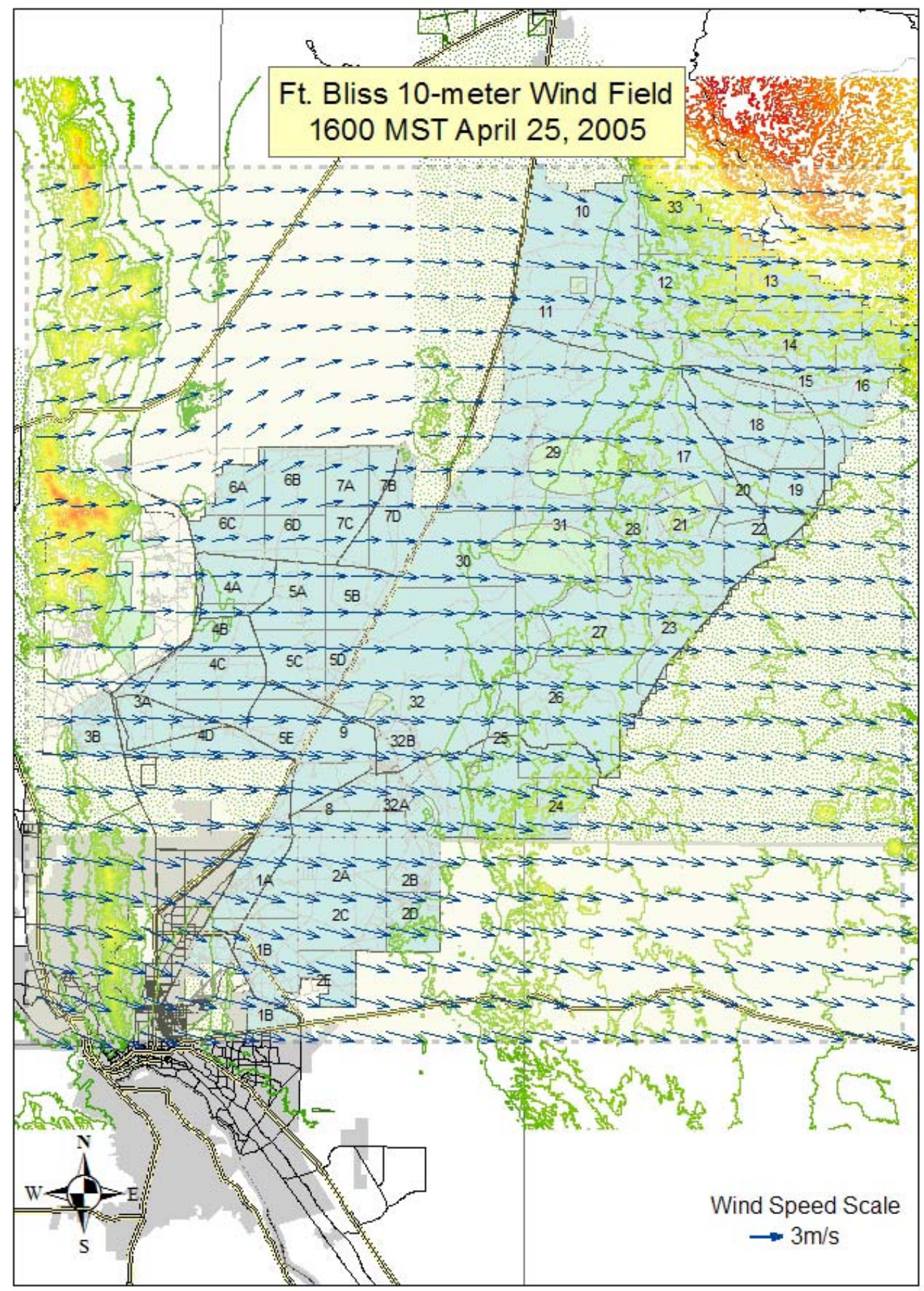




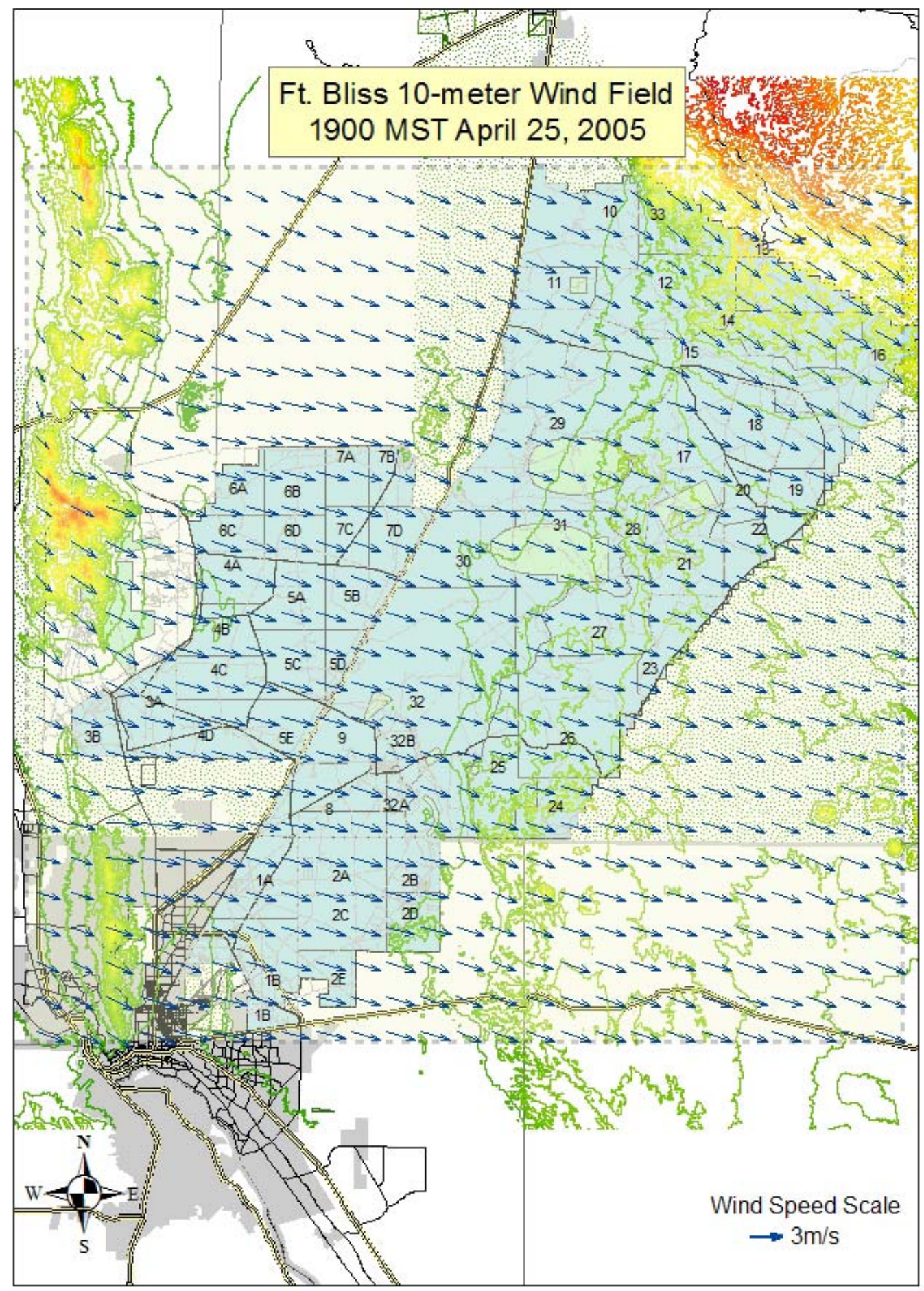




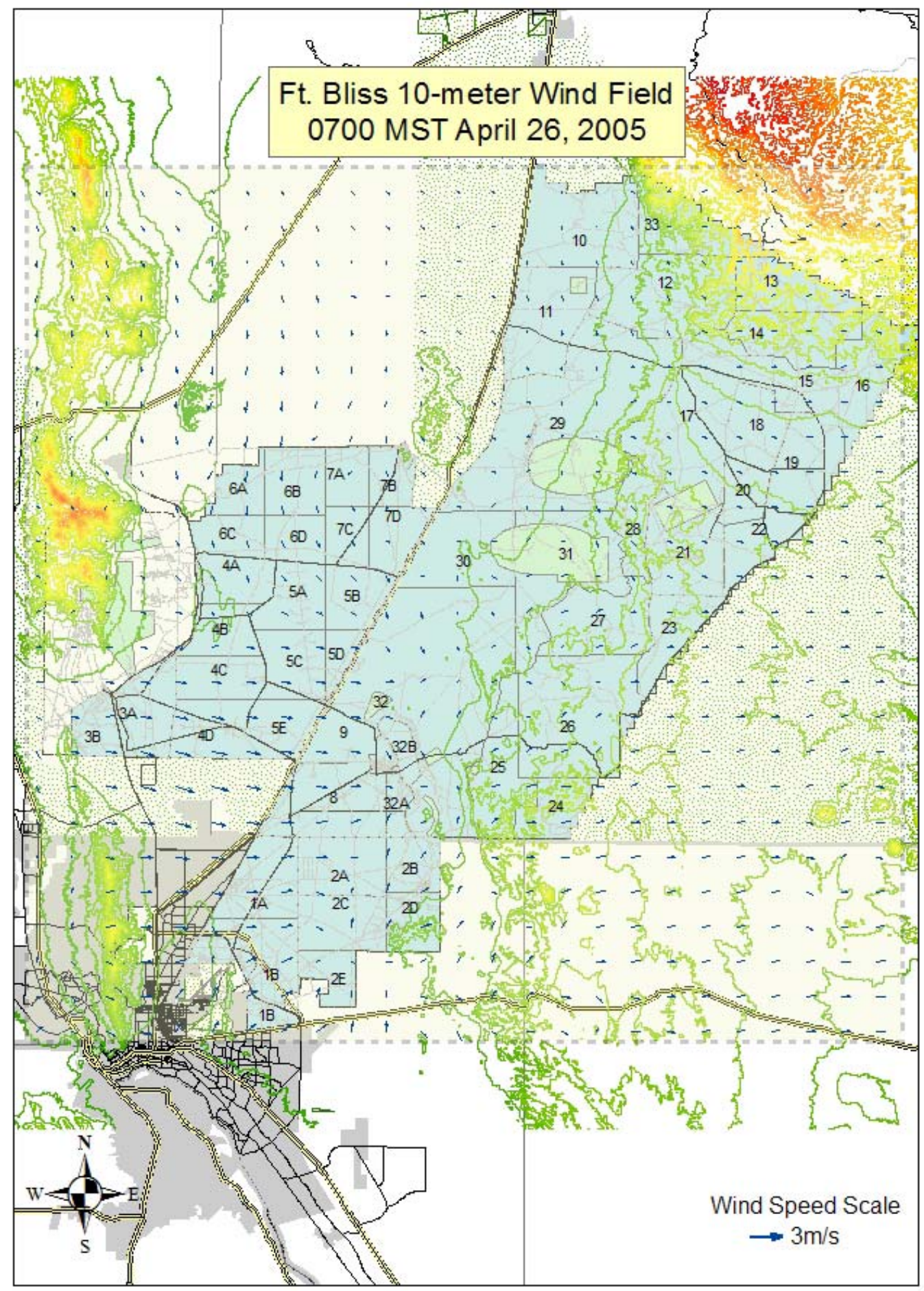

B.7 


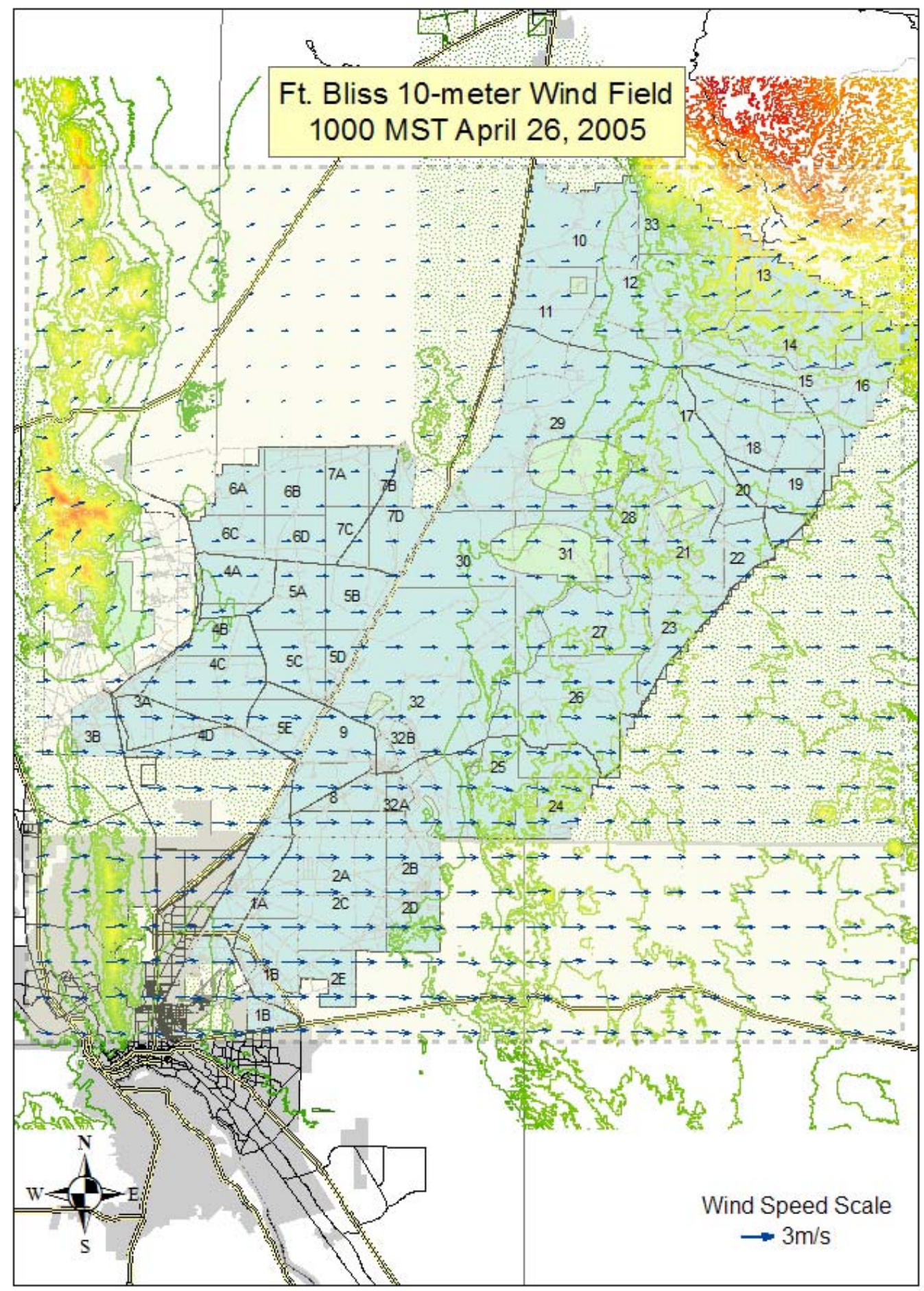




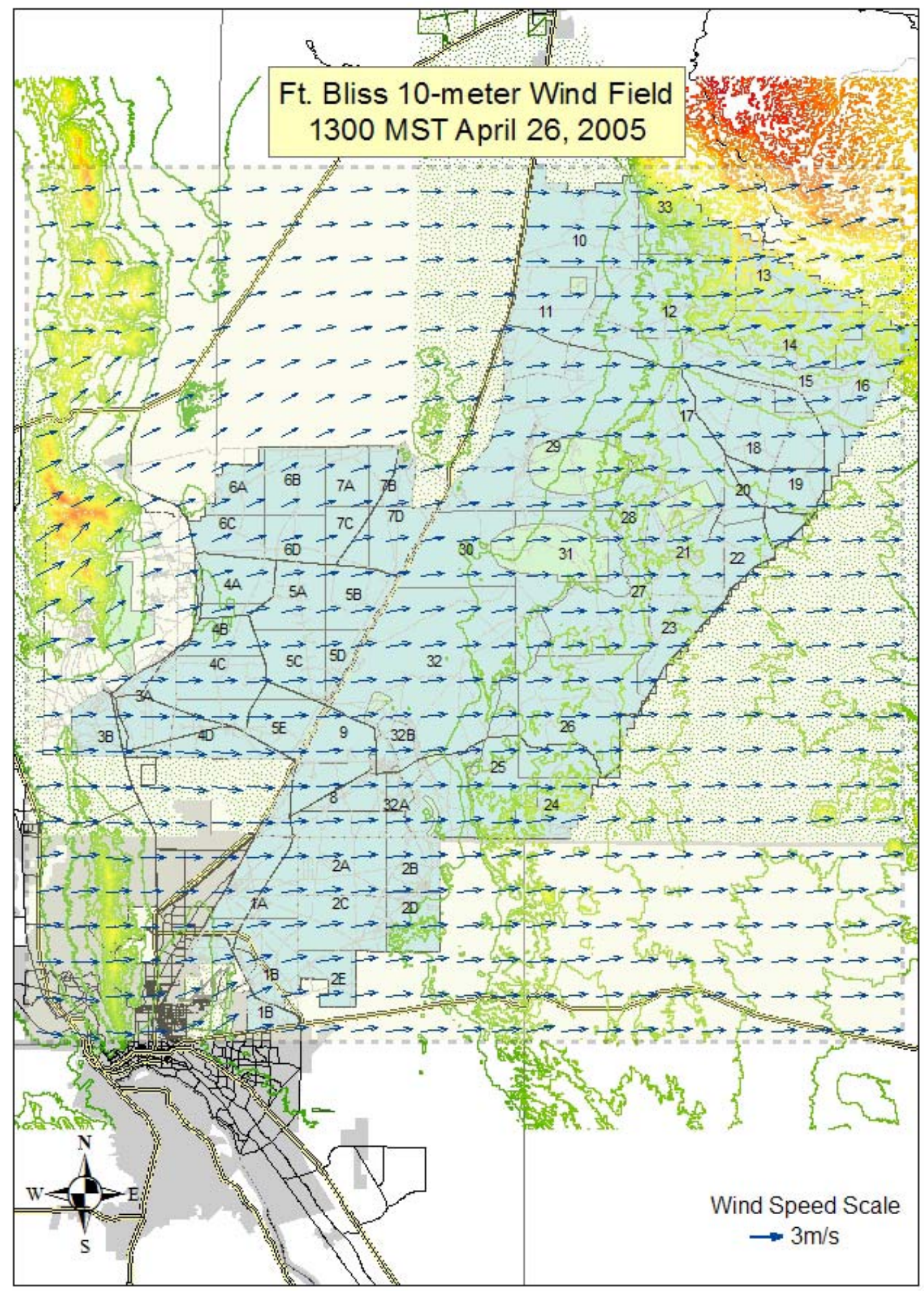




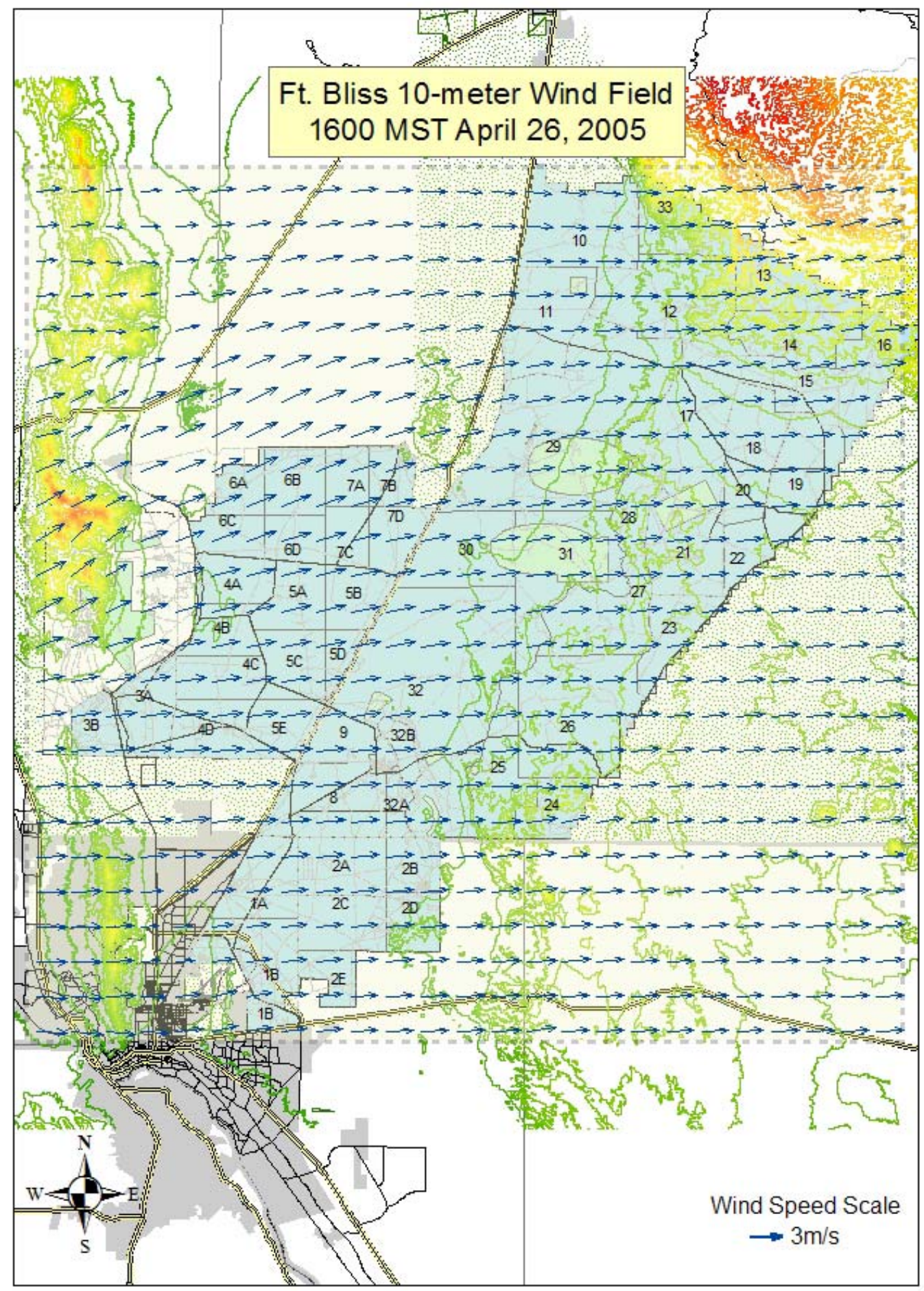









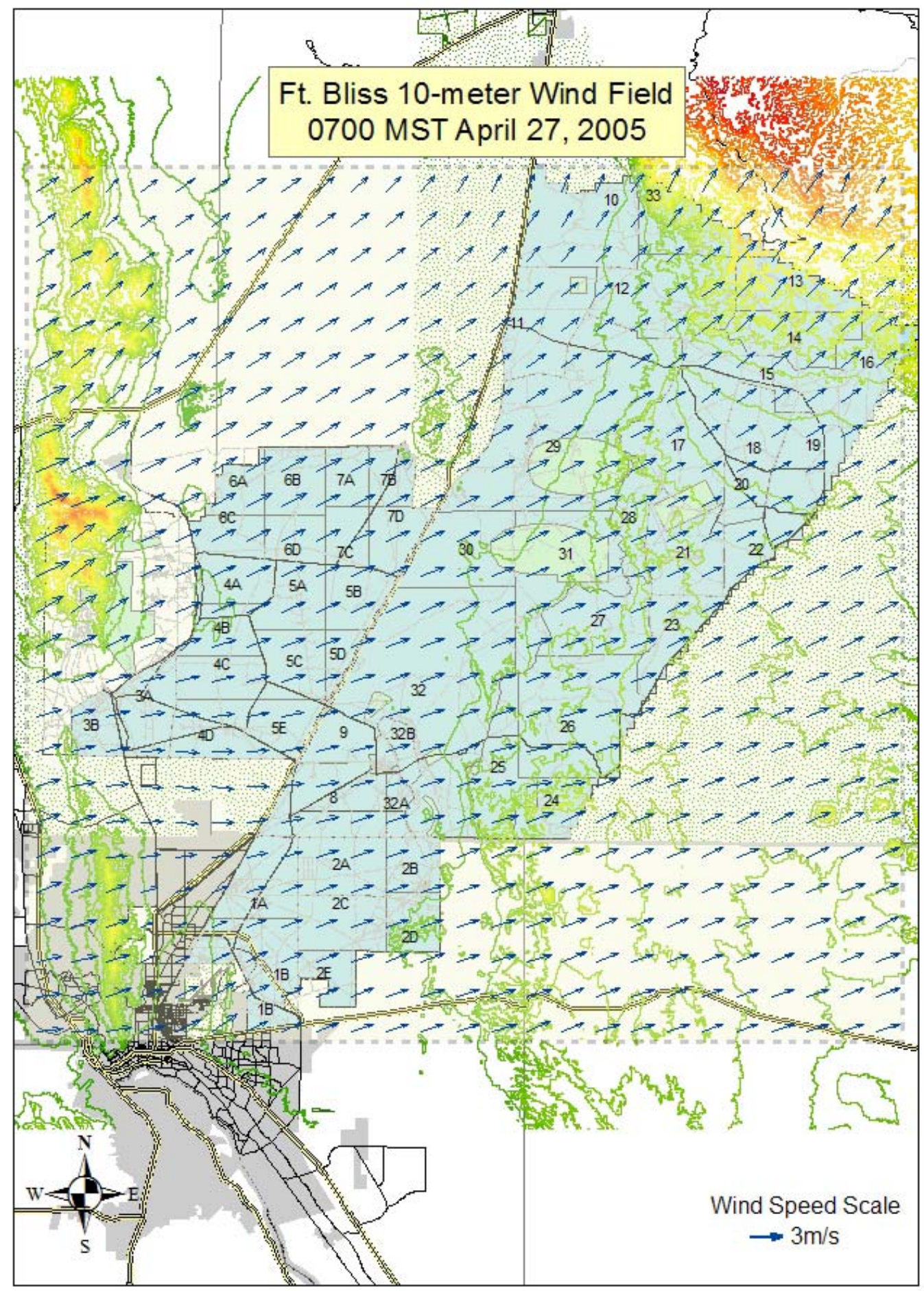




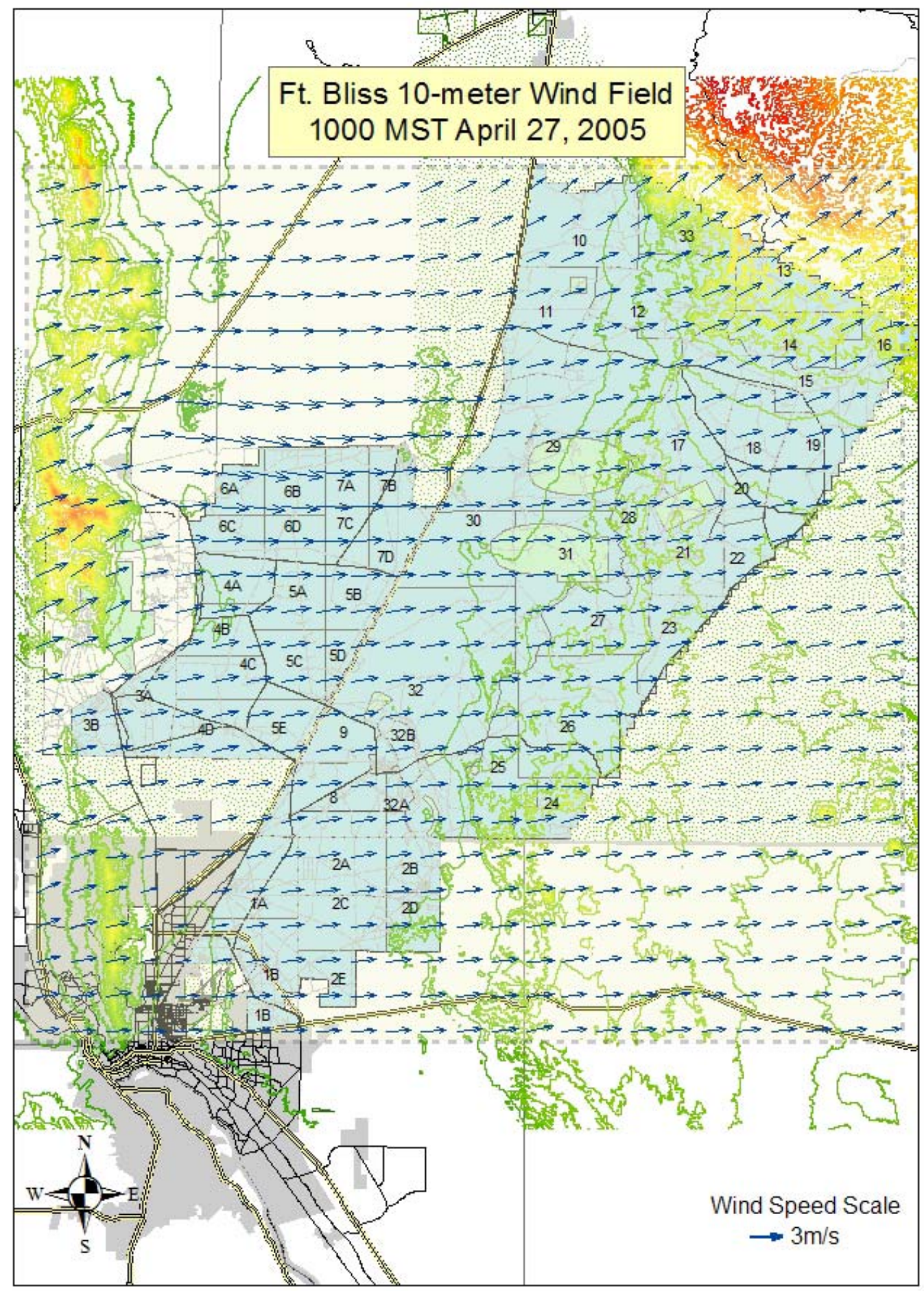




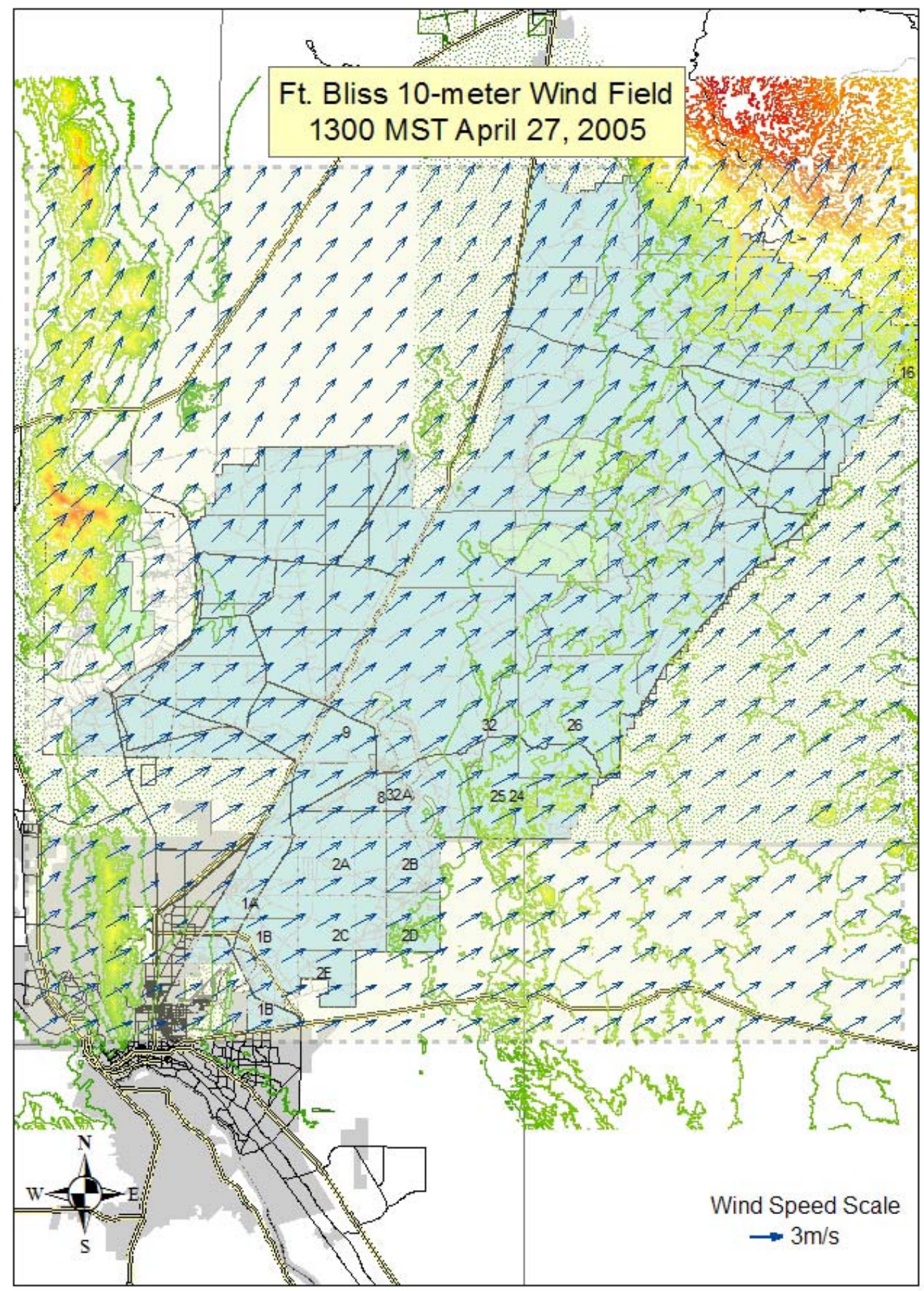




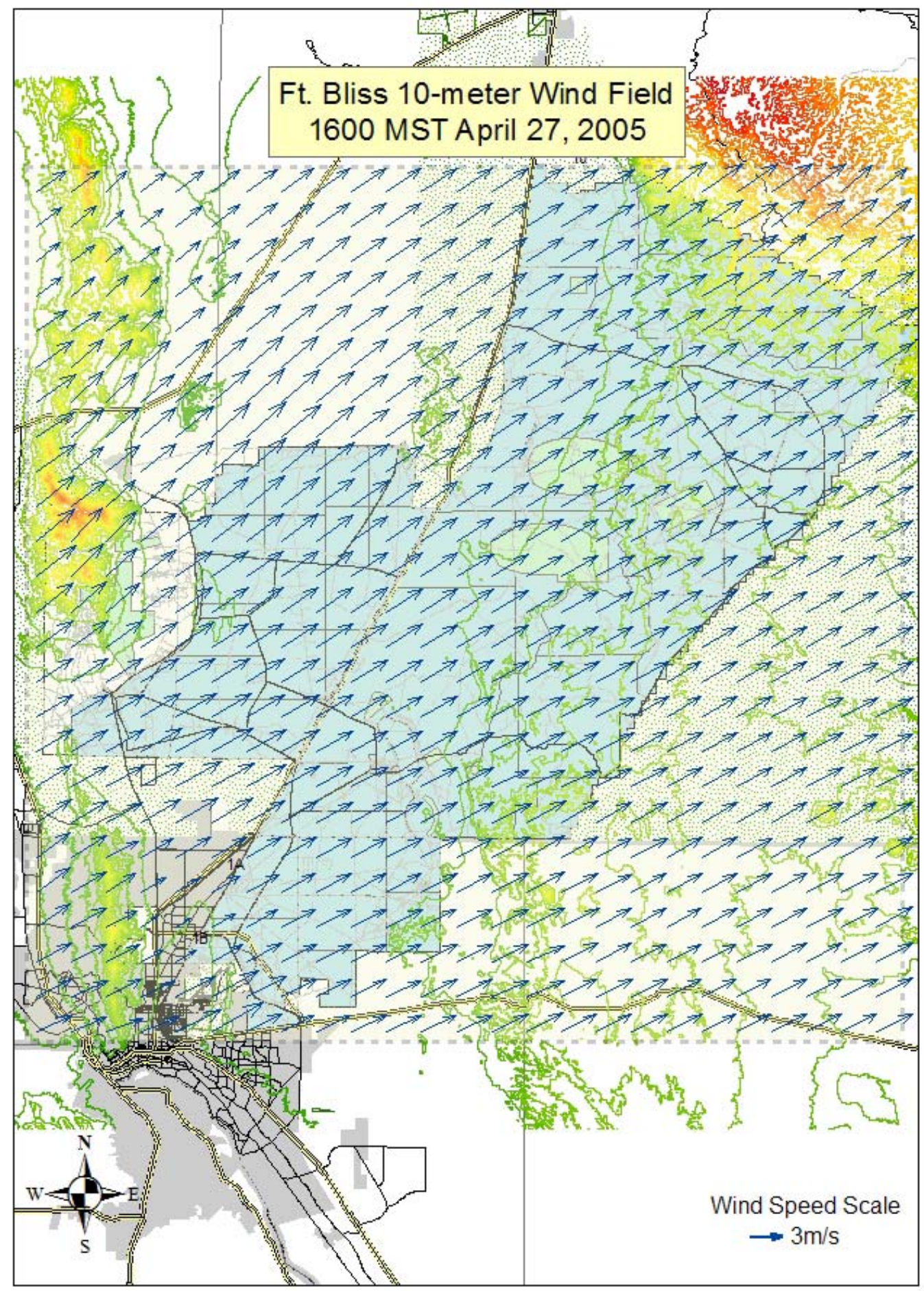

B.15 


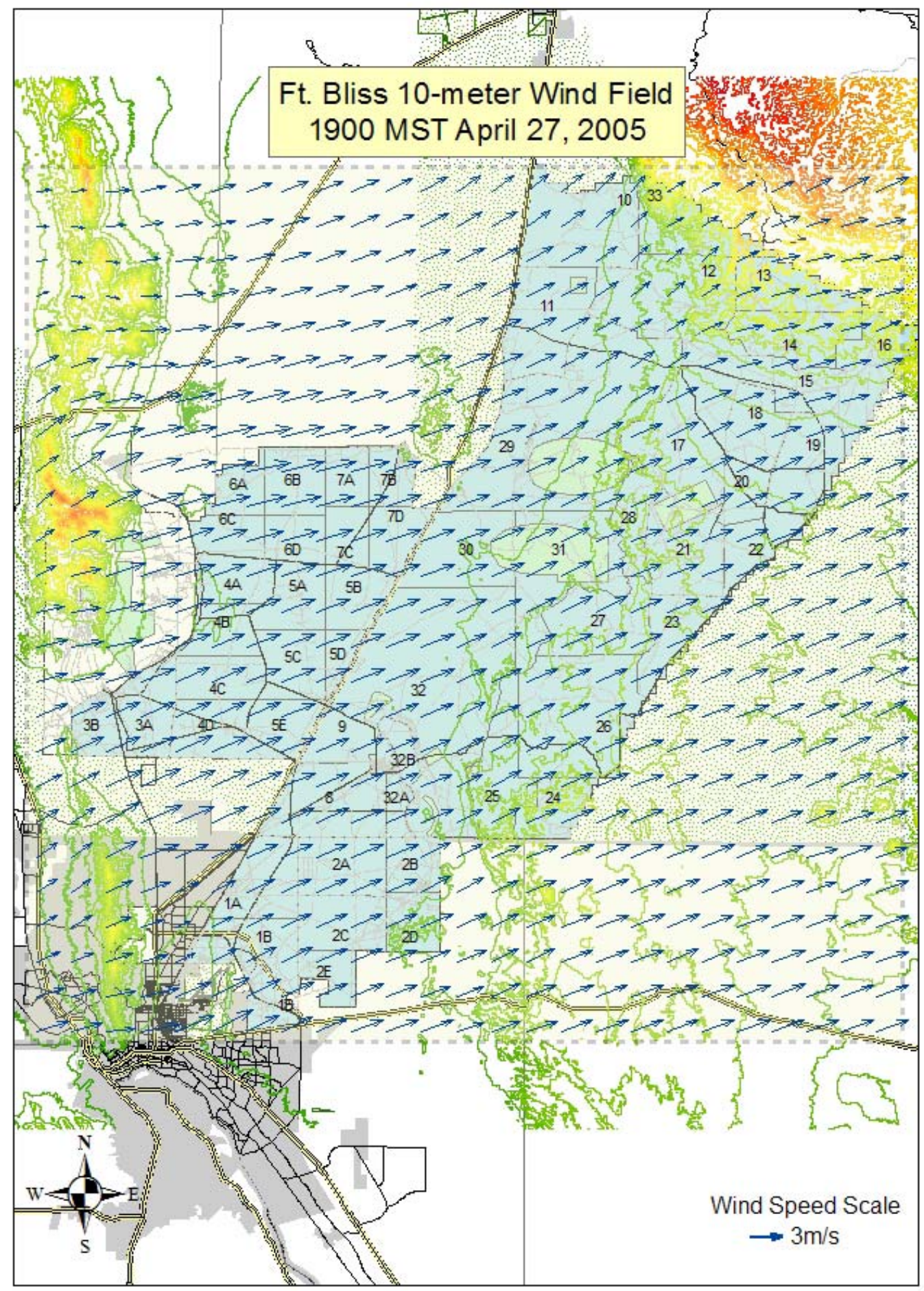









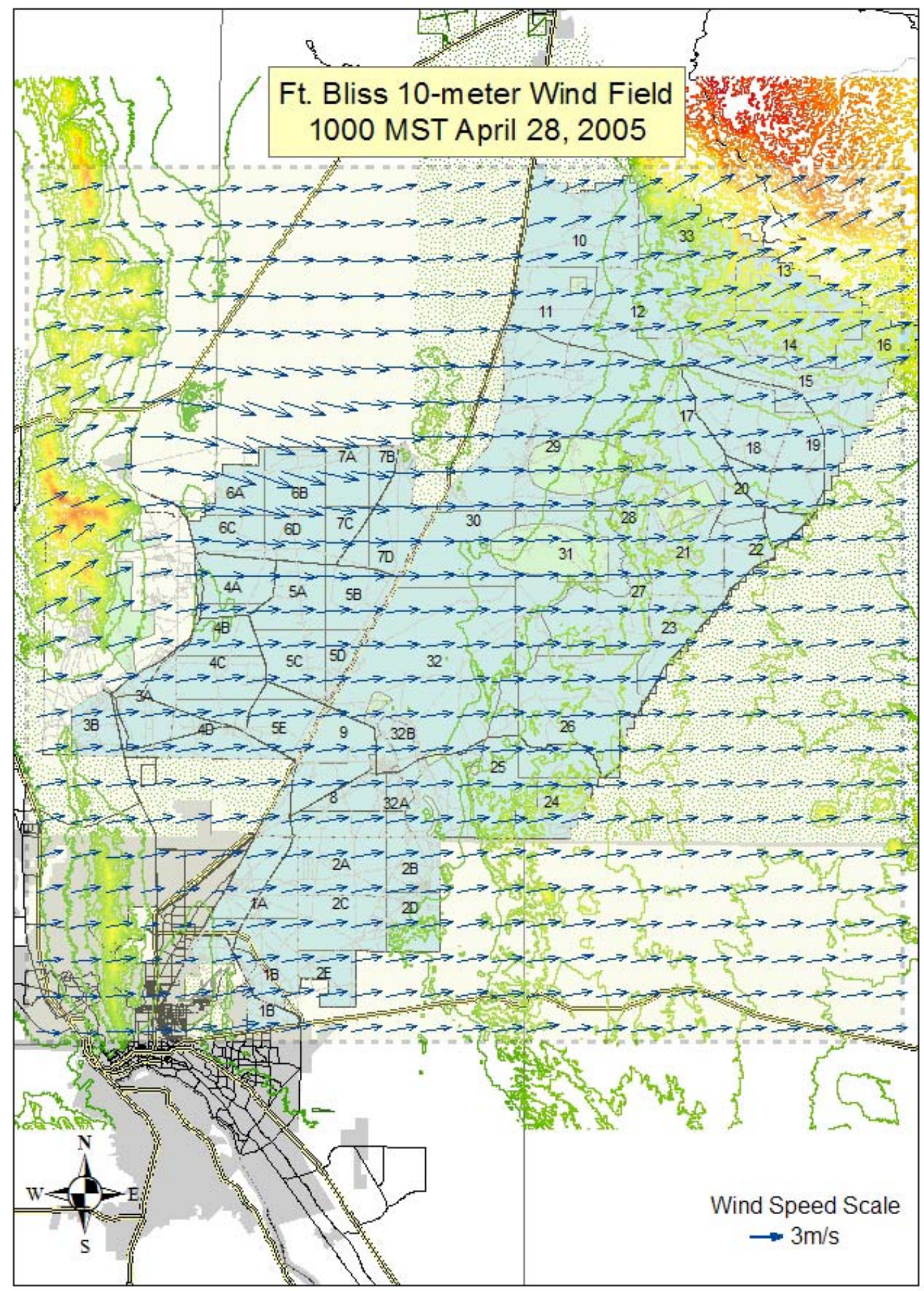




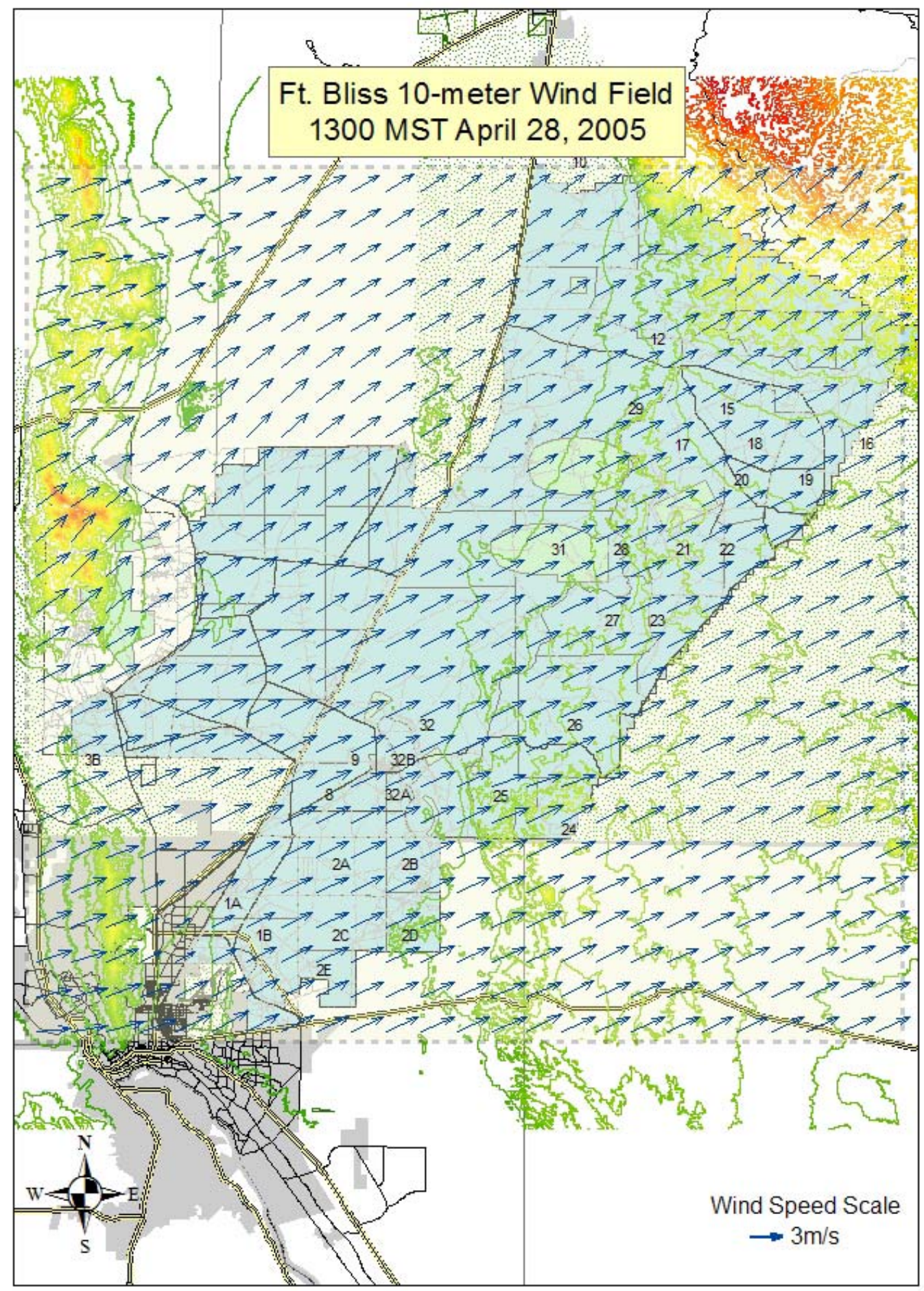














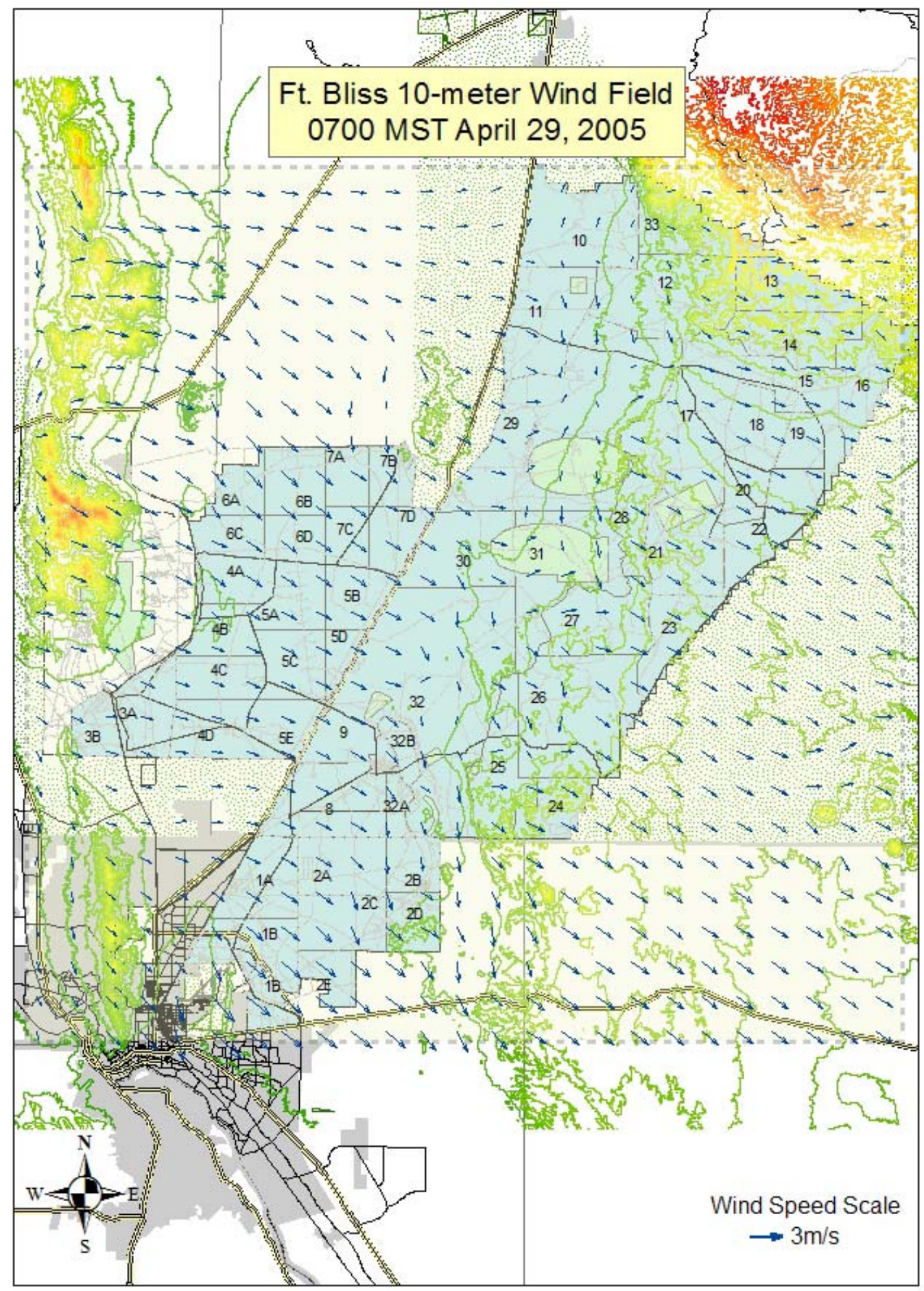




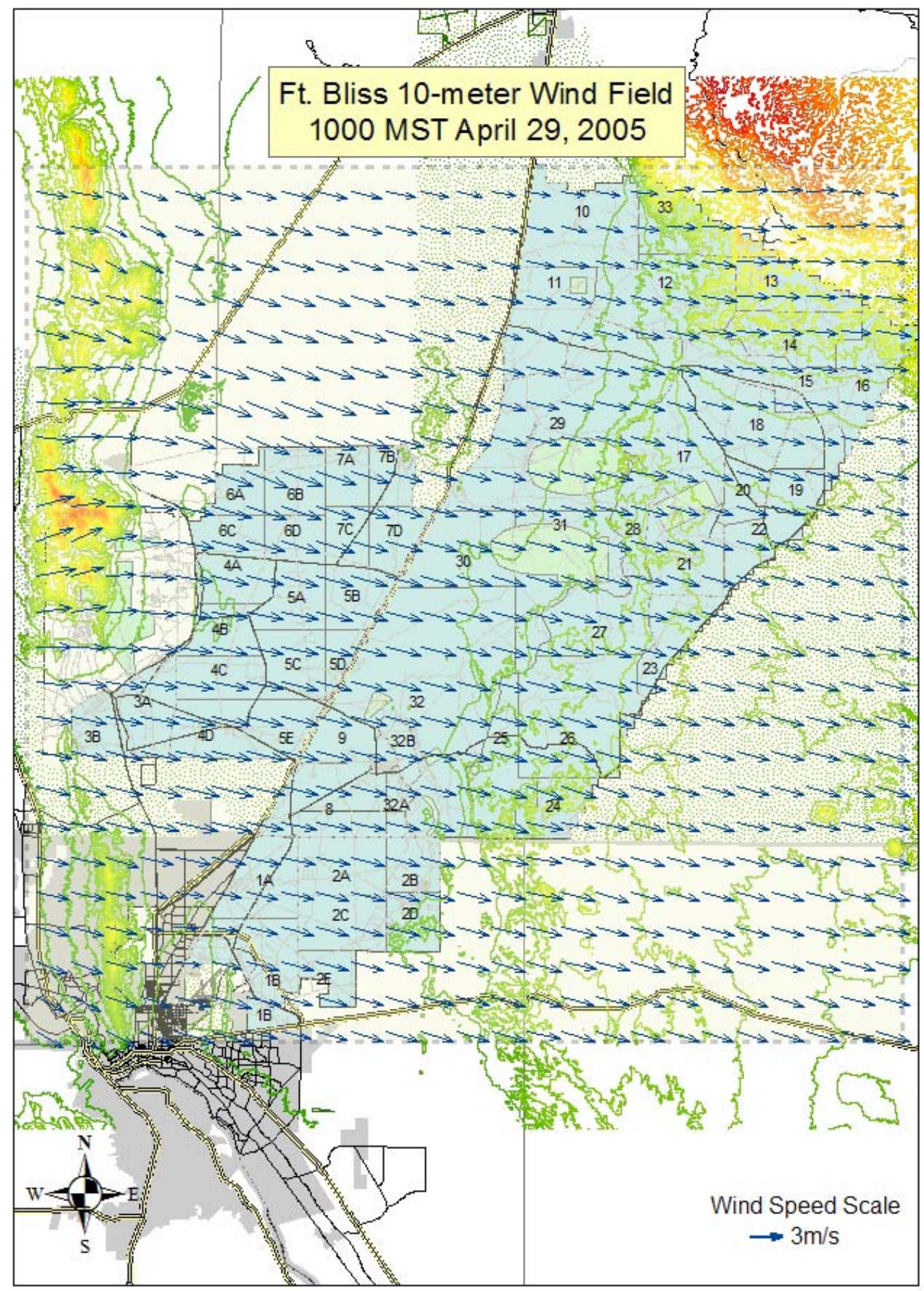




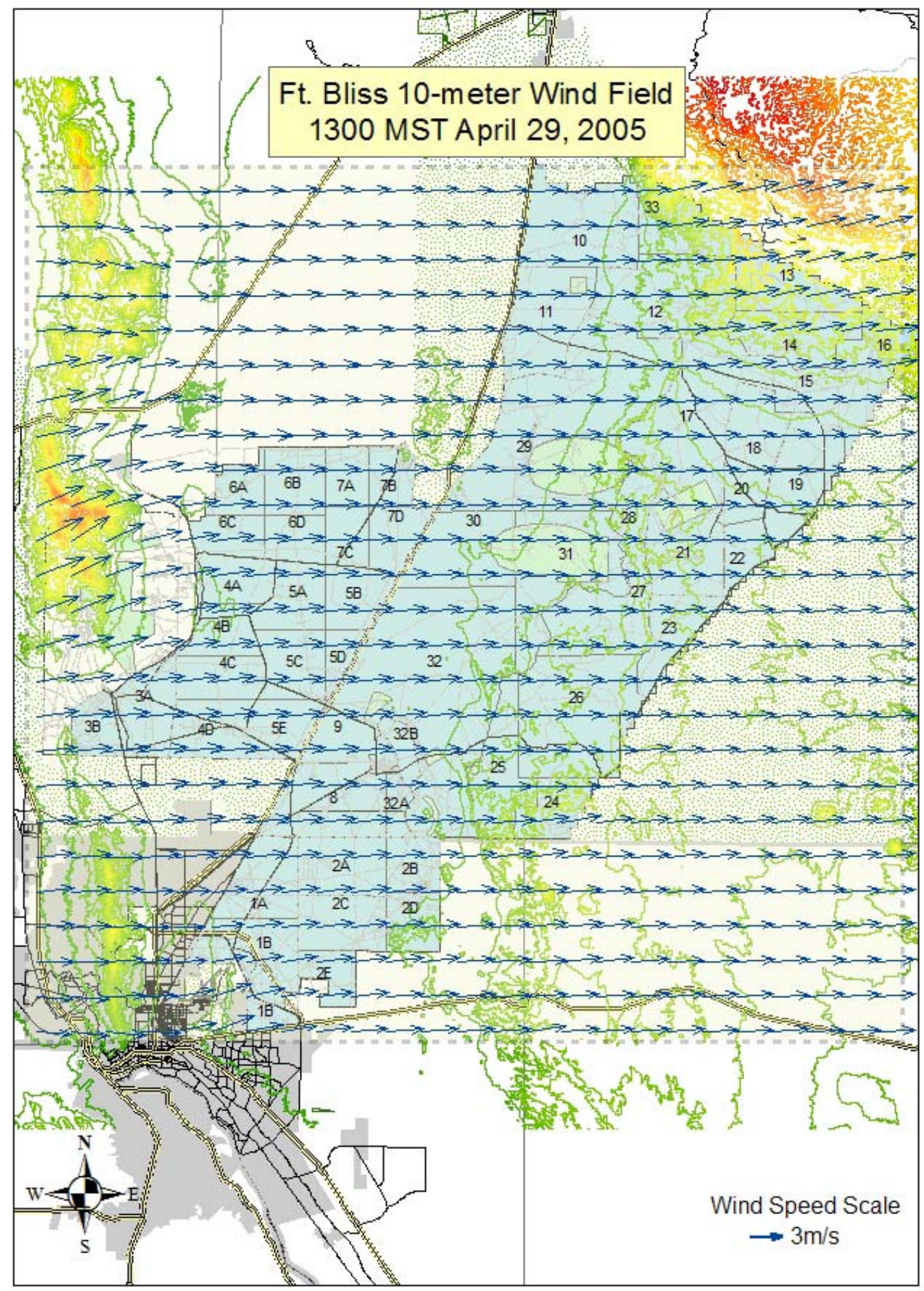




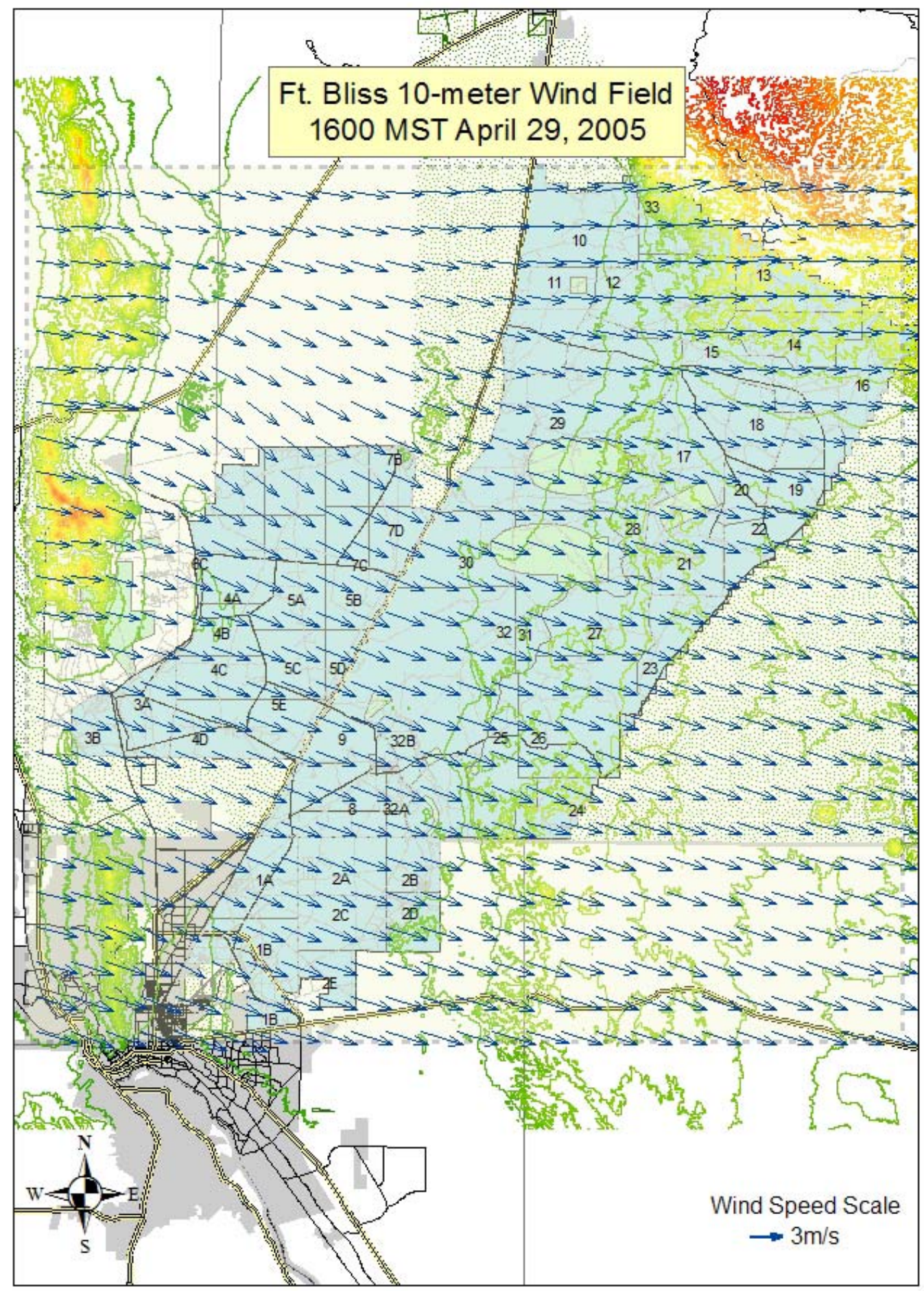




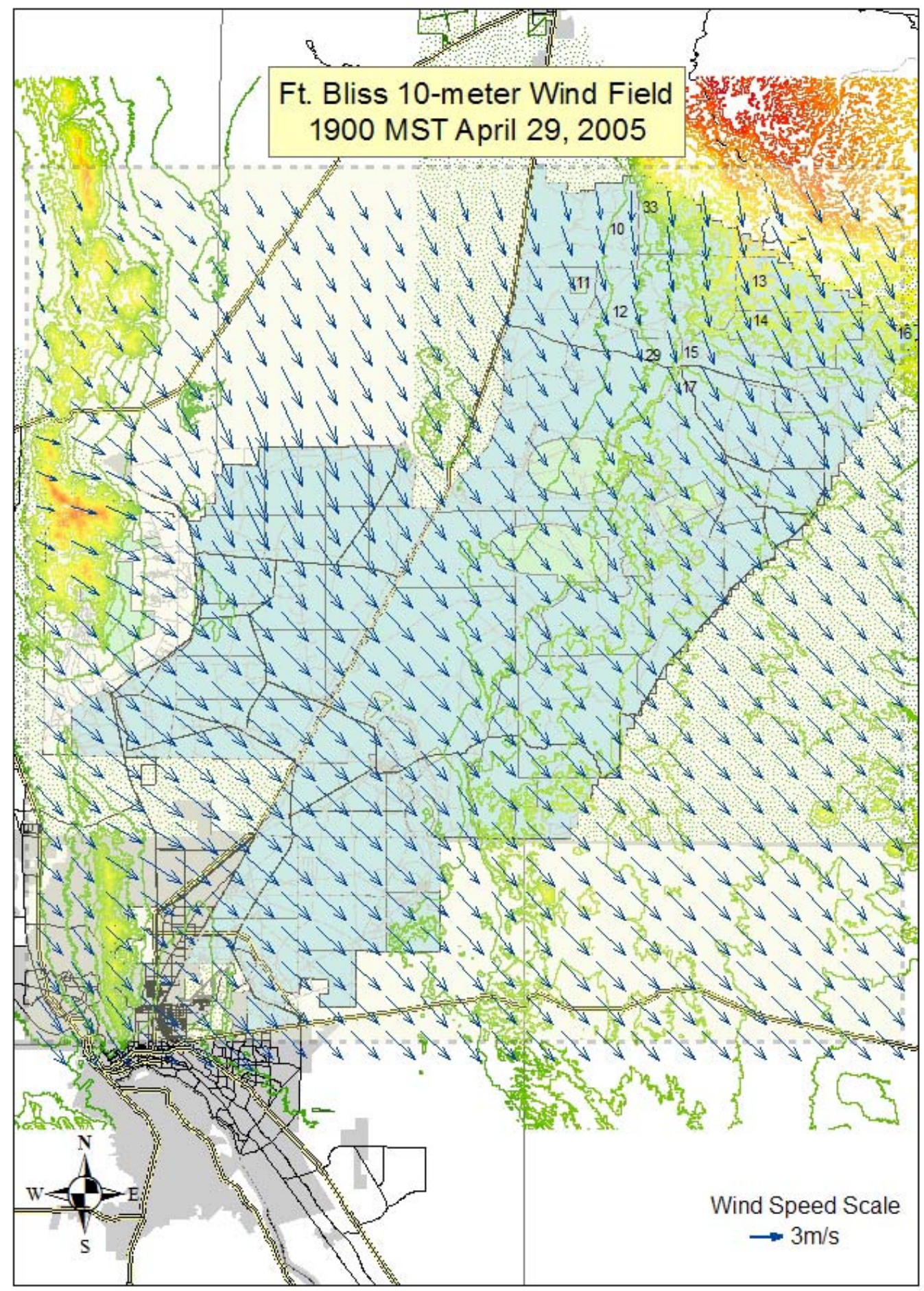




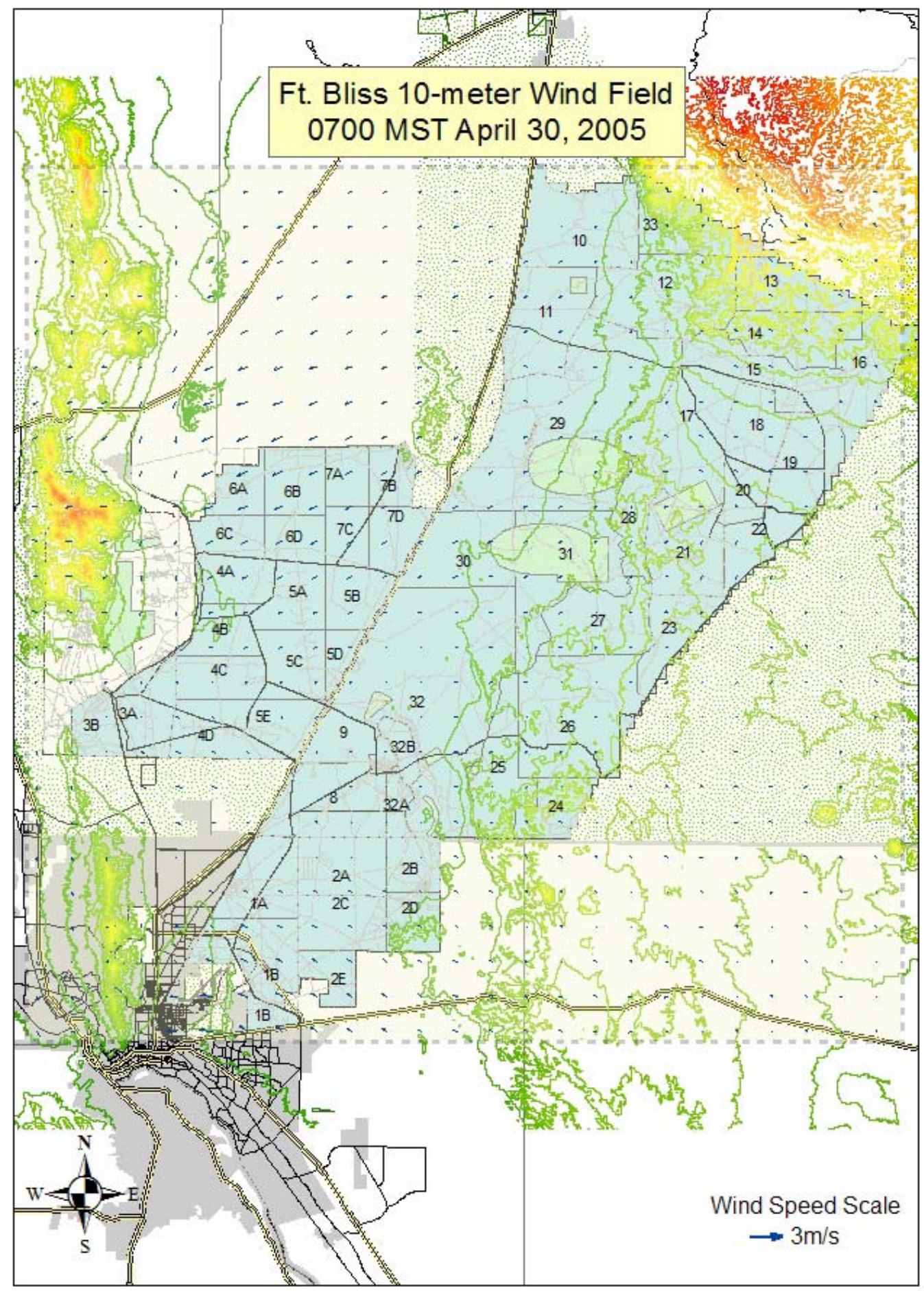














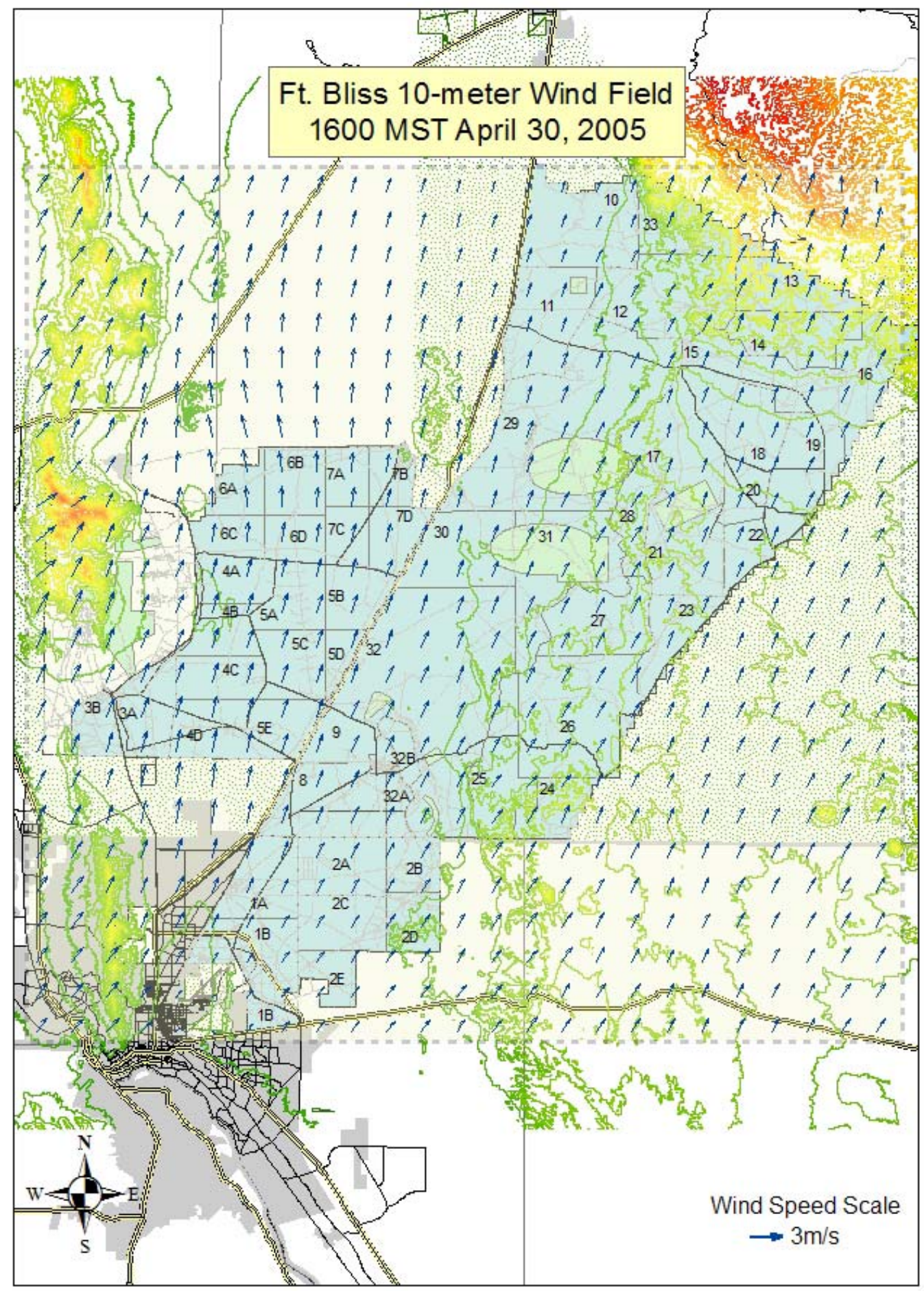









\section{Appendix C}

Top 50 tables 


\section{Appendix C: Top 50 Tables}

The following tables list the maximum 50 ground-level 24-hour-average concentration contributions in the modeling domain calculated by CALPUFF for the Full Training scenario. There is a separate table for each day in the April 25-30, 2005, time period. Tables from simulations using the 10-hour activity duration are given first, followed by tables from simulations using the compressed 1-hour activity duration. Fields within each table list the year, Julian day, time, receptor location in terms of an (i,j) grid cell location, type, concentration contribution in grams per cubic meter, and the Universal Transverse Mercator (UTM) coordinates of the grid cell center where this concentration contribution occurs. Because these are 24-hour averages, not the maximum for a specific hour, the hour field contains the dummy value of " 2300 " because this is the start of the last hour included in the averaging period.

Figures with $\mathrm{PM}_{10}$ concentrations in the main body of the report are in units of micrograms per cubic meter. Multiply the concentration values in the following Top 50 tables by 1,000,000 for direct comparison with values in the figures. 


\section{APRIL 25, 2005 CALPUFF CONCENTRATIONS FOR PM10 10 HOUR ACTIVITY DURATION \\ TOP-50 24 HOUR AVERAGE CONCENTRATION VALUES ( $/ \mathrm{m} / * 3)$}

YEAR DAY TIME(HHMM) RECEPTOR TYPE CONCENTRATION COORDINATES (km)

\begin{tabular}{|c|c|c|c|c|c|}
\hline & 00 & $3,23) \mathrm{G}$ & & & \\
\hline & & 31) G & & & \\
\hline & 0 & 'רכי & & & \\
\hline 05 & 300 & ? & & & \\
\hline 05 & 300 & $6)$ & & & \\
\hline 05 & 300 & SU) & & & \\
\hline 05 & 300 & $4,26) G$ & & & \\
\hline 05 & 300 & , 21) G & & & \\
\hline & 300 & 29) & & & \\
\hline 05 & 00 & , 25) G & & & \\
\hline 05 & 300 & & & & \\
\hline 05 & 300 & , 20) & & & \\
\hline 05 & 300 & & & & \\
\hline 05 & 300 & & & & \\
\hline 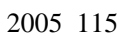 & 300 & & & & \\
\hline 51 & 300 & & & & \\
\hline & 300 & 24) & & & \\
\hline 5 & 300 & & & & \\
\hline 05 & 300 & & & & \\
\hline 05 & 300 & & & & \\
\hline 0 & 300 & & & & \\
\hline 05 & 300 & 30) & & & \\
\hline 51 & 300 & & & & \\
\hline & 300 & & & & \\
\hline & 300 & & & & \\
\hline 5 & 300 & & & & \\
\hline 5 & 300 & & & & \\
\hline 05 & O & באר & & & \\
\hline 05 & 300 & & & & \\
\hline & & & & & \\
\hline 05 & 300 & & & & \\
\hline & 2 & & & & \\
\hline 5 & & & & & \\
\hline 5 & 0 & & & & \\
\hline - & 300 & & & & \\
\hline & & & & & \\
\hline 005 & & & & & \\
\hline & & & & & \\
\hline & & & & & \\
\hline & & & & & \\
\hline & 2300 & & & & \\
\hline 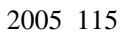 & & & & & \\
\hline 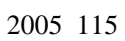 & 2300 & , 27) & & & .000 \\
\hline & & t & & & \\
\hline & & & & & \\
\hline & & & & & \\
\hline & & & & & \\
\hline & 2300 & & & & \\
\hline 200 & 2300 & & & $4 t$ & .000 \\
\hline 005115 & 00 & 24, & 1.1876E-05 & 396. & 3567.00 \\
\hline
\end{tabular}


APRIL 26, 2005 CALPUFF CONCENTRATIONS FOR PM10 10 HOUR ACTIVITY DURATION

TOP-50 24 HOUR AVERAGE CONCENTRATION VALUES ( $\left.\mathrm{g} / \mathrm{m}^{* * 3}\right)$

YEAR DAY TIME(HHMM) RECEPTOR TYPE CONCENTRATION COORDINATES (km)

\begin{tabular}{|c|c|c|c|c|c|}
\hline & & 23) $\mathrm{G}$ & & & \\
\hline 116 & 300 & $2,20) \mathrm{G}$ & & & \\
\hline 16 & 00 & 22) & & & \\
\hline 16 & 00 & $2,21) \mathrm{G}$ & & & \\
\hline & 300 &  & & & \\
\hline 05 & 300 & $15,26) \mathrm{G}$ & & & \\
\hline & 300 & 26) & & & \\
\hline 05 & 300 & $16,29) \mathrm{G}$ & & & \\
\hline 16 & 300 & $4,24) \mathrm{G}$ & & & \\
\hline & 300 & 6) G & & & \\
\hline 16 & 300 & $3,23) \mathrm{G}$ & & & \\
\hline & 300 & & & & \\
\hline 6 & 2300 & , 27) G & & & \\
\hline & 2300 & & & & \\
\hline & 2300 & 28) G & & & \\
\hline 16 & 300 & (3) & & & \\
\hline & 300 & 7) $\mathrm{G}$ & & & \\
\hline 16 & 2300 & 9) G & & & \\
\hline & 2300 & & & & \\
\hline & 2300 & & & & \\
\hline & 2300 & & & & \\
\hline 6 & 300 & & & & \\
\hline 5116 & 2300 & 29) G & & & \\
\hline 16 & 2300 & & & & \\
\hline 16 & 300 & & & & \\
\hline 16 & 2300 & 3) & & & \\
\hline & 2300 & & & & \\
\hline & 2300 & & & & \\
\hline & 2300 & 1) & & & \\
\hline 16 & 2300 & 32) & & & \\
\hline & 2300 & & & & \\
\hline 16 & 2300 & & & & \\
\hline 16 & 2300 & 8) $\mathrm{G}$ & & & \\
\hline & 2300 & & & & \\
\hline & 2300 & & & & \\
\hline & 2300 & 0) & & & \\
\hline 16 & 2300 & 22) & & & \\
\hline & 300 & & & & \\
\hline & 00 & & & & \\
\hline & 2300 & & & & \\
\hline & 2300 & & & & \\
\hline & 2300 & & & & \\
\hline & 2300 & $19,32) \mathrm{G}$ & & & .000 \\
\hline & 2300 & -) & & & .000 \\
\hline & 2300 & 1) & & & \\
\hline & & & & & \\
\hline & & & & & \\
\hline & 2000 & & & & \\
\hline & 2300 & & E-05 & 398.000 & 571.000 \\
\hline & & & 5E-05 & 98.000 & 665.00 \\
\hline
\end{tabular}


APRIL 27, 2005 CALPUFF CONCENTRATIONS FOR PM10 10 HOUR ACTIVITY DURATION

TOP-50 24 HOUR AVERAGE CONCENTRATION VALUES ( $\left.\mathrm{g} / \mathrm{m}^{* * 3}\right)$

YEAR DAY TIME(HHMM) RECEPTOR TYPE CONCENTRATION COORDINATES (km)

\begin{tabular}{|c|c|c|c|c|c|}
\hline & & 32) G & & & \\
\hline 117 & 300 & $16,27) \mathrm{G}$ & & & \\
\hline 17 & 0 & 4, 24) & & & \\
\hline 17 & 00 & $8,31)$ & & & \\
\hline & 300 & ' & & & \\
\hline & 300 & $12,22)$ & & & \\
\hline & 300 & 25) & & & \\
\hline 17 & 300 & $15,29) \mathrm{G}$ & & & \\
\hline 17 & 300 & $13,26) \mathrm{G}$ & & & \\
\hline 17 & 300 & 3) G & & & \\
\hline 17 & 300 & , 33) G & & & \\
\hline 17 & 300 & & & & \\
\hline & 300 & , 32) G & & & \\
\hline 17 & 300 & & & & \\
\hline 17 & 2300 & 23) G & & & \\
\hline 17 & 300 & & & & \\
\hline 17 & 300 & 3) G & & & \\
\hline 17 & 2300 & 6) $\mathrm{G}$ & & & \\
\hline 7 & 2300 & & & & \\
\hline & 2300 & & & & \\
\hline & 300 & & & & \\
\hline & 300 & & & & \\
\hline 117 & 2300 & $(13,27) \mathrm{G}$ & & & \\
\hline 17 & 2300 & & & & \\
\hline 17 & 300 & G & & & \\
\hline 17 & 300 & G & & & \\
\hline & 2300 & & & & \\
\hline & 2300 & & & & \\
\hline & 00 & & & & \\
\hline 17 & 2300 & & & & \\
\hline 17 & 2300 & & & & \\
\hline 17 & 2300 & & & & \\
\hline 17 & 2300 & 0 & & & \\
\hline & 2300 & & & & \\
\hline & 2300 & & & & \\
\hline & 2300 & 7) $\mathrm{G}$ & & & \\
\hline 17 & 2300 & $5,8) \mathrm{G}$ & & 38 & \\
\hline & 300 & & & & \\
\hline & 00 & & & & \\
\hline & 2300 & & & & \\
\hline 117 & 2300 & & & & \\
\hline & 2300 & & & & \\
\hline & 2300 & 7) $G$ & & & 35 \\
\hline & 2300 & 0 & & & 000 \\
\hline & 2300 & 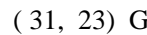 & & & \\
\hline & & & & & \\
\hline & & & & & \\
\hline & 2300 & & & & \\
\hline & 2300 & & E-05 & 376.000 & 3573 \\
\hline 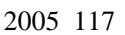 & & , & $.6366 \mathrm{E}-05$ & 78.000 & 573.00 \\
\hline
\end{tabular}


APRIL 28, 2005 CALPUFF CONCENTRATIONS FOR PM10 10 HOUR ACTIVITY DURATION

TOP-50 24 HOUR AVERAGE CONCENTRATION VALUES $\left(\mathrm{g} / \mathrm{m}^{* * 3}\right)$

\section{YEAR DAY TIME(HHMM) RECEPTOR TYPE CONCENTRATION COORDINATES (km)}

\begin{tabular}{|c|c|c|c|c|c|}
\hline & & 21) & & & \\
\hline 118 & 300 & $4,24) G$ & & & \\
\hline 18 & 300 & $7,32)$ & & & \\
\hline & 00 & $2,22) G$ & & & \\
\hline & 300 & & & & \\
\hline 05 & 300 & $14,23)$ & & & \\
\hline & 300 & 16, 27) & & & \\
\hline 05 & 2300 & $18,30) \mathrm{G}$ & & & \\
\hline 18 & 300 & $5,26) G$ & & & \\
\hline & 300 & & & & \\
\hline 18 & 300 & , 23) G & & & \\
\hline & 300 & & & & \\
\hline & 2300 & & & & \\
\hline & 300 & & & & \\
\hline 18 & 300 & & & & \\
\hline 18 & 300 & & & & \\
\hline & 300 & & & & \\
\hline 18 & 2300 & 1) $G$ & & & \\
\hline & 2300 & & & & \\
\hline & 2300 & & & & \\
\hline & 2300 & & & & \\
\hline & 300 & & & & \\
\hline 5118 & 2300 & 3) & & & \\
\hline 18 & 2300 & & & & \\
\hline 18 & 300 & & & & \\
\hline 18 & 2300 & U & & & \\
\hline & 2300 & & & & \\
\hline & 2300 & & & & \\
\hline & 2300 & & & & \\
\hline 18 & 2300 & & & & \\
\hline & 2300 & & & & \\
\hline 18 & 2300 & & & & \\
\hline & 2300 & J & & & \\
\hline & 2300 & & & & \\
\hline & 2300 & & & & \\
\hline & 2300 & & & & \\
\hline 18 & 2300 & 2) & & & \\
\hline & 300 & & & & \\
\hline & 2300 & S & & & \\
\hline & 2300 & & & & \\
\hline & 2300 & 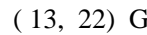 & & & \\
\hline & 2300 & & & & \\
\hline & 2300 & 3) & & & 358 \\
\hline & 2300 & 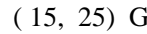 & & & 35 \\
\hline & 2300 & 3) $\mathrm{G}$ & & & \\
\hline & & & & & \\
\hline & & & & & \\
\hline & 2000 & & & & \\
\hline & 2300 & & E-05 & 398.000 & 3573.000 \\
\hline & & (12 & $.4036 \mathrm{E}-05$ & 374.000 & 565.00 \\
\hline
\end{tabular}


APRIL 29, 2005 CALPUFF CONCENTRATIONS FOR PM10 10 HOUR ACTIVITY DURATION

TOP-50 24 HOUR AVERAGE CONCENTRATION VALUES $\left(\mathrm{g} / \mathrm{m}^{* * 3}\right)$

\section{YEAR DAY TIME(HHMM) RECEPTOR TYPE CONCENTRATION COORDINATES (km)}

\begin{tabular}{|c|c|c|c|c|c|}
\hline & & 22) $\mathrm{G}$ & & & \\
\hline & 300 & $7,31) \mathrm{G}$ & & & \\
\hline 19 & 00 & $2,21)$ & & & \\
\hline & 00 & $3,23)$ & & & \\
\hline & 300 & & & & \\
\hline 05 & 300 & $15,26) \mathrm{G}$ & & & \\
\hline & 300 & $12,20)$ & & & \\
\hline 05 & 300 & $17,30) \mathrm{G}$ & & & \\
\hline & 300 & $4,25) G$ & & & \\
\hline & 300 & 6) $\mathrm{G}$ & & & \\
\hline & 300 & , 23) G & & & \\
\hline & 300 & (29) & & & \\
\hline 05 & 300 & , 29) $\mathrm{G}$ & & & \\
\hline & 300 & & & & \\
\hline & 2300 & & & & \\
\hline 19 & 300 & & & & \\
\hline & 300 & & & & \\
\hline & 300 & (0) G & & & \\
\hline & 2300 & & & & \\
\hline & 2300 & & & & \\
\hline & 2300 & & & & \\
\hline & 300 & & & & \\
\hline 19 & 2300 & 2) G & & & \\
\hline & 2300 & & & & \\
\hline & 300 & & & & \\
\hline & 300 & 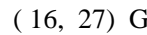 & & & \\
\hline & 2300 & & & & \\
\hline & 2300 & & & & \\
\hline & 2300 & & & & \\
\hline 19 & 2300 & 29) & & & \\
\hline & 2300 & & & & \\
\hline & 300 & & & & \\
\hline & 2300 & $G$ & & & \\
\hline & 2300 & & & & \\
\hline & 2300 & & & & \\
\hline & 2300 & 7) $\mathrm{G}$ & & & \\
\hline & 2300 & & & & \\
\hline & 00 & & & & \\
\hline & 0 & & & & \\
\hline & 2300 & & & & \\
\hline & 2300 & & & & \\
\hline & 2300 & & & & \\
\hline & 2300 & , 28) G & & & 000 \\
\hline & 2300 & & & & 35 \\
\hline & 2300 & ) & & & \\
\hline & & & & & \\
\hline & & & & & \\
\hline & 2300 & & & & \\
\hline & 2300 & 0 & 0E-05 & 410.000 & 609.000 \\
\hline 119 & & $(19,32)$ & $.2031 \mathrm{E}-05$ & 86.000 & 881.00 \\
\hline
\end{tabular}


APRIL 30, 2005 CALPUFF CONCENTRATIONS FOR PM10 10 HOUR ACTIVITY DURATION

TOP-50 24 HOUR AVERAGE CONCENTRATION VALUES $\left(\mathrm{g} / \mathrm{m}^{* * 3}\right)$

\section{YEAR DAY TIME(HHMM) RECEPTOR TYPE CONCENTRATION COORDINATES (km)}

\begin{tabular}{|c|c|c|c|c|}
\hline & & 4, 25) G & & 0 \\
\hline & & $1,22) \mathrm{G}$ & & 00 \\
\hline 20 & 300 & 7, 32) & & 00 \\
\hline & & לרם & & \\
\hline & 300 & 28) & & \\
\hline & 300 & $4,29)$ & & \\
\hline & 300 & $13,22)$ & & \\
\hline & 300 & $5,29) \mathrm{G}$ & & \\
\hline & 300 & 5) G & & \\
\hline & 300 & 26) $\mathrm{G}$ & & \\
\hline & 300 & & & \\
\hline & 2300 & $18,32) G$ & & \\
\hline & 300 & & & \\
\hline & 300 & & & \\
\hline & 300 & & & \\
\hline & 300 & & & \\
\hline & 300 & 6) $\mathrm{G}$ & & \\
\hline & 2300 & & & 003 \\
\hline & 2300 & & & \\
\hline & 2300 & & & 00 \\
\hline & 300 & & &  \\
\hline 20 & 2300 & & & 003 \\
\hline & 00 & & & \\
\hline & 300 & & & \\
\hline & 300 & & & 03 \\
\hline & 2300 & & & \\
\hline & 2300 & & & $0:$ \\
\hline & 0 & & & 00 \\
\hline 20 & 2300 & & & 035 \\
\hline & 2300 & & & \\
\hline & 2300 & & & \\
\hline & 300 & 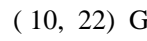 & & \\
\hline & 2300 & & & \\
\hline & 2300 & & & 00 \\
\hline & 2300 & & & 003 \\
\hline & & & & 03 \\
\hline 20 & 2300 & 27) $\mathrm{G}$ & & 0035 \\
\hline & 2300 & & & \\
\hline & 0 & & & \\
\hline & 2300 & & & 035 \\
\hline & 2300 & & & 0035 \\
\hline & 2300 & & & 00358 \\
\hline & & & & 0035 \\
\hline & 2300 & o) $u$ & & 0035 \\
\hline & & & & \\
\hline & & & & \\
\hline & 2300 & & & \\
\hline & 2300 & & & 376.000356 \\
\hline & 2300 & & 05 & 380.0003585 .000 \\
\hline 20 & 2300 & $(13,24)$ & $2.4066 \mathrm{E}-05$ & $374.000 \quad 3565.000$ \\
\hline
\end{tabular}


APRIL 25, 2005 CALPUFF CONCENTRATIONS FOR PM10 1 HOUR ACTIVITY DURATION

TOP-50 24 HOUR AVERAGE CONCENTRATION VALUES ( $\left.\mathrm{g} / \mathrm{m}^{* * 3}\right)$

YEAR DAY TIME(HHMM) RECEPTOR TYPE CONCENTRATION COORDINATES (km)

\begin{tabular}{|c|c|c|c|c|c|}
\hline 5 & - & $13,23) \mathrm{G}$ & & & \\
\hline 15 & 300 & 26) $\mathrm{G}$ & E-05 & & \\
\hline 15 & 300 & $12,22) G$ & & & \\
\hline 15 & 300 & $2,21) \mathrm{G}$ & & & \\
\hline & 300 & 31) G & & & \\
\hline & 300 & 26) $\mathrm{G}$ & & & \\
\hline & 300 & $16,26) \mathrm{G}$ & & & \\
\hline & 300 & $15,27) G$ & & 00 & 000 \\
\hline 15 & 300 & $14,23) G$ & & & \\
\hline 15 & 300 & $4,25) \mathrm{G}$ & & & \\
\hline & 300 & 9) G & & & \\
\hline & 300 & 7, 29) $\mathrm{G}$ & & & \\
\hline 15 & 2300 & 3, 29) G & & & \\
\hline & 2300 & , 20) G & & & \\
\hline 05 & 2300 & , 28) G & & & 000 \\
\hline & 300 & 30) G & & & \\
\hline 15 & 2300 & & & & \\
\hline 5 & 300 & 7) G & & & \\
\hline & 2300 & 33) G & & & \\
\hline 15 & 2300 & 0) G & & & \\
\hline & 2300 & $3,22) G$ & & & \\
\hline & 2300 & & & & \\
\hline & 2300 & 2) G & & & \\
\hline 15 & 2300 & & & & \\
\hline 5 & 300 & 2) & & & \\
\hline 5 & 2300 & & & & \\
\hline 5 & 2300 & 1) $G$ & & & \\
\hline 15 & 2300 & 1) $G$ & & & \\
\hline & 2300 & & & & \\
\hline 5 & 2300 & 8 & & & \\
\hline & 2300 & 1) & & & \\
\hline 15 & 2300 & $(14,27) \mathrm{G}$ & & & 35 \\
\hline & 2300 & 20) G & & & \\
\hline 5 & 2300 & 2) $G$ & & & \\
\hline & 2300 & 4) $G$ & & & \\
\hline & 2300 & & & & \\
\hline & 2300 & 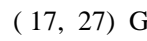 & & & \\
\hline & 2300 & $(15,23) \mathrm{G}$ & & & 35 \\
\hline & 2300 & $0,20)$ & & & 35 \\
\hline 15 & 2300 & 3) $\mathrm{G}$ & & & 000 \\
\hline & 2300 & ? & & & \\
\hline & 2300 & & & & \\
\hline & 2300 & & & & \\
\hline & 2300 &  & & & 000 \\
\hline & 2300 & $(14,28) G$ & & 376 & 3573.000 \\
\hline & 2300 & & & & 000 \\
\hline & 2300 & & & 37 & 000 \\
\hline & & & & & \\
\hline & & & & & \\
\hline & & & $.6767 \mathrm{E}-05$ & 380.000 & 3567.00 \\
\hline
\end{tabular}


APRIL 26, 2005 CALPUFF CONCENTRATIONS FOR PM10 1 HOUR ACTIVITY DURATION

TOP-50 24 HOUR AVERAGE CONCENTRATION VALUES ( $\left.\mathrm{g} / \mathrm{m}^{* * 3}\right)$

\section{YEAR DAY TIME(HHMM) RECEPTOR TYPE CONCENTRATION COORDINATES (km)}

$20051162300 \quad(15,26) \mathrm{G} \quad 8.4935 \mathrm{E}-05 \quad 378.0003569 .000$

$20051162300 \quad(14,23)$ G $\quad 7.3991 \mathrm{E}-05 \quad 376.0003563 .000$

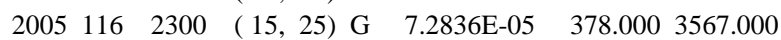



$20051162300 \quad(16,26)$ G $\quad 6.7645 \mathrm{E}-05 \quad 380.0003569 .000$

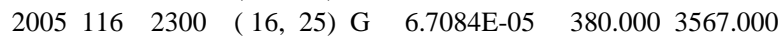

$20051162300 \quad(15,23)$ G $\quad 6.6891 \mathrm{E}-05 \quad 378.0003563 .000$

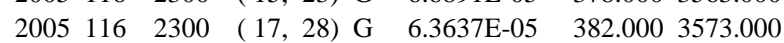

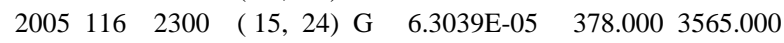

$20051162300 \quad(16,28)$ G $\quad 6.1990 \mathrm{E}-05 \quad 380.0003573 .000$

$20051162300 \quad(15,28)$ G $\quad 6.1860 \mathrm{E}-05 \quad 378.0003573 .000$

$20051162300 \quad(14,27)$ G $\quad 6.0755 \mathrm{E}-05 \quad 376.000 \quad 3571.000$

$20051162300 \quad(16,27) G \quad 5.8687 \mathrm{E}-05 \quad 380.0003571 .000$

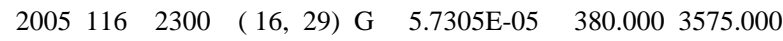

$20051162300 \quad(14,25)$ G $\quad 5.7025 \mathrm{E}-05 \quad 376.0003567 .000$



$20051162300 \quad(15,27)$ G $\quad 5.6520 \mathrm{E}-05 \quad 378.0003571 .000$

$20051162300 \quad(14,26)$ G $\quad 5.5437 \mathrm{E}-05 \quad 376.0003569 .000$

$20051162300 \quad(13,24)$ G $\quad 5.5123 \mathrm{E}-05 \quad 374.0003565 .000$

$20051162300 \quad(14,24)$ G $\quad 5.4130 \mathrm{E}-05 \quad 376.0003565 .000$

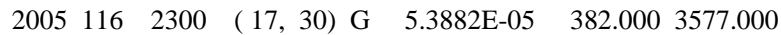

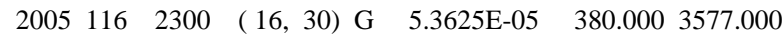

$20051162300 \quad(15,30) G \quad 5.2235 E-05 \quad 378.0003577 .000$



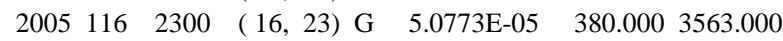

$20051162300 \quad(16,24)$ G $\quad 4.9706 \mathrm{E}-05 \quad 380.0003565 .000$

$20051162300 \quad(16,31) G \quad 4.9098 \mathrm{E}-05 \quad 380.000 \quad 3579.000$

$2005116 \quad 2300 \quad(12,22) \mathrm{G} \quad 4.8995 \mathrm{E}-05 \quad 372.0003561 .000$

$20051162300 \quad(15,29)$ G $\quad 4.8884 \mathrm{E}-05 \quad 378.0003575 .000$

$20051162300 \quad(14,22) G \quad 4.8205 \mathrm{E}-05 \quad 376.0003561 .000$

$20051162300 \quad(15,31) \mathrm{G} \quad 4.7171 \mathrm{E}-05 \quad 378.000 \quad 3579.000$

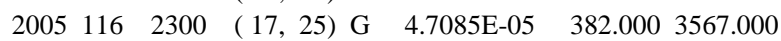

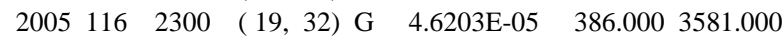

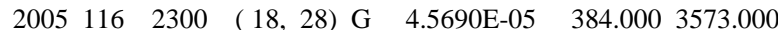

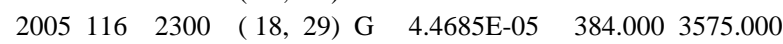

$20051162300 \quad(18,30)$ G $\quad 4.4399 \mathrm{E}-05 \quad 384.0003577 .000$

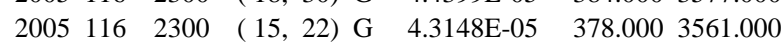

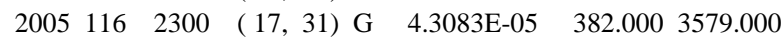

$20051162300 \quad(18,31) \mathrm{G} \quad 4.2717 \mathrm{E}-05 \quad 384.0003579 .000$



$20051162300 \quad(17,26)$ G $\quad 4.1918 \mathrm{E}-05 \quad 382.0003569 .000$

$20051162300 \quad(16,22) \mathrm{G} \quad 4.1860 \mathrm{E}-05 \quad 380.0003561 .000$



$20051162300 \quad(12,21) \mathrm{G} \quad 4.0887 \mathrm{E}-05 \quad 372.0003559 .000$

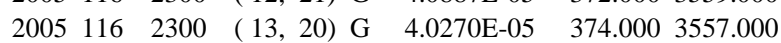

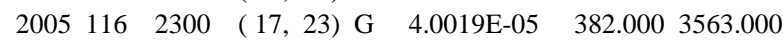

$20051162300 \quad(13,21) G \quad 3.9782 \mathrm{E}-05 \quad 374.0003559 .000$

$20051162300 \quad(13,22)$ G $\quad 3.9078 \mathrm{E}-05 \quad 374.0003561 .000$

$2005116 \quad 2300 \quad(12,20)$ G $\quad 3.7902 \mathrm{E}-05 \quad 372.0003557 .000$

$20051162300 \quad(18,27) G \quad 3.7795 E-05 \quad 384.0003571 .000$ 
APRIL 27, 2005 CALPUFF CONCENTRATIONS FOR PM10 1 HOUR ACTIVITY DURATION

TOP-50 24 HOUR AVERAGE CONCENTRATION VALUES ( $\left.\mathrm{g} / \mathrm{m}^{* * 3}\right)$

YEAR DAY TIME(HHMM) RECEPTOR TYPE CONCENTRATION COORDINATES (km)

\begin{tabular}{|c|c|c|c|c|c|c|}
\hline & & 300 & $13,28) G$ & & & \\
\hline & & 300 & $13,25) G$ & $6.0584 \mathrm{E}-05$ & & \\
\hline & 17 & 300 & $12,25) G$ & & & \\
\hline & 17 & 300 & $7,32) \mathrm{G}$ & & & \\
\hline & 17 & 300 & $6,32)$ & & & \\
\hline & 7 & 300 & 28) $G$ & & & \\
\hline & 7 & 300 & $15,32)$ & & & \\
\hline & 7 & 300 & $15,29) \mathrm{G}$ & & & 000 \\
\hline & 17 & 300 & $14,29) G$ & & & 000 \\
\hline & 17 & 300 & $16,29) \mathrm{G}$ & & & \\
\hline & 17 & 300 & 27) $G$ & & & \\
\hline & 117 & 300 & 30) G & & & \\
\hline & 17 & 2300 & $3,26) G$ & & & \\
\hline & 7 & 2300 & & & & \\
\hline & 17 & 2300 & 26) $\mathrm{G}$ & & & 000 \\
\hline & 17 & 300 & 30) & & & \\
\hline & 117 & 2300 & & & & 00 \\
\hline & 17 & 300 & 32) $G$ & & & \\
\hline & 17 & 2300 & 27) $\mathrm{G}$ & & & \\
\hline & 117 & 2300 & 31) $G$ & & & \\
\hline & 7 & 2300 & & & & \\
\hline & 17 & 2300 & & & & \\
\hline & 17 & 2300 & 3) $G$ & & & \\
\hline & 17 & 2300 & & & & 000 \\
\hline & 7 & 300 & 8) & & & \\
\hline & 17 & 2300 & 5) $\mathrm{G}$ & & & \\
\hline & 17 & 2300 & 1) $G$ & & & \\
\hline & 17 & 2300 & 9) $\mathrm{G}$ & & & \\
\hline & 17 & 2300 & & & & \\
\hline & 7 & 2300 & (1) & & & \\
\hline & & 2300 &  & & & \\
\hline & 117 & 2300 & 17 & & & 35 \\
\hline & 17 & 2300 & & & & \\
\hline & 17 & 2300 & S & & & \\
\hline & 17 & 2300 & G & & & \\
\hline & 17 & 2300 & 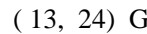 & & & \\
\hline & 17 & 2300 & $(12,24)$ & & & \\
\hline & 117 & 2300 & $(14,23) G$ & & & 35 \\
\hline & 117 & 2300 & $\Rightarrow$ & & & 358 \\
\hline & 117 & 2300 & ) $u$ & & & 000 \\
\hline & 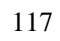 & 2300 & & & & \\
\hline & 117 & 2300 & a) & & & \\
\hline & 17 & 2300 & & & & \\
\hline & 117 & 2300 & 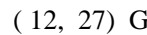 & & & 000 \\
\hline & 17 & 2300 & $(13,23) \mathrm{G}$ & & 37 & .000 \\
\hline & & 2300 & & & 37 & 000 \\
\hline & & 2300 & & & & 000 \\
\hline & & & & & & \\
\hline & & & & & & \\
\hline & 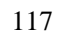 & & & 2 & (200 & 3583.00 \\
\hline
\end{tabular}


APRIL 28, 2005 CALPUFF CONCENTRATIONS FOR PM10 1 HOUR ACTIVITY DURATION

TOP-50 24 HOUR AVERAGE CONCENTRATION VALUES ( $\left.\mathrm{g} / \mathrm{m}^{* * 3}\right)$

\section{YEAR DAY TIME(HHMM) RECEPTOR TYPE CONCENTRATION COORDINATES (km)}

\begin{tabular}{|c|c|c|c|c|c|}
\hline & & 26) $G$ & & & \\
\hline 118 & 300 & $5,27)$ & & & \\
\hline 18 & 00 & 23) & & & \\
\hline & 00 & 4) $G$ & & & \\
\hline & 300 & (2) & & & \\
\hline 05 & 300 & $6,26) \mathrm{G}$ & & & \\
\hline & 300 & 24) & & & \\
\hline 05 & 2300 & 26) $\mathrm{G}$ & & & \\
\hline 18 & 300 & $6,27) \mathrm{G}$ & & & \\
\hline & 300 & & & & \\
\hline 18 & 300 & 23) G & & & \\
\hline & 300 & (25) & & & \\
\hline & 2300 & , 20) G & & & \\
\hline & 2300 & $12,23) \mathrm{G}$ & & & \\
\hline & 2300 & & & & \\
\hline 18 & 300 & & & & \\
\hline & 300 & 2) & & & \\
\hline 18 & 2300 & 23) G & & & \\
\hline & 2300 & & & & \\
\hline & 2300 & & & & \\
\hline & 2300 & & & & \\
\hline & 300 & & & & \\
\hline 5118 & 2300 & 28) $G$ & 55 & & \\
\hline 18 & 2300 & & & & \\
\hline 18 & 2300 & & & & \\
\hline 18 & 2300 & G & & & \\
\hline & 2300 & & & & \\
\hline & 2300 & & & & \\
\hline & 2300 & & & & \\
\hline 18 & 2300 & & & & \\
\hline & 2300 & & & & \\
\hline 18 & 2300 & & & & \\
\hline 18 & 2300 & (7) & & & \\
\hline & 2300 & & & & \\
\hline & 2300 & & & & \\
\hline & 2300 & ( & & & \\
\hline & 2300 & & & & \\
\hline & 300 & & & & \\
\hline & 00 & & & & \\
\hline & 2300 & & & & \\
\hline & 2300 & & & & \\
\hline & 2300 & & & & \\
\hline & 2300 & & & & .000 \\
\hline & 2300 & & 05 & & 000 \\
\hline & 2300 & & & & \\
\hline & & & & & \\
\hline & & & & & \\
\hline & 2000 & & & & \\
\hline & 2300 & & 5E-05 & 380.000 & 000 \\
\hline & & ( & $2563 \mathrm{E}-05$ & 76.000 & 559.00 \\
\hline
\end{tabular}


APRIL 29, 2005 CALPUFF CONCENTRATIONS FOR PM10 1 HOUR ACTIVITY DURATION

TOP-50 24 HOUR AVERAGE CONCENTRATION VALUES ( $\left.\mathrm{g} / \mathrm{m}^{* * 3}\right)$

YEAR DAY TIME(HHMM) RECEPTOR TYPE CONCENTRATION COORDINATES (km)

\begin{tabular}{|c|c|c|c|c|c|c|}
\hline & & 00 & 29) $\mathrm{G}$ & & & \\
\hline & & & 24) & & & \\
\hline & & 0 & 22) & & & \\
\hline & & 00 & & & & \\
\hline & & 00 & & & & \\
\hline  & & 300 & & & & \\
\hline 05 & 9 & 00 & & & & \\
\hline 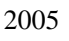 & & 300 & , 25) G & & & \\
\hline & & 300 & & & & \\
\hline 5 & & 00 & (7) & & & \\
\hline 05 & & 300 & & & & \\
\hline 5 & & 300 & 32) & & & \\
\hline D & & 300 & & & & \\
\hline ; & & 300 & & & & \\
\hline 0 & & 300 & 28) & & & \\
\hline & & 00 & & & & \\
\hline & & 00 & 28) & & & \\
\hline & & 300 & & & & \\
\hline 5 & & 300 & & & & \\
\hline & & 300 & & & & \\
\hline 0 & & 300 & & & & \\
\hline 0 & & 00 & & & & \\
\hline 0 & & 300 & & & & \\
\hline & & 300 & & & & \\
\hline 5 & & 00 & & & & \\
\hline & & 00 & & & & \\
\hline & & 300 & & & & \\
\hline & & & & & & \\
\hline 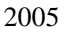 & & & 27) & & & \\
\hline 0 & & 300 & & & & \\
\hline & & 0 & & & & \\
\hline & & 0 & & & & \\
\hline 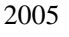 & & & & & & \\
\hline 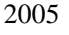 & & 300 & & & & \\
\hline & & & & & & \\
\hline 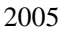 & & 2300 & & & & \\
\hline & & & & & & \\
\hline & & & & & & \\
\hline & & 0 & & & & \\
\hline 5 & & & & & & \\
\hline 005 & & 00 & & & & \\
\hline & & & & & & \\
\hline 0 & & 00 & & & & \\
\hline & & & & & & \\
\hline & & & & & & \\
\hline & & 2300 & & & & \\
\hline & & 2300 & , 23) & & & 356 \\
\hline 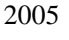 & & 200 & & -05 & $\pi$ & .000 \\
\hline & & & 23) & $5 E-05$ & 00 & \\
\hline 00 & & 300 & $14,7)$ & $1.6946 \mathrm{E}-05$ & 6000 & 3531.000 \\
\hline
\end{tabular}


APRIL 30, 2005 CALPUFF CONCENTRATIONS FOR PM10 1 HOUR ACTIVITY DURATION

TOP-50 24 HOUR AVERAGE CONCENTRATION VALUES ( $\left.\mathrm{g} / \mathrm{m}^{* * 3}\right)$

\section{YEAR DAY TIME(HHMM) RECEPTOR TYPE CONCENTRATION COORDINATES (km)}

\begin{tabular}{|c|c|c|c|c|c|}
\hline & & 23) G & & & \\
\hline & 300 & $12,24) \mathrm{G}$ & & & \\
\hline & 00 & $1,22)$ & & & \\
\hline & 00 & $2,23)$ & & & \\
\hline & 00 & 23) & & & \\
\hline & 300 & $12,22) G$ & & & \\
\hline & 300 & $0,22) \mathrm{G}$ & & & \\
\hline 05 & 300 & $12,21) \mathrm{G}$ & & & \\
\hline & 300 & $11,21) \mathrm{G}$ & & & \\
\hline & 300 & 2) G & & & \\
\hline & 300 & , 23) G & & & \\
\hline & 300 & & & & \\
\hline & 300 & & & & \\
\hline & 300 & & & & \\
\hline & 300 & 21) & & & \\
\hline & 300 & & & & \\
\hline & 300 & & & & \\
\hline & 300 & 5) G & & & \\
\hline & 2300 & & & & \\
\hline & 2300 & & & & \\
\hline & 2300 & & & & \\
\hline & 300 & & & & \\
\hline 5120 & 2300 & 20) & & & \\
\hline & 2300 & & & & \\
\hline & 300 & 8) $\mathrm{G}$ & & & \\
\hline & 2300 & 7) $\mathrm{G}$ & & & \\
\hline & 2300 & & & & \\
\hline & 2300 & & & & \\
\hline & 2300 & c) & & & \\
\hline 20 & 2300 & 0) G & & & 00 \\
\hline & 2300 & & & & \\
\hline 20 & 2300 & & & & \\
\hline & 300 & 3) $\mathrm{G}$ & & & \\
\hline & 2300 & & & & \\
\hline & 2300 & & & & \\
\hline & 2300 & G & & & \\
\hline & 2300 & 0) $\mathrm{G}$ & & & \\
\hline & 00 & & & & \\
\hline & 00 & 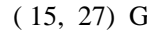 & & & \\
\hline & 2300 & & & & \\
\hline & 2300 & 9) $\mathrm{G}$ & & & \\
\hline & 2300 & & & & \\
\hline & 2300 & & & & \\
\hline & 2300 & & & & 000 \\
\hline & 2300 & 9) $\mathrm{G}$ & & & \\
\hline & & & & & \\
\hline & & & & & \\
\hline & 2000 & & & & \\
\hline & 2300 & & -05 & 370.000 & 3567 \\
\hline & & & $1 \mathrm{E}-05$ & 78.000 & 669.00 \\
\hline
\end{tabular}


PNNL-15935

\section{Distribution}

No. of

Copies

OFFSITE

2 Jesus D. Moncada

Fort Bliss, Directorate of Environment

IMSW-BLS Attn: Moncada

Bldg. 622-South, Taylor Road

Fort Bliss, Texas 79916

(915) 568-1838
No. of

Copies

\section{ONSITE}

8 Pacific Northwest National Laboratory

K. J. Allwine

K9-30

E. G. Chapman

K9-30

R. K. Newsom

K9-30

J. P. Rishel

K9-30

F. C. Rutz

K6-52

T. E. Seiple

K6-52

Information Release (2)

P8-55

Distr. 1 